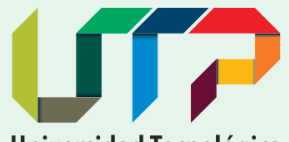

Universidad Tecnológica de Pereira

Facultad

Ciencias de la Educación

\title{
Modos de Ver III: \\ Los sentidos de la Comunicación Educativa
}

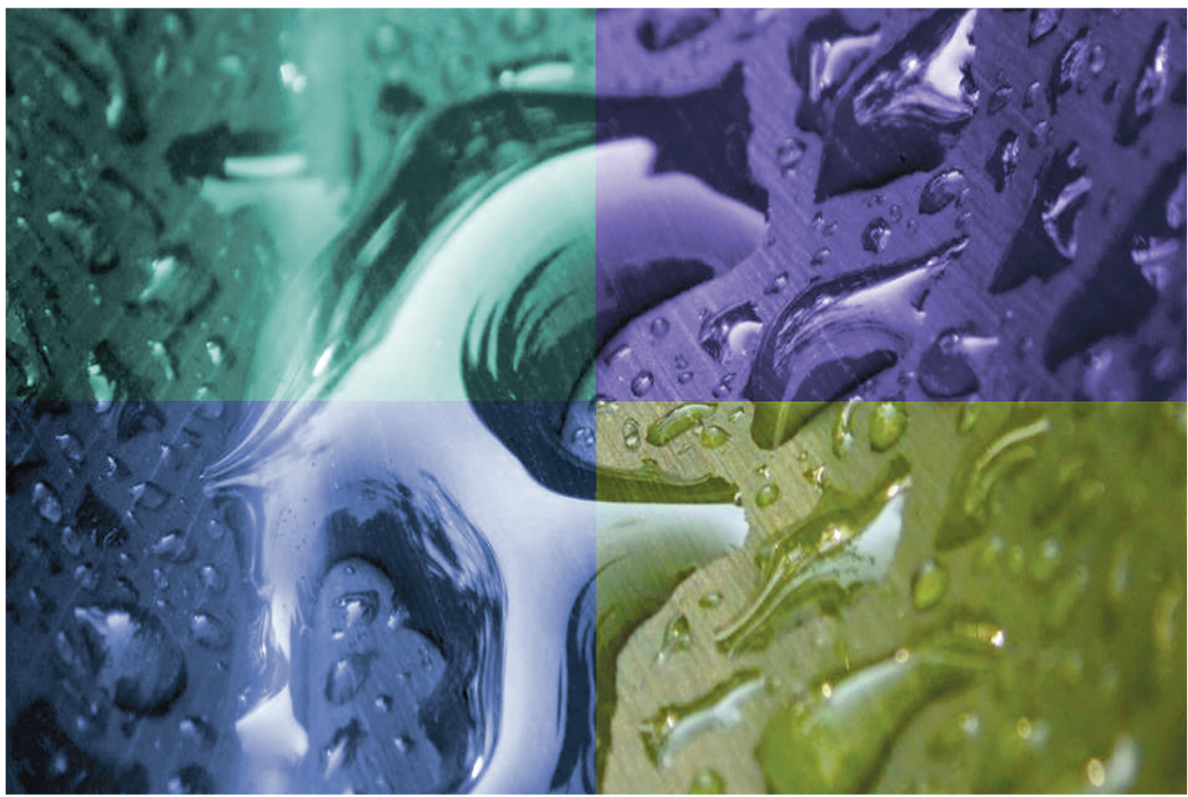

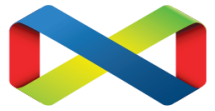

Editorial UTP
Olga Lucía Bedoya Julián David Vélez Carvajal Victoria Eugenia Valencia López 
Olga Lucía Bedoya (Medellín, Antioquia, Colombia, 1963). Doctora en Ciencias Políticas de la Universidad Santiago de Compostela, España. Magister en Lingüística y Antropóloga de la Universidad de Antioquia. Docente titular de la Facultad de Ciencias de la Educación de la Universidad Tecnológica de Pereira. Premio de Investigación Jorge Roa Martínez (segundo puesto).

Autora de los libros: Pereira Imaginada (2011), La Construcción de Ciudad: una mirada comunicativa (2009), Pereira Post - sísmica 2001 - 2006: otras Cartografías desde la Percepción Ciudadana (2008), El ciudadano y sus múltiples voces: un Imaginario Actual - Potencial (2005), Modos de Ver II: Los sentidos de la Comunicación Educativa (2008), Paradoja de la Ciudadanía en Pereira: entre los Ciudadanos Jurídico - políticos y los Itinerantes (2004), Modos de Ver I: Los Sentidos de la Comunicación Educativa (2002), Imaginario Femenino y Ciudad: Pereira y su Evocación de Mujer (1999).

Ha publicado artículos en revistas especializadas nacionales e internacionales.

Directora del grupo de Investigación en Comunicación Educativa.

olbedoya@utp.edu.co

Julián David Vélez Carvajal (Pereira, Risaralda, Colombia 1981). Doctor en Ciencias de la Educación de la Universidad Tecnológica de Pereira, Magister en Comunicación Educativa y Licenciado en Etnoeducación y Desarrollo Comunitario de la Universidad Tecnológica de Pereira. Docente transitorio de la Facultad de Ciencias de la Educación de la Universidad Tecnológica de Pereira.

Ha publicado artículos en revistas especializadas de carácter nacional e internacional.

Pertenece al grupo de investigación en Comunicación Educativa.

jvel@utp.edu.co

Victoria Eugenia López (Pereira, Risaralda, Colombia 1980). Doctora en Ciencias de la Educación de la Universidad Tecnológica de Pereira, Licenciada en Etnoeducación y Desarrollo Comunitario de la Universidad Tecnológica de Pereira.

Coautora del libro: Pereira Post - sísmica 2001 - 2006: otras Cartografías desde la Percepción Ciudadana (2008). Ha publicado artículos en revistas especializadas de carácter nacional e internacional.

Pertenece al grupo de investigación en Comunicación Educativa.

vieval81@gmail.com 


\section{Modos de Ver III: \\ Los sentidos de la Comunicación Educativa}

Julián David Vélez Carvajal

Olga Lucía Bedoya

Victoria Eugenia Valencia López

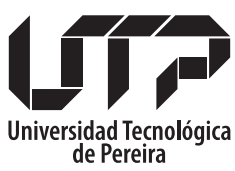

Colección Textos Académicos

Facultad de Ciencias de la Educación

Año 2016 
Bedoya, Olga Lucía

Modos de ver III : los sentidos de la comunicación educativa / Olga Lucía Bedoya, Julián David Vélez Carvajal y Victoria Eugenia Valencia López. Pereira : Editorial Universidad Tecnológica de Pereira, 2016.

87 páginas. - (Colección Textos Académicos)

ISBN: 978-958-722-250-0

1. Comunicación - Aspectos sociales 2. Medios de comunicación de masas 3. Tecnología educativa 4. Comunicación educativa 5. Antropología social

CDD. 302.23

(C) Julián David Vélez Carvajal, 2016

(C) Olga Lucía Bedoya, 2016

(C) Victoria Eugenia Valencia López, 2016

(C) Universidad Tecnológica de Pereira

Primera edición

Universidad Tecnológica de Pereira

Pereira, Colombia

Este libro fue evaluado por dos pares académicos de Colciencias.

Texto Académico

Universidad Tecnológica de Pereira

Vicerrectoría de Investigaciones, Innovación y Extensión

Editorial Universidad Tecnológica de Pereira

Coordinador editorial:

Luis Miguel Vargas Valencia

luismvargas@utp.edu.co

Teléfono +576 3137381

Edificio 9 Biblioteca Central Jorge Roa Martínez 9/N1/110

Cra 27 No 10 - 02 -Álamos

Pereira - Risaralda - Colombia

www.utp.edu.co

Montaje y producción:

Recursos Informáticos y Educativos

Diseño Gráfico

Universidad Tecnológica de Pereira 


\section{CONTENIDO}

Introducción. Perspectivas de la Comunicación Educativa

¿Cómo educa lo que comunicamos?............................................................. 5

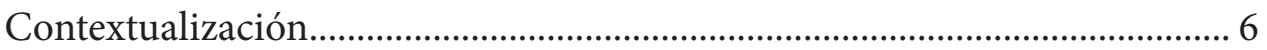

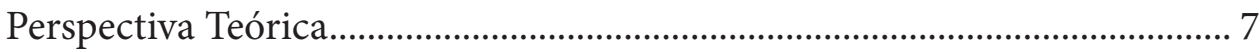

Puesta en escena de la perspectiva semiótico

- antropológica y sistémica.

Capítulo 1

Línea de investigación: La educación en los medios

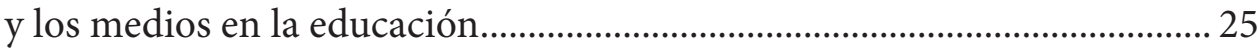

La educación en los medios y los medios en la educación ............................. 25

Capítulo 2

Línea de investigación: La comunicación y la educación

en los procesos de transformación cultural

La comunicación y la educación en los procesos

de transformación cultural.

Capítulo 3 95

Línea de investigación: Nuevas Tecnologías para la Educación.................... 97

Nuevas Tecnologías para la educación .....................................................97

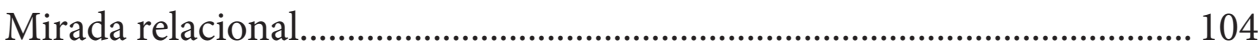

Esquema de observación 1: Perspectivas teóricas elegidas ......................... 107

Esquema de Observación 2. Perspectivas metodológicas implicadas ....... 110

Esquema de observación 3. Objetos de estudio seleccionados ................... 111

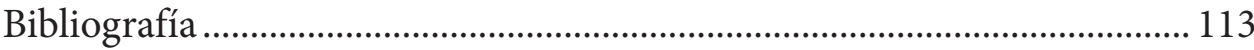





\section{Introducción.}

\section{Perspectivas de la Comunicación Educativa ¿Cómo educa lo que comunicamos?}

¿Cómo educa lo que comunicamos? ¿Es la explicitud de la intencionalidad educativa una condición sine qua non para el reconocimiento del carácter educativo de cualquier fenómeno social?, o ¿todos los fenómenos sociales son susceptibles de educar independientemente de que haya, o no, intencionalidad educativa? Al realizar un seguimiento a las investigaciones llevadas a cabo por los estudiantes de la Maestría en Comunicación Educativa de la Universidad Tecnológica de Pereira, se constata que uno de los aportes significativos que se hacen al campo de la relación comunicación - educación, desde este programa de formación, consiste en entender la educación como un proceso comunicativo que va más allá de lo que sucede en las aulas tradicionales.

Las tres líneas de investigación de la Maestría en Comunicación Educativa ${ }^{1}$, se constituyen en el horizonte temático que posibilita la realización de diversos trabajos de investigación con el propósito de dar respuesta a los interrogantes sugeridos en el párrafo precedente. En esta ocasión, presentamos a la comunidad académica "Modos de Ver III. Los sentidos de la Comunicación Educativa", libro en el que se da cuenta de las diferentes aproximaciones investigativas por parte de los estudiantes de este postgrado, en el marco de la realización de su trabajo de grado, durante el periodo de tiempo 2008- 2014.

Como consecuencia de este ejercicio, podemos aventurar una posible respuesta a los interrogantes planteados al inicio de este texto. La educación, como fenómeno comunicativo, en su sentido más amplio, no se asocia solamente a procesos de aula de tipo formal que se caracterizan por tener una intencionalidad explícita; sino que contiene múltiples escenarios que van desde lo urbano, pasando por la escuela, hasta llegar a las pantallas.

1 Las líneas de investigación de la Maestría en Comunicación Educativa son las siguientes: 1) La educación en los medios y los medios en la educación; 2) La comunicación y la educación en los procesos de transformación cultural; 3) Nuevas tecnologías para la educación. 
De allí que el esquema de referencia del que parte la Maestría en mención para comprender el campo de conocimiento denominado comunicación educativa, tenga como punto de partida la pregunta por lo que entraña la educación en relación de continuidad con la comunicación y la cultura.

No obstante, sugerimos que sea el lector quien construya sus propias respuestas a partir de las discusiones que se plantean en este documento. Por lo pronto, precisamos ofrecer un marco contextual sobre las prácticas investigativas realizadas al interior de este programa de formación, de tal manera que nuestros interlocutores construyan un marco de referencia que les permita la comprensión de lo que aquí se presenta.

\section{Contextualización}

La Maestría en Comunicación Educativa, es un programa de formación post - gradual adscrito a la Facultad de Ciencias de la Educación de la Universidad Tecnológica de Pereira. Desde su creación y formalización a partir del acuerdo 228 de 1986, ha hecho énfasis en la formación para la investigación. En este sentido, está planteada su misión:

Formar investigadores provenientes de diversas disciplinas interesadas en diseñar, desarrollar e implementar proyectos en comunicación educativa que respondan a las necesidades locales, regionales y nacionales; aplicando los aportes teóricos y tecnológicos de la información y la comunicación para responder a nuevas demandas y espacios educativos, asumiendo diferentes modos y usos de lo comunicativo expresados desde la cultura ${ }^{2}$.

Por tanto, durante sus 29 años de existencia ha consolidado tres líneas de investigación que fungen como fuente de inspiración para la toma de decisiones de tipo teórico-metodológico tanto para los proyectos generales de investigación, como para los trabajos de grado de los estudiantes. Las siguientes son las líneas de investigación:

- La comunicación y la educación en los procesos de transformación cultural: ciudad y comunicación.

\footnotetext{
Documento: Proyecto Educativo de la Maestría en Comunicación Educativa.
} 
- La educación en los medios y los medios en la educación.

- Nuevas tecnologías para la educación.

Las tres líneas antes mencionadas actualizan el objeto de estudio del área del conocimiento emergente denominada comunicación educativa; esto se ve reflejado en la visión del programa que plantea en su proyecto educativo lo siguiente: "desarrollar una pedagogía de la comunicación que conlleve a reconocer y asumir otros discursos sociales que promuevan a la educación como un espacio abierto a la cultura"3. En este contexto se crea el Grupo de Investigación en Comunicación Educativa - GICE - con el objetivo de retroalimentar no solo las ya referidas líneas de la Maestría, sino la correspondiente al área de Comunicación y Cultura que se encuentra adscrita al Doctorado en Ciencias de la Educación, área Pensamiento Educativo y Comunicación, ofertado por la Red de Universidades de Colombia RUDECOLOMBIA -, con sede en la Universidad Tecnológica de Pereira.

Este grupo tiene una trayectoria de más de doce años y, al momento, es reconocido por COLCIENCIAS en categoría B. Seguidamente, se procederá a referir la perspectiva teórica que transversaliza el ejercicio investigativo en el marco de la Maestría en Comunicación Educativa, con el propósito de contextualizar el contenido de este libro.

\section{Perspectiva Teórica}

La comunicación educativa se ha caracterizado por su enfoque inter y transdisciplinar. Disciplinas como la antropología, la sociología, la pedagogía, la semiótica, entre otras, han contribuido a la consolidación de este campo de conocimiento tanto en sus perspectivas teóricas y metodológicas, como en los objetos disciplinares correspondientes. En el marco de este escenario, podemos referir diferentes acercamientos a la relación comunicación educación que, no obstante tener algunas diferencias, comparten el rasgo común de abordar los fenómenos educativos como procesos comunicativos que van más allá del espacio de aula tradicional.

Documento: Proyecto Educativo de la Maestría en Comunicación Educativa. 
Uno de los referentes de este campo del conocimiento, han sido los estudios culturales que se han desarrollado en Europa, específicamente, en el Reino Unido. Este tipo de estudios reivindican los procesos culturares que suceden en el ámbito de la vida cotidiana como escenarios posibles para la consolidación de reivindicaciones de tipo social, político y económico por parte de sus integrantes. Si bien la cultura puede ser un espacio prolífero para la alienación de las masas, se constituye, también, en un mundo de posibilidades para la generación de dinámicas que dan sentido a la vida cotidiana (Thompson, 1998)

Valorar los procesos culturales que se dan en el ámbito de la vida cotidiana como escenarios válidos para la construcción de sentidos y de emancipaciones culturales ha sido el aporte que han realizado los estudios culturales a la comunicación educativa. Sugieren, entonces, que lo que gira alrededor de la vida cotidiana: ciudad, barrio, medios de comunicación, etc., podría contribuir a la transformación de la educación, tomando como base la relación entre esta y la comunicación.

La media Literacy (alfabetización en medios), plantea la importancia de generar procesos de alfabetización en medios de comunicación para la consolidación del ejercicio ciudadano; su objetivo no se limita a la perspectiva instrumental, por lo que se da relevancia a los procesos de recepción y creación de nuevos escenarios. Su aporte a la comunicación educativa, consiste en la actualización de la relación medios de comunicación - ciudadanía, en la que la recepción desempeña un papel de trascendencia.

Por otro lado, la importancia de generar un pensamiento propio que se proyecte al mundo y que tenga como premisa la emancipación del sujeto, es lo que impulsa a los intelectuales de América Latina a consolidar una escuela de pensamiento que articule la relación comunicación - educación. Los planteamientos sobre la pedagogía de la liberación del brasilero Paulo Freire se constituyen en la fuente de inspiración fundamental de esta corriente latinoamericana. La idea de construir propuestas contra - hegemónicas desde la América Latina se constituye en el objetivo fundamental. En el ámbito de la educación, esto implica, abstraerla de su orientación "bancaria" y "alienante" para proyectarla como un escenario de emancipación individual y colectiva; para este propósito es imprescindible articular la educación con la comunicación, lo cual significa volcarla sobre la realidad en aras de transformarla. 
Con variaciones que permiten entrever importantes diferencias, se han desarrollado sucesivas experiencias en el ámbito latinoamericano; tal es el caso del colombo - español Jesús Martín Barbero, quien introduce la discusión sobre lo simbólico, las mediaciones y lo urbano con el propósito de consolidar una línea de pensamiento en el ámbito de la comunicación educativa con una fuerte impronta latinoamericana.

En el marco de la primera década del siglo XXI, se ha realizado un reencuentro de los planteamientos de los que, otrora, en el siglo XX, habían sentado las bases de la consolidación de la comunicación educativa con unas características propias de la subregión latinoamericana. Esta reunificación se hace con el objetivo de articular la reflexión que se ha realizado sobre la comunicación educativa con las dinámicas socio - culturales contemporáneas. Específicamente, se trata de reflexionar sobre las implicaciones que trae consigo la popularización de internet, particularmente, los procesos de comunicación emergentes a la denominada web 2.0. Al parecer hay consenso en la necesidad de actualizar los planteamientos de la pedagogía de la liberación como el pilar sobre el cual se desarrollaría un pensamiento autóctono en este campo.

En síntesis, el reconocimiento de la vida cotidiana como escenario para las reivindicaciones sociales (Estudios Culturales), la alfabetización en medios para la recepción y la ciudadanía (Media Literacy), y la necesidad de la generación de un pensamiento propio basado en la pedagogía de la liberación (perspectiva latinoamericana); han sido tópicos que han alimentado a la Maestría en Comunicación Educativa y a su grupo de investigación. No obstante, inspirados en la relación de recursividad entre teoría y práctica y en la posibilidad de construir marcos interpretativos basados en los teóricos de base, el Grupo de investigación de la Maestría ha procurado la emergencia de otra perspectiva que al conservar los mismos objetos de reflexión y establecer relaciones de continuidad con lo desarrollado anteriormente, ha consolidado un escenario de acción propio que es necesario referir.

La construcción de ingenios discursivos que susciten la idea de los mundos posibles y de lo contingente; así como la superación de cualquier tipo de compartimentación del conocimiento basada en criterios culturales, nacionalistas o geográficos han sido los dos pilares que han inspirado el marco interpretativo al interior de la Maestría en Comunicación Educativa de la Universidad Tecnológica de Pereira. La ciudadanía universal es, entonces, el 
criterio de distinción. En este sentido, han sido varios los referentes teóricos que han alimentado esta perspectiva que hemos denominado semiótica, antropológica y sistémica.

El componente semiótico - antropológico aborda las dinámicas contemporáneas como procesos culturales que fungen desde la comunicación. Esta última se adscribe en un sentido amplio, por lo que su acepción incluye los medios masivos, pero va más allá de ellos. Todas las manifestaciones simbólicas de los seres humanos, bien sea desde los dispositivos oral, lecto - escritural o digital, se articulan como objeto de reflexión desde la comunicación. De allí la importancia del componente semiótico, pues una acepción tal de la comunicación, implica suscribir que el acercamiento que hacemos los seres humanos al mundo, en tanto construcción de realidad, se hace desde la interpretación sígnica.

La lógica de relativos, la teoría de las categorías del ser, así como la teoría del signo desarrolladas por el filósofo norteamericano Charles Sanders Peirce, se constituyen en el sustento filosófico de este componente. Aporta en el abordaje de la realidad desde el punto de vista tríadico y en la concepción de los procesos de razonamiento como lógicas de interpretación del mundo a partir de signos. Trasciende las perspectivas del deber ser.

En concomitancia con el referente teórico ya descrito, se realizan acercamientos a las construcciones teórico - metodológicas de investigadores como Armando Silva Téllez, Néstor García Canclini, Guillermo Orozco y Pierre Lévy. Los desarrollos de estos autores nos permiten establecer conexiones significativas entre nuestra perspectiva filosófica y nuestros referentes empíricos.

El colombiano Armando Silva Téllez, desarrolla el concepto de imaginarios urbanos para dar cuenta de los procesos construidos por los ciudadanos de a pie, destacando que lo que implica a la ciudad no es solo su dimensión física, sino, también, los sentidos y los significados que construyen los ciudadanos de manera simbólica. Entiende lo urbano, no como una mera adscripción al territorio físico, sino como un estilo de vida contemporáneo con dimensiones estéticas. En esta medida trasciende las oposiciones campo / ciudad y real / ficción (Silva, 2004).

La idea de procesos de hibridación cultural desarrollada por el argentino mexicano Néstor García Canclini, nos aporta la posibilidad de comprender la 
cultura como un proceso dinámico que pierde en la demarcación de límites territoriales definidos, pero gana en la emergencia de nuevas construcciones gracias a la co - existencia simultánea de múltiples temporalidades y cosmovisiones. Trasciende, por tanto, las oposiciones moderno / tradicional, centro / periferia, culto / popular; entre otras (García, 2004).

El tunesino - canadiense Pierre Lévy aborda los fenómenos relacionados con el ciberespacio y la cibercultura. Al primero lo define como la interconexión de todos los ordenadores del mundo; mientras que a la segunda la entiende como la acción ejercida por los intelectos - agentes en la plataforma del ciberespacio, desde las dinámicas propias de la inteligencia colectiva. Destaca que las características propias de la denominada web 2.0 pueden propiciar ejercicios ciudadanos virtuales que solo cobran sentido en relación de continuidad con el mundo físico. Esta potencialidad se basa en el hecho de que la web 2.0 restituye la unidad entre la oralidad, la lecto - escritura y la imagen y en la posibilidad de que los seres humanos puedan autodeterminarse desde la inmanencia y no desde lo trascendente, tal como sucedió hasta lo que él denomina la era de las tecnologías molares ${ }^{4}$ Trasciende las oposiciones: virtual / físico, oralidad/ lecto - escritura; imagen / lecto - escritura, actual / potencial, inmanencia / trascendencia (Lévy, 2004).

El mexicano Guillermo Orozco, destaca la importancia de las pantallas en la formación de ciudadanías. Al abordar la transición de la pantalla análoga hacia las pantallas digitales, plantea la posibilidad de que aquellos que, en algún tiempo, eran únicamente receptores, se conviertan, hoy día, en receptores y productores al mismo tiempo. En tal sentido, las pantallas no son un obstáculo para la formación de ciudadanías críticas y reflexivas; por el contrario, se constituyen en un elemento catapultador de este proceso. Trasciende las oposiciones productor / receptor, cultura de masas / pensamiento crítico (Orozco, 2001).

Entretanto, el componente sistémico, aborda la comunicación como un proceso emergente que opera a partir de las relaciones de expectativas que se conjugan entre los integrantes del proceso comunicacional; la comunicación en su condición de emergencia no es un proceso normativo que tenga que derivar en algún tipo de consenso; sino un proceso contingente que opera

4 Estado, religiones, medios masivos de comunicación. 
con independencia del sí o del no, de la aceptación o del rechazo. La teoría de los sistemas sociales del sociólogo alemán Niklas Luhmann se constituye en la base de este componente. Este referente teórico, ha permitido que el grupo de investigación comprenda los procesos de comunicación ciudadanos, no de manera unidireccional, como bien lo entendería la metáfora del impacto, sino desde la complejidad y la contingencia (Luhmann, 1998).

En síntesis, los núcleos temáticos y los referentes empíricos bajo los cuales opera el grupo de investigación en mención, siguen siendo los mismos que corresponden a la comunicación educativa como campo del conocimiento emergente. En esta medida, toma como fuente de inspiración lo ya construido, pero también, funge como un actor que aporta a la discusión del campo tanto en términos teóricos, como metodológicos y todos aquellos relacionados con los objetos de estudio pertinentes. Solo que en consecuencia con el carácter inter y transdisciplinar de la comunicación educativa, se hace conciencia de que es importante crear ingenios discursivos a partir de referentes teóricos que no hagan uso de las relaciones binarias para construir sus marcos interpretativos. Consideramos que de esta manera el campo en mención se hace más prolifero en el aporte de nuevos sentidos cuando de abordar la educación en relación de continuidad con la comunicación y la cultura se trata.

A continuación haremos referencia a los diferentes ejercicios de investigación que han servido como escenario de operacionalización de la perspectiva anteriormente descrita.

\section{Puesta en escena de la perspectiva semiótico - antropológica y sistémica}

La producción académica de la Maestría en Comunicación Educativa, se ha estructurado en tres ámbitos. El primero, hace referencia a las propuestas de tesis de los estudiantes; el segundo, abarca los procesos de indagación del GICE (Grupo de Investigación en Comunicación Educativa); y el tercero, corresponde a la Revista Miradas, escenario de reflexión y retroalimentación de la variabilidad del abordaje de los diferentes objetos de estudio de la comunicación educativa. 
Entre las dos décadas comprendidas entre 1990 y el 2014, se han elaborado más de 110 propuestas de tesis organizadas en tres períodos temporales. El primero, toma como rango cronológico desde el año 1990 hasta el $2002^{5}$; el segundo, desde el 2003 al 20076; y el tercero, del 2008 hasta el 2014. A su vez, cada período se ha estructurado con relación a las líneas de investigación del grupo en comunicación educativa, al tiempo que las ha fortalecido: $L a$ educación en los medios y los medios en la educación, la comunicación y la educación en procesos de transformación cultural y nuevas tecnologías para la educación. (Ver gráficas: propuestas de tesis estudiantes de la Maestría en Comunicación Educativa por rangos temporales, según líneas de investigación).

Gráfica 1: Propuestas de Tesis 1990 - 2002 por Líneas de Investigación

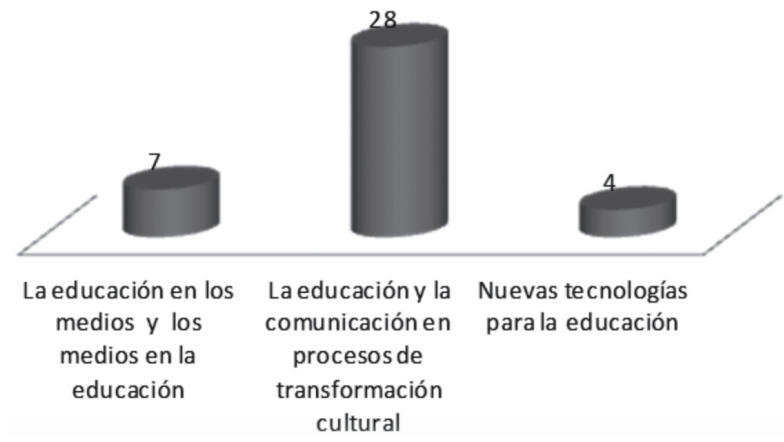

Fuente: Elaboración propia 
Gráfica 2: Propuestas de Tesis 2003 - 2007 por Líneas de Investigación

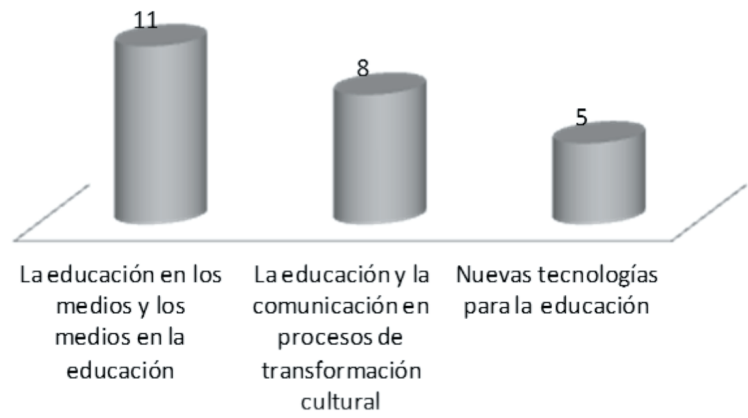

Fuente: Elaboración propia

Gráfica 3. Propuestas de Tesis 2008- 2014 por Líneas de Investigación

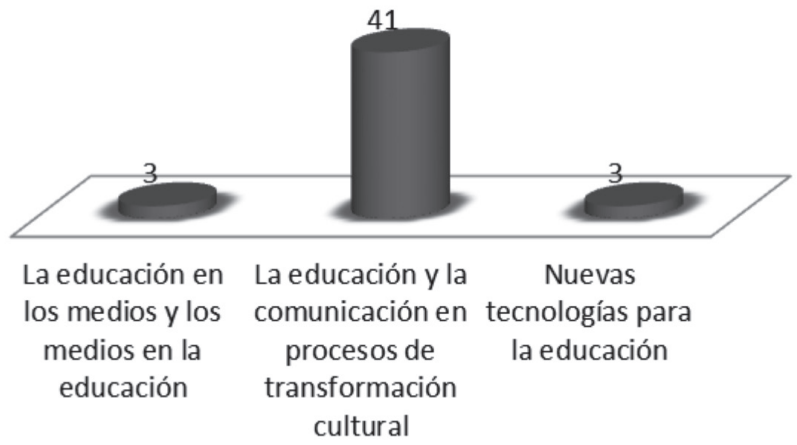

Fuente: Elaboración propia

Los pretextos semióticos abordados en la Línea de investigación: la educación en los medios y los medios en la educación, son múltiples: telenovelas, programas infantiles, programas deportivos, programas culturales, noticieros, cabezotes de seriados de televisión, videojuegos, cine, pornografía, emisoras, programas radiales, retóricas de políticos y periodistas, mensajes publicitarios; entre otros. Cada uno representa un cúmulo de materiales u "observadores de primer orden" que hacen posible construir las "observaciones de segundo orden" requeridas en la configuración de las distinciones del objeto de estudio 
de la línea: los procesos de aprendizaje potencializados por los medios de comunicación y el papel de las instituciones educativas en relación con los medios. En este horizonte, se conciben los medios no solo como simples ayudas didácticas sino como artefactos cargados de sentidos culturales, de concepciones de mundo y de significados que posibilitan recrear y crear prácticas pedagógicas diversas.

Por su lado, la línea de investigación la comunicación y la educación en procesos detransformación cultural, recurre a variados referentes semióticos: programas de prevención y promoción de la salud, el museo Quimbaya, el barrio, la ciudad, el carnaval, la sexualidad, el rock, la prostitución, la escuela nueva, las familias de migrantes, la prensa local y nacional, los hinchas de los clubes deportivos de futbol, la fotografía, las imágenes religiosas, los sitios web, la literatura, las crónicas, el cine, el ocio y la vida cotidiana, entre otros. Objetos que posibilitan reflexionar en torno a los usos y evocaciones que sobre las ciudades construyen sus habitantes; y avanzar, desde una perspectiva estética y de la percepción sensorial ciudadana, en la configuración e identificación de los modos de ser urbanos en la contemporaneidad.

La tercera línea denominada nuevas tecnologías para la educación, circunscribe sus objetos de referencia en el marco de la sociedad de la comunicación y la información. Para ello, no solo hace uso de espacios como el centro de recursos informáticos de la Universidad Tecnológica de Pereira, asignaturas virtuales, software; sino que crea escenarios virtuales de aprendizaje, material educativo computacional, propuestas metodológicas para la construcción de módulos en entornos virtuales; con el propósito de visibilizar el impacto de la tecnologías de la información y la comunicación en la escuela, en los procesos y en las comunidades de aprendizaje.

En conexión con las líneas de investigación, fortalecidas por las propuestas de tesis de los estudiantes, el GICE ha consolidado una serie de ejercicios de investigación para operacionalizar los objetos de estudio de la comunicación educativa desde la perspectiva semiótico - antropológica y sistémica, a saber: 


\section{Imaginario Femenino y ciudad. Pereira y su evocación de mujer}

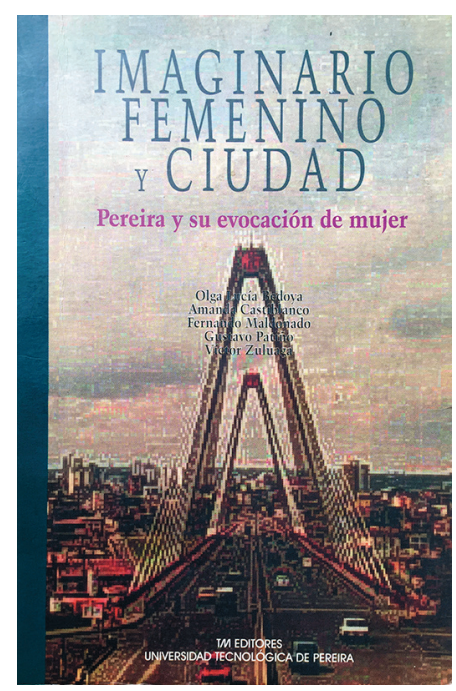

Desentrañar los temores, las expectativas, los sueños, la manera de usar y evocar la ciudad e indagar sobre la concepción que de ciudad tienen los ciudadanos de Pereira, se constituye en la primera indagación del grupo de investigación en comunicación educativa. En esta investigación, se tomaron tres ejes de análisis: "las evocaciones", "los usos" y "la participación ciudadana", siguiendo el modelo propuesto por Armando Silva para el análisis de las metrópolis latinoamericanas. A partir de lo cual, se concluye que la ciudad es vista y leída de una manera particular a partir del género y las edades de los encuestados, ya que desde esas diferencias de edades y géneros se vive, construye y usa la ciudad como un todo. Los habitantes de la ciudad identificaron los componentes físicos de esta (barrios, iglesias, parques, entre otros), al igual que sus discursos y relatos sobre Pereira y sus mujeres. No obstante, al indagar por su participación política, se registró una disyunción entre vivir la ciudad y participar políticamente en ella. Por un lado, están las evocaciones y los usos concretos que de la ciudad hacen sus habitantes y, por otro, se encuentra la posibilidad de participar políticamente en las decisiones que afectan la ciudad y sus ciudadanos.

\section{Paradoja de la ciudadanía en Pereira. Entre los ciudadanos jurídicos y los itinerantes $(2000-2003)$}

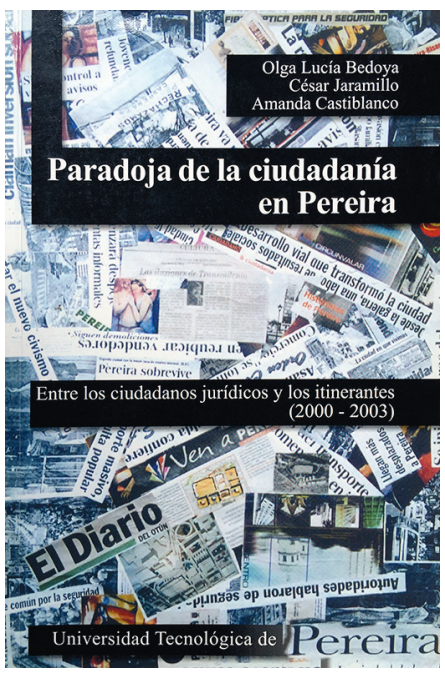

La diferenciación registrada entre vivir, hacer la ciudad y participar políticamente en sus decisiones, lleva al GICE a indagar la forma institucional y jurídico política de pensar y construir la ciudad. Para ello, se hace un seguimiento a la prensa local de la ciudad de Pereira (Diario del Otún y la Tarde 2000 - 2003), con el objetivo de complejizar la categoría de ciudadano-a. La orientación teórica y metodológica se construye a partir del enfoque sistémico inspirado en la teoría de los sistemas sociales propuesta por el sociólogo Alemán Niklas Luhmann y de los imaginarios sociales del sociólogo Español, Juan Luis Pintos. A partir de lo cual se establece, por un lado, que el tipo de ciudadano recreado y creado en la prensa local de la ciudad está inspirado en la concepción jurídica política propia de la modernidad occidental; y por el otro, se evidencia un distanciamiento entre los administradores políticos y el público de ciudadanos en la manera de construcción e imaginar la ciudad. 


\section{Memoria y ciudad: Pereira post - sísmica 2001 - 2006. Otras cartografías desde la percepción ciudadana}

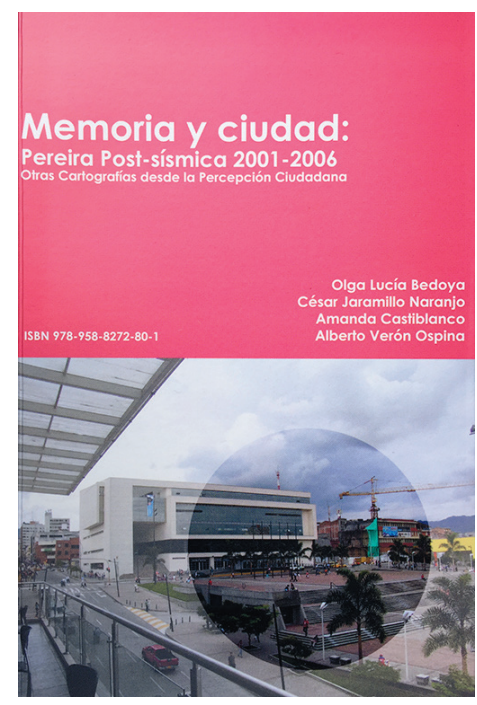

La brecha existente entre quienes planifican la ciudad y los ciudadanos concretos, inspira al GICE a conocer las percepciones de los ciudadanos de Pereira, frente a los cambios de la ciudad post-sísmica (20012006); conjugando las concepciones de los planificadores de la ciudad y las percepciones del público de ciudadanos que han vivido directa o indirectamente el proceso de renovación urbana. Esta investigación analiza dinámicamente las relaciones entre las propuestas de los planificadores de la ciudad y las respuestas del público de ciudadanos. Retoma de la corriente francesa la propuesta teórica de Henry Lefevre que da cuenta la relación "vivido" / "concebido", y la propuesta metodológica del investigador colombiano Armando Silva de los "croquis urbanos", como un medio para visualizar las percepciones de los ciudadanos frente a la ciudad.

\section{Modos de ver. Los sentidos de la comunicación educativa}
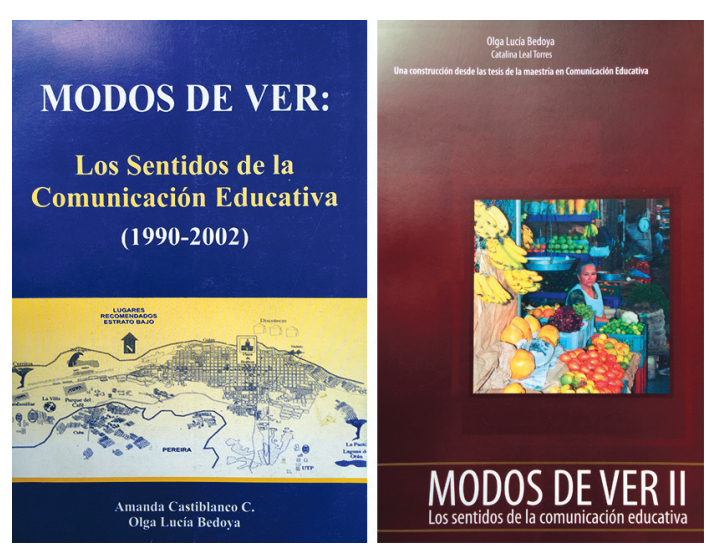

Modos de Ver I (1990 - 2002) y Modos de ver II (2003- 2008), recogen las propuestas de tesis de los estudiantes de la Maestría en Comunicación Educativa de la Universidad Tecnológica de Pereira. Se configuran en un estado del arte que pone en escena las tendencias de investigación emergentes en la región; acompañado de un ejercicio sistemático de comparación en torno a los esquemas observacionales, marcos teóricos y metodológicos que delimitan la comunicación educativa no solo como concepto sino como campo de estudio. 


\section{Antropología del Megabús}

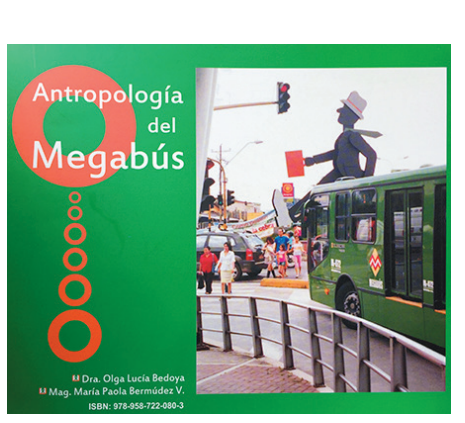

Antropología del Megabús, sintetiza las transformaciones en el espacio, la temporalidad, la movilidad y los cambios en los modos de vida de los usuarios del transporte público en la ciudad de Pereira a partir de la implementación del sistema integrado de transporte masivo. Desde la perspectiva de la teoría de la comunicación y los medios simbólicamente generalizados de Niklas Luhmann se analiza la propuesta del sistema integrado como acción de alter (administración), con relación a las manifestaciones simbólicas de ego (ciudadanos - usuarios).

\section{Pereira imaginada}

Pereira imaginada nace del proyecto internacional "Colección Ciudades Imaginadas", liderado por el investigador colombiano Armando Silva en América Latina y España. Desde una perspectiva estética y de percepción sensorial ciudadana, narra la ciudad de los ciudadanos, la ciudad/des que llevan en sus mentes y en los modos de vida. El "paradigma de la ciudad imaginada", emerge en términos de Silva (2007), cuando es posible hacer la distinción entre la ciudad de los arquitectos,

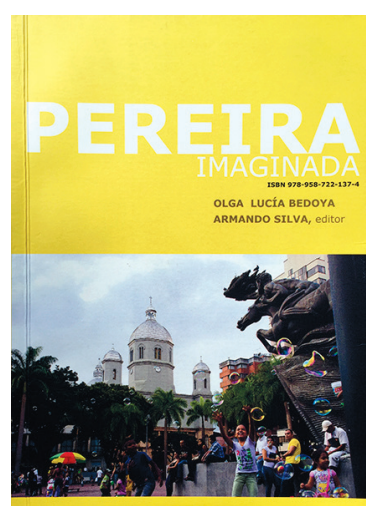
la ciudad física, la ciudad de las edificaciones y de las calles, de esta otra, la ciudad de la comunicación, de lo urbano, de "los anuncios" y de los "productos digitales o señales". Exige desplazarse del lugar geográfico, físico, tangible y visible (grafitis, vitrinas), a una ciudad no visible, a la ciudad de los ciudadanos, a la/s ciudad/des que llevan en sus mentes, a una ciudad desde la percepción ciudadana, del "deseo" ciudadano. En concomitancia con la lógica tríadica contemporánea, inspirada en la semiótica de Charles S. Peirce, la perspectiva ciudadana abordada en el libro, y en la estructura general de todos los textos de la colección, interrelaciona la tricotomía: ciudad, ciudadanos y otredades. La ciudad en analogía al "modo de ser" como "posibilidad cualitativa siempre presente" es primeridad, que a su vez se subdivide en una nueva tricotomía: cualidades, calificaciones, y escenarios. Los ciudadanos en razón a la división tricotómica del ser se constituyen en la segundidad, que a la vez comprende las temporalidades, las marcas y las rutinas. Una última tricotomía la constituye la otredad, como terceridad que da paso al desarrollo de la percepción, desde la comparación con las ciudades cercanas, las ciudades lejanas y las ciudades anheladas. 


\section{Revista Miradas}

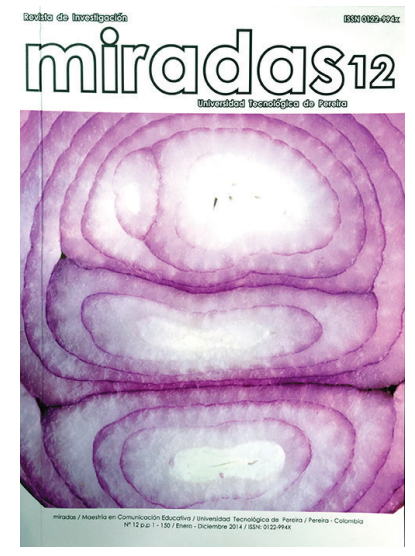

Finalmente, la Maestría en Comunicación Educativa, sistematiza la producción investigativa en la Revista Miradas. Escenario de reflexión promovido por los estudiantes, los egresados, los profesores y la comunidad académica nacional e internacional que intenta comprender el carácter relacional entre las teorías de la Comunicación y la Educación. En la actualidad, dicha revista se encuentra indexada en categoría C en COLCIENCIAS.

\section{A modo de cierre}

Para concluir, haremos referencia a tres aspectos: i) la relación comunicación - educación; ii) la concepción de las tecnologías de la información y la comunicación como dispositivos culturales; iii) las implicaciones de la perspectiva semiótico - antropológica y sistémica.

El primer desplazamiento de la comunicación educativa tiene que ver con la transición de un enfoque disciplinar que distinguía de manera desarticulada las perspectivas teóricas y metodológicas de ámbitos del conocimiento como la comunicación y la educación. Desde una postura inter y transdisciplinar se articulan, no solo las orientaciones teóricas y metodológicas, sino también los problemas relacionados con las disciplinas referidas en tanto fuente de inspiración para la construcción de nuevos sentidos.

Los sentidos emergentes a este proceso de transversalización de teorías, métodos y problemas de investigación, suscitaron la necesidad de articular a la discusión otras disciplinas afines como la sociología, la antropología, la semiótica, entre otras. En el campo de la educación, esto implicó establecer conexiones entre escuela, cultura y sociedad; así como entre los niveles formal, no formal e informal de los sistemas educativos. 
De lo anterior se deriva el segundo desplazamiento consistente en la concepción de las tecnologías de la información y de la comunicación como un fenómeno cultural que media los procesos educativos; y no así, como algo totalmente ajeno y adverso a estos. Esto pasa por tomar distancia de la concepción de las tecnologías educativas que suscriben a las TIC como un soporte material de las ya tradicionales concepciones, estrategias y escenarios del proceso educativo.

Tal concepción de las TIC como mediación, sugiere pensar que dispositivos comunicacionales como la oralidad, la lecto - escritura y la imagen traen consigo concepciones de mundo que suponen unos modos de ser y de estar en este. Además, propicia sensibilidad para comprender que, en el escenario de la web 2.0, se restituye la unidad entre estos tres dispositivos; lo cual demanda abordajes complejos y relacionales del escenario cultural contemporáneo.

En cuanto a lo educativo, esto sugiere la necesidad de una escuela más abierta a la cultura que tenga la capacidad de diseñar currículos flexibles y que adapte sus modalidades y estrategias educativas a la pregunta por el aprendizaje del otro. Problemáticas de este tipo solo son abordables desde una perspectiva inter y transdisciplinar, tal como se planteó en el primer desplazamiento.

En conexión con lo anteriormente dicho, se plantean las implicaciones del tercer desplazamiento relacionado con el enfoque semiótico - antropológico y sistémico desarrollado al interior del grupo de investigación en comunicación educativa - GICE -. Si bien la comunicación educativa reconoció desde sus orígenes la necesidad de trascender las fronteras demarcadas por los enfoques disciplinares, no hizo lo propio en cuanto al carácter binario que ha estado presente en todos los sistemas de conocimiento de la denominada sociedad occidental. Por ello las oposiciones centro / periferia, imperio / colonia, primer mundo / tercer mundo; entre otras, siguen siendo lugares comunes en las reflexiones construidas en este ámbito.

No es que estemos negando la existencia de tales oposiciones, pero pensamos que apalancar una lectura que las aborde desde una perspectiva de la continuidad posibilita la construcción de ingenios discursivos que aportan nuevos sentidos sobre el fenómeno social y cultural contemporáneo; con lo cual se pueden construir nuevos paradigmas basados en el reconocimiento de la coexistencia simultánea de diferencias sociales, culturales y temporales, 
y no en la negación de las unas por las otras. Por tanto se pierde en límites definidos, pero se gana en comunicación; tal vez por eso sugerimos que una perspectiva basada en la ciudadanía universal, sería el aporte de América Latina para el mundo desde los lentes de la relación comunicación - educación.

Este libro se estructura a partir de tres capítulos correspondientes con cada una de las líneas de investigación de la Maestría en Comunicación Educativa. Por tanto, en el primer capítulo, el lector se encontrará con una relación de los trabajos de grado asociados a la línea de investigación: "La educación en los medios y los medios en la educación"; en el segundo capítulo, se hará referencia a los trabajos relacionados con la línea de investigación: "La comunicación y la educación en los procesos de transformación cultural". Entretanto, el tercer capítulo da cuenta de la línea de investigación: "Nuevas tecnologías para la educación”. El cierre de este libro se hace con una aproximación, a manera de síntesis, que nos permite tener una visión global sobre los aportes que se están haciendo desde la Maestría en Comunicación Educativa, al campo del conocimiento que nos compete.

Finalmente, es importante aclarar que los apartados referidos por cada uno de los trabajos de grado incluidos en estelibro, fueron extraídos delos documentos originales de los autores, por este motivo, se les da el reconocimiento exigido al aparecer como autores de cada uno de los trabajos en mención. Si el lector desea acceder a la información completa de cada uno de los trabajos, puede acudir al catálogo virtual de la biblioteca de la Universidad Tecnológica de Pereira a través de la página: www.utp.edu.co 

Capítulo 1 



\section{Línea de investigación: La educación en los medios y los medios en la educación}

\section{La educación en los medios y los medios en la educación}

Esta línea de investigación tiene como propósito abordar la relación que se establece entre los medios de comunicación y su uso en procesos educativos bien sea de tipo formal o no formal. Los interrogantes que suscitan la realización de trabajos de investigación bajo esta línea tienen que ver con los procesos de recepción de contenidos mediáticos realizados por los usuarios en contextos educativos, la construcción de sujetos autónomos y críticos en los procesos de recepción y producción de contenidos mediáticos y la relación que se puede establecer entre construcción de ciudadanía activa y consumo y producción de contenidos mediáticos.

Los trabajos que integran esta línea de investigación, dan cuenta de los desplazamientos teóricos que han evidenciado conceptos como recepción, comunicación y ciudadanía. El rasgo común a los desplazamientos de estos tres conceptos, tiene que ver con el papel activo que tienen los sujetos 
involucrados en los procesos asociados a los mencionados objetos. Se destaca que la construcción de mundos posibles se constituye en el eje central para la construcción de conocimiento sobre los objetos seleccionados.

\section{Análisis de la competencia televisiva en la interacción maestro - estudiante de básica secundaria y su impacto en la audiencia adolescente televisiva}

Autor: Edwin Andrés García Loaiza

Año: 2009

\section{Resumen:}

Al pretender establecer la relación entre competencia televisiva en recepción activa y la mediación en recepción de contenidos televisivos por parte de 20 docentes y 50 estudiantes de las instituciones educativas: Hernando Vélez, Villa Fanny, Pablo Emilio Cardona, Cartagena y San Nicolás de los municipios de Pereira y Dosquebradas; este proyecto de investigación hace uso de las teorías de la recepción activa.

\section{Palabras clave:}

Recepción activa, competencia televisiva, televidencias, audiencias, mediaciones.

\section{Descripción:}

En el marco del análisis de los procesos de recepción, esta investigación se plantea la siguiente pregunta ¿Cómo es la relación entre la competencia televisiva en recepción activa de contenidos televisivos por parte de 20 docentes y la mediación en recepción de contenidos en 50 estudiantes de 
secundaria de las escuelas públicas: Hernando Vélez, Villa Fanny, Pablo Emilio Cardona, Cartagena y San Nicolás de los municipios de Pereira y Dosquebradas? La conceptualización sobre la recepción activa se constituye en el marco teórico de este proyecto. Los objetivos son, general: Establecer la relación entre la competencia televisiva en recepción activa por parte de 20 docentes con la mediación en contenidos televisivos en 50 estudiantes de las escuelas públicas: Hernando Vélez, Villa Fanny, Pablo Emilio Cardona, Cartagena y San Nicolás de los municipios de Pereira y Dosquebradas para conocer su preponderancia en el uso de los contenidos mediáticos en la educación formal. Los objetivos específicos son: a) Conocer las percepciones de los docentes frente al uso de un medio de comunicación masivo como la televisión en relación a su valor educativo; b) Analizar la relación entre competencia televisiva de docentes con los principios de recepción activa de contenidos mediáticos con estudiantes; c) Conocer los hábitos de consumo televisivo de los grupos de estudiantes participantes en la investigación. Este trabajo resulta de interés puesto que responde a una necesidad sobre fundamentación de los procesos que se desarrollan al interior del aula en relación con la televisión.

\section{Metodología:}

Al ubicarse en el paradigma cualitativo, la metodología empleada en esta investigación es de tipo no experimental, puesto que hay ausencia de manipulación de variables; además, lo que se pretende es dar explicación a las posibles relaciones existentes entre la percepción de los docentes sobre las mediaciones de contenidos televisivos y su valor educativo, a partir de la competencia televisiva, lo cual implica el uso de un estudio de tipo descriptivo correlacional.

\section{Conclusiones:}

- En cuanto a las correlaciones encontradas, se concluye en referencia a la competencia televisiva y la recepción activa por parte de los docentes, que no hay para la muestra seleccionada un porcentaje representativo en cuanto al conocimiento de la televisión en relación con características de su lenguaje, aspectos tecnológicos y elementos discursivos, con la presencia 
de otras variables a nivel de correlación; lo que quiere decir que a pesar de que algunos docentes reconocen en la estructura televisiva un lenguaje conformado por palabras, signo e imágenes en movimiento, no usan dicho conocimiento para establecer acercamientos o análisis de contenido como el comercial enseñado, análisis de escenas, características de ambientación, personajes y descripciones en general.

- En lo que respecta a las correlaciones encontradas que pueden relacionarse con los componentes primarios de la competencia televisiva se evidenciaron correlaciones que son significativas, pero no representativas para la población de docentes encuestados, por lo que cabe decir que la perspectiva de estos frente a la televisión como causante de diferentes problemáticas en la población, se presenta pero en un menor nivel; y por el contrario, existen percepciones positivas en cuanto al uso educativo de la televisión y frente a la formación de receptores críticos en relación con el consumo de contenidos televisivos.

\section{La palabra de la radio al aula: formación de maestros que atienden estudiantes con discapacidad visual en las aulas integradoras. El caso de la Institución Educativa Pablo Emilio Cardona}

Autor: Carlos Andrés Sánchez Muñoz

Año: 2009

\section{Resumen:}

Este trabajo tiene como propósito identificar los problemas de formación que se presentan en los maestros que atienden estudiantes con discapacidad visual y baja visión no funcional en las aulas integradoras de la Institución Educativa Pablo Emilio Cardona de la ciudad de Pereira. Los resultados de esta indagación, se constituyen en la base para el diseño de una propuesta de 
mejoramiento desde la comunicación educativa; por lo que se hace uso de los principios de la pedagogía de la comunicación desarrollados por Mario Kaplún.

\section{Palabras clave:}

Comunicación - educativa, radio, docentes, estudiantes, discapacidad visual.

\section{Descripción:}

La condición generalizada de considerar el sentido de la vista como el primero en una escala jerárquica sensorial, que se ve apoyada en la posibilidad que tiene este sentido para percibir las características de los hechos, objetos, sujetos, imágenes, entre otros; es una de las causas por las que quizás, en nuestro modelo educativo, los maestros complementan su discurso con el lenguaje no verbal, a lo cual se le suman ayudas audiovisuales que, bien utilizadas, dinamizan y enriquecen la presentación de los contenidos educativos. Sin embargo, este tipo de lenguajes se convierten en protagonistas, relegando al lenguaje verbal a un lugar secundario; esta situación, excluye a todas las personas que no cuentan con el sentido de la vista; por lo que este trabajo se propone la siguiente pregunta de investigación: ¿Qué tipo de problemas se presentan en la formación de los maestros que atienden estudiantes con discapacidad visual y baja visión no funcional en las aulas integradoras de la Institución Educativa Pablo Emilio Cardona de la ciudad de Pereira? Los principios de la pedagogía de la comunicación desarrollados por Mario Kaplún, se constituyen en el referente teórico de este proyecto. Los objetivos son, general: Determinar qué características debe reunir una propuesta de formación para ofrecer soluciones a los problemas de codificación / emisión identificados en los maestros que atienden estudiantes con discapacidad visual y baja visión no funcional en las aulas integradoras de la Institución Educativa Pablo Emilio Cardona de la ciudad de Pereira. Los objetivos específicos son: a) Determinar qué tipo de comunicación educativa y qué tipo de contenidos enmarcan las experiencias radio educativas que sirven como antecedentes a la presente investigación; b) Identificar qué tipo de problemas dificultan a los maestros su proceso de enseñanza a los estudiantes con discapacidad visual total y baja visión no funcional atendidos en la Institución Educativa Pablo 
Emilio Cardona; c) Diseñar una propuesta de formación que dé respuesta a los problemas identificados en la codificación / emisión de los mensajes de los maestros en el proceso de enseñanza a los estudiantes con discapacidad visual total y baja visión no funcional atendidos en la Institución Educativa Pablo Emilio Cardona. Este trabajo tiene como propósito aportar a la educación inclusiva, desde la comunicación educativa.

\section{Metodología:}

Esta investigación se enmarca en los parámetros propuestos por el paradigma cualitativo. Como estudio de caso, tiene la pretensión de reconocer las características latentes del fenómeno investigado para proceder a establecer relaciones.

\section{Conclusiones:}

1. Se logró determinar que las experiencias radio - educativas examinadas, corresponden al tipo de comunicación educativa denominada: "comunicación por los medios".

2. Se lograron identificar diez problemas que dificultan a los maestros la enseñanza de sus respectivas asignaturas a los estudiantes con discapacidad visual y baja visión no funcional que son atendidos en la Institución Educativa Pablo Emilio Cardona de la ciudad de Pereira. Estos problemas fueron organizados en igual cantidad de categorías que emergieron de los propios datos obtenidos y que al ser analizados posibilitaron el surgimiento de las subcategorías. Dichos problemas tienen origen en los procesos de formación para la educación general que recibieron los maestros.

3. Se logró identificar que los problemas de formación identificados en los maestros, que podrían ser solucionados a través de una propuesta comunico - educativa, son aquellos que corresponden a la codificación / emisión de los mensajes. 


\section{Síntesis}

En el marco de la línea de investigación: "la educación en los medios y los medios en la educación", la categoría mediación se constituye en un factor central para comprender la relación medios - educación. La trayectoria investigativa en este campo deja entrever dos acepciones de la mencionada categoría: por un lado están las mediaciones que ejercen los medios y, por otro, se evidencian las mediaciones planteadas por los usuarios en su proceso de interacción con las pantallas.

Las perspectivas teóricas suscritas desde la comunicación educativa, indican que ambos tipos de mediaciones suceden de manera complementaria y continua en todos los procesos de interacción que se generan entre los usuarios y las pantallas. De esta manera lo emergente a dicho proceso lleva a repensar los supuestos filosóficos sobre los que se han abordado las concepciones de realidad, verdad, cultura, cotidianeidad, objetividad, entre otros. Dichas concepciones no se pueden asociar a las dualistas ideas de objetividad, imparcialidad y verdad absoluta, presentes en los sistemas filosóficos de la cultura occidental.

Asistimos, entonces, a un proceso de mediación de mediaciones que imbrica las expectativas de los medios con las de los usuarios. Dicha conexidad suscita la emergencia de mundos posibles en los que la reapropiación simbólica y la continuidad entre consumo y producción se constituyen en los ejes articuladores de los nuevos sentidos y significaciones.

El carácter emergente de los mundos posibles construidos a partir de la interacción entre usuarios y pantallas, permite entrever ciertos desplazamientos que han evidenciado conceptos como recepción, audiencias, aprendizaje, mediaciones; entre otros. Lo cual lleva al planteamiento de los siguientes interrogantes: $i \mathrm{La}$ indistinguibilidad entre aprendizaje $\mathrm{y}$ entretenimiento implica relativizar el protagonismo de la escuela y el libro (lectoescritura), como únicos dispositivos válidos para la producción y difusión del conocimiento? Si hablamos de un receptor que es pasivo a uno que es productor y consumidor al mismo tiempo ¿No es posible hablar, también, del desplazamiento de un sujeto que solo se dedica a aprender a uno que es co-productor de conocimientos? ¿Podemos hablar de nuevas posibilidades para el proceso del pensar a partir de la restitución de la unidad entre consumo y producción? 

Capítulo 2 



\section{Línea de investigación: La comunicación y la educación en los procesos de transformación cultural}

\section{La comunicación y la educación en los procesos de transformación cultural}

La línea "La comunicación y la educación en procesos de transformación cultural", en primer lugar, restituye dos áreas disciplinares, que si bien, tienen cada una sus objetos de estudio particulares, se caracterizaron en las Facultades de Educación y Comunicación de las universidades, no solo del país, sino de América Latina, por configurarse de forma aislada y mutuamente excluyente.

En la actualidad la Comunicación y la Educación se implican una a la otra desde la comunicación educativa para comprender fenómenos contemporáneos que son objeto de estudio por parte de las Ciencias Sociales y Humanas en general. No obstante, tejen puentes con la Antropología, la Sociología, la Historia, la Filosofía y la Semiótica, irrumpiendo con la concepción disciplinar del conocimiento

En este contexto, el objeto de la línea se circunscribe en la distinción de los procesos de recepción, el consumo cultural y los modos de ser urbano. En 
coherencia con los lenguajes que exigen los abordajes de estos fenómenos, las orientaciones teóricas pueden ser múltiples, entre ellas las diversas tesis adscritas a esta línea se conceptualizan desde autores como: Néstor García Canclini, Rosana Reguillo, Pierre Lévy, Guillermo Orozco Gómez, Germán Muñoz, Omar Rincón, Umberto Eco, Charles Sanders Peirce y Armando Silva Téllez.

Los dos últimos autores le han permitido a la Maestría en Comunicación construir una orientación teórica y metodológica que dialoga con otras perspectivas, por lo que entre el 2008 y el 2014 se han presenciado al interior de las investigaciones tres desplazamientos:

- Modos de ser urbanos centrados en la interacción ciudadano - ciudad.

- Modos de ser urbanos centrados en las micro etnografías o en los micro procesos imaginarios.

- Modos de ser urbanos centrados en la configuración de los archivos ciudadanos.

El primer desplazamiento se adscribe a la metodología de imaginarios urbanos del investigador colombiano Armando Silva Téllez, que tiene como objetivo reconocer los "croquis afectivos" o la diversidad de formas de ciudad según los "puntos de vista" o filtros de percepción de los ciudadanos. En este desplazamiento se examinan las formas de inter-acciones humanas, sociales, de interacción con el espacio hasta la captación del sentir colectivo (Silva, 2007, p. 36).

Con el propósito de conocer modos de ser urbanos la propuesta metodológica del investigador Silva Téllez, se estructura a partir de la lógica trial peirceana en tres tricotomías: ciudad, ciudadanos y otredades.

Este desplazamiento se materializa en la Maestría en Comunicación Educativa a través del macroproyecto Pereira Imaginada 2009- 2014 (fase 1), que tiene como finalidad conocer los imaginarios que recrean y construyen los habitantes de la ciudad de Pereira.

A diferencia del primer desplazamiento, los modos de ser urbanos centrados en las micro etnografías o en los micro procesos imaginarios (Pereira Imaginada fase 2), emergen con el propósito de profundizar en los hallazgos obtenidos en la investigación Pereira Imaginada. Para ello se selecciona un imaginario 
de la ciudad de Pereira, se examina en sus variantes de funcionamiento y se procede a través de ejercicios etnográficos a comprender la configuración del imaginario.

Finalmente, el tercer desplazamiento de las investigaciones que se adscriben a esta línea (Medellín imaginada en los archivos ciudadanos), tienen como finalidad distinguir la construcción de imaginarios, pero no centrados en la relación ciudadanos y ciudad, sino en la relación ciudad y archivos ciudadanos. Para ello, se parte de la tesis que cada archivo en sus diversas modalidades público, privado o comunitario alberga sentimientos colectivos una vez son productos de la fantasía, la creatividad, un intento de plasmar la realidad de seres humanos que se inscriben en condiciones socio - espacio - temporales. Este desplazamiento, aporta infinidad de pretextos semióticos para el reconocimiento de imaginarios como el cine, la literatura, la televisión, la radio, la prensa escrita, el internet, entre otros.

\section{Consideraciones sobre los procesos de recepción en estudiantes de grado décimo del Instituto Agropecuario Veracruz de Santa Rosa de Cabal, Risaralda}

Autora: Doralba Gil Correa

Año: 2014

\section{Resumen:}

Enmarcado en los estudios de recepción, este proyecto de investigación tiene como propósito dar cuenta de la configuración de este fenómeno en el contexto de la sociedad contemporánea en la que la relación con la pantalla deja de ser un mero ejercicio pasivo, para convertirse en una práctica en la que la posibilidad de agencia se realiza desde dos dimensiones: por un lado, desde la posibilidad de elegir y reinterpretar simbólicamente lo que se ve; y por otro lado, desde la capacidad que adquieren los receptores de hacerse co - partícipes en los procesos de producción de contenidos gracias a las características de la web 2.0. Teniendo claro que este proceso se da en el orden 
de la potencialidad, se realiza un proceso de investigación con jóvenes de grado décimo del Instituto Agropecuario Veracruz de Santa Rosa de Cabal, Risaralda.

\section{Palabras clave:}

recepción, audiencias participativas, pantallas, mediaciones.

\section{Descripción:}

En esta investigación se aborda el proceso de recepción en la sociedad contemporánea. Se da cuenta de los diferentes tipos de audiencias, y se relacionan con los espacios interactivos de socialización utilizados por los jóvenes de hoy. Algunos de estos planteamientos son abordados desde el punto de vista de los teóricos: Guillermo Orozco, con los planteamientos de las audiencias y Pierre Lévy, con su enfoque antropológico de la cibercultura y el ciberespacio.

La pertinencia de este trabajo radica en uno de los tantos desafíos de la educación: la forma como los estudiantes recepcionan la información y a partir de ella, se comunican y socializan. Este fenómeno se convierte en preocupación para los docentes, esta encrucijada educativa actual, hace urgente que los docentes comprendamos las nuevas formas en que la información llega a estos llamados nativos digitales, de modo que podamos ser parte activa en las reflexiones pedagógicas de nuestro quehacer cotidiano, de esta forma se estarán dejando planteados algunos aportes que sirvan como punto de partida en algunas discusiones académicas.

\section{Metodología:}

Se presenta en este estudio un enfoque cualitativo que permite comprender el fenómeno en cuestión; en este caso, el proceso de recepción en el ciberespacio de los estudiantes de grado décimo del Instituto Agropecuario Veracruz de Santa Rosa de Cabal. El enfoque que aquí se utiliza es de tipo hermenéutico, el cual permite comprender los datos y, finalmente, relacionar dichos hallazgos con la teoría, de tal manera que sirvan como reflexión para la educación actual 


\section{Conclusiones:}

- Se hace evidente que los escenarios interactivos más utilizados para la recepción en los estudiantes son: la televisión y el Facebook, estos dos están presentes de una manera significativa y les ocupa gran parte de su tiempo, de allí lo importante que resulta orientar de una manera adecuada las prácticas educativas que propendan por brindarles nuevas herramientas en pro de su aprendizaje.

- Con esta investigación se puede deducir que los estudiantes del Instituto Agropecuario Veracruz de Santa Rosa de Cabal pertenecen al tipo de audiencia receptora que poco se preocupa por construir nuevos conocimientos, ni colectivizar la inteligencia, sino que, más bien, se dedican a hacer vida social, sin importarles el nuevo conocimiento ni los procesos que se desprenden de estas prácticas.

- Ni la interactividad, ni las posibilidades tecnológicas que se les brindan a las actuales audiencias, son suficientes para el desarrollo de una sociedad del conocimiento; solo el cambio en los currículos para brindarles una educación integral que les permita sacar el mayor provecho a las nuevas tecnologías, será un elemento relevante que les permita convertirse en nuevas audiencias productoras en este siglo XXI.

\section{Emprendedor $=$ comunicador de ideas: imaginarios visibilizados en los emprendedores de Parquesoft Pereira}

Autora: Ángela Perdomo Rodas

Año: 2014

\section{Resumen}

Las tesis que lleva por título "Emprendedor = comunicador de ideas: imaginarios visibilizados en los emprendedores de Parquesoft Pereira", partió de la siguiente pregunta: ¿Es posible identificar imaginarios de 
emprendimiento en los ciudadanos que hacen parte de Parquesoft Pereira? Para ello fue fundamental orientar el procedimiento a la expresión profunda de la experiencia e historia de vida de cada uno de los emprendedores seleccionados, y desde allí proyectar un documento que acercara al ciudadano a las realidades sociales e individuales que enfrentan diariamente los emprendedores de la ciudad. La metodología fue cualitativa, aunque se aplicó una técnica inicial cuantitativa como fue la encuesta. Como resultado se obtuvo que las características de un emprendedor, según los imaginarios, son: soñador-apasionado, motivado-tener confianza, creativo, tener conocimientos, habilidad para trabajar en equipo, tener y desarrollar ideas, incorporar el riesgo.

\section{Palabras clave:}

Emprendedor, imaginario, comunicador de ideas.

\section{Descripción:}

La investigadora partió de la siguiente inquietud para abordar su proceso investigativo: ¿Es posible identificar imaginarios de emprendimiento en los ciudadanos que hacen parte de Parquesoft Pereira? Dicha inquietud parte de observar los fracasos de muchas iniciativas de emprendimiento propuestas en la región. El proyecto tuvo como principal objetivo visualizar los imaginarios de emprendimiento en las experiencias empresariales de Parquesoft Pereira, en empresas como: DUTO, Ikono Telecomunicaciones, Cero K, Arvirt, Tecmovin, Idra, Quinoa, Letmi APP, Activos Multimedia y el mismo Parquesoft; para desde allí vislumbrar rasgos que tenían los emprendedores de la ciudad, enmarcados estos desde el sentir del individuo y el quehacer cotidiano.

La autora se apoyó teóricamente en Gonzalo Wandosell Fernández de Bobadilla (2003) quién presentó su tesis doctoral, titulada, La creación de empresas y el perfil del emprendedor. Análisis empírico en la comunidad autónoma de la región de Murcia; igualmente, la discusión de Armando Silva, sobre los imaginarios, (2011) y la teoría de la Innovación de Schumpeter (1943) traducido por Rubio (2010), quien plantea que lo que parece simple se puede 
convertir en algo innovador, solo es mirar con lente diferenciador para que sea útil en la sociedad de consumo; y por último, el libro La mente creativa mitos y mecanismo de A. Boden (1991), quien ratifica que el conocimiento proporciona creatividad.

\section{Metodología:}

En cuanto a la metodología, la investigadora eligió la cualitativa pero apoyándose, inicialmente, en una herramienta cuantitativa como la encuesta, para luego girar hacia técnicas más cualitativas con el propósito de profundizar en los resultados iniciales. Para el análisis y organización holística de la información, se tomó como referencia, la propuesta relacional trial del grupo de investigación en comunicación educativa de la Universidad Tecnológica de Pereira:

1. Encuesta transcrita

2. Agrupación de triadas generales por respuestas

3. Agrupación de categorías de acuerdo a la interrelación de las triadas

\section{Conclusiones:}

- De todo este proceso investigativo, la autora presenta, en un gráfico resumido, los resultados centrales a manera de conclusiones:

Las características de los imaginarios de los emprendedores giran en torno a los siguientes aspectos: 


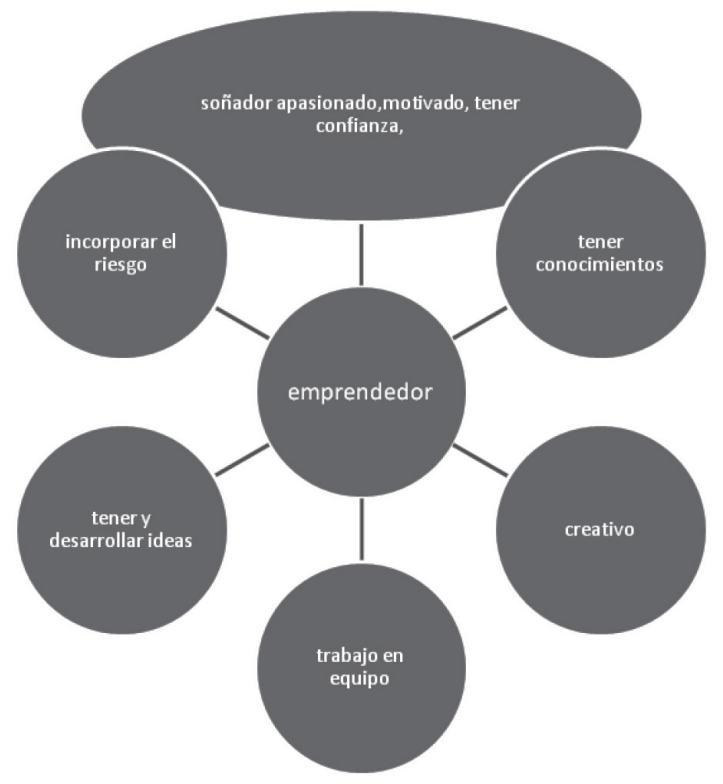

Fuente: Perdomo Rodas, Ángela (2014)

A partir de lo anteriormente descrito, la investigadora propone $e^{7}$ desarrollar un diplomado en emprendimiento en el cual se desarrolle una dinámica que permita orientar a los asistentes en las vertientes necesarias que se deben indagar y profundizar en el desarrollo de una cultura emprendedora, la cual debe ser orientada y motivada desde la academia o los diferentes grupos organizados que tiene la sociedad.

El diplomado debe tener módulos que profundicen en temas como: el conocimiento, el trabajo en equipo, el desarrollo de las ideas, el riesgo, la creatividad, las motivaciones particulares del ser (confianza, pasión, ser soñador), la comunicación, los procesos de gestión, la formación de formadores en emprendimientos.

La propuesta completa, se puede encontrar en la tesis de la autora, ubicada en la Universidad Tecnológica de Pereira. 


\section{Pereira, transición de gran ciudad a desarrollo y progreso}

Autor: César Augusto Castaño Galvis

Año: 2014

\section{Resumen}

La presente tesis desarrolló una mirada histórica de las ciudades como producto de prácticas sociales históricamente situadas. Igualmente, el discurso hegemónico del desarrollo y su incidencia en las políticas de desarrollo de los países menos avanzados. El escenario de observación, fue la ciudad de Pereira, donde se estudió la ciudad no desde lo físico sino desde la relación de los ciudadanos con ella. La metodología propuesta, fue la del investigador colombiano, Armando Silva, a partir de la categoría de imaginarios, como prácticas ciudadanas. La conclusión central de la tesis, es que Pereira se ha construido con una imagen de metrópoli, pero la vida cotidiana y la forma de pensar y actuar de los ciudadanos es de un lugar pequeño.

\section{Palabras claves:}

ciudadano, imaginario, ciudad, desarrollo, prácticas ciudadanas

\section{Descripción:}

La pregunta de investigación planteada por el autor fue “¿Es posible distinguir a través de los acontecimientos históricos narrados en la separata del Diario del Otún, imaginarios de desarrollo y progreso en la ciudad de Pereira?” El objetivo central consistió en dar cuenta de la idea de progreso y desarrollo que subyace a quienes han planeado y construido la ciudad de Pereira. La metodología trial, fue la utilizada para dar cuenta de la pregunta, la cual partió de la triada base: 


\section{Metodología:}

Figura 1. Modelo del Ser

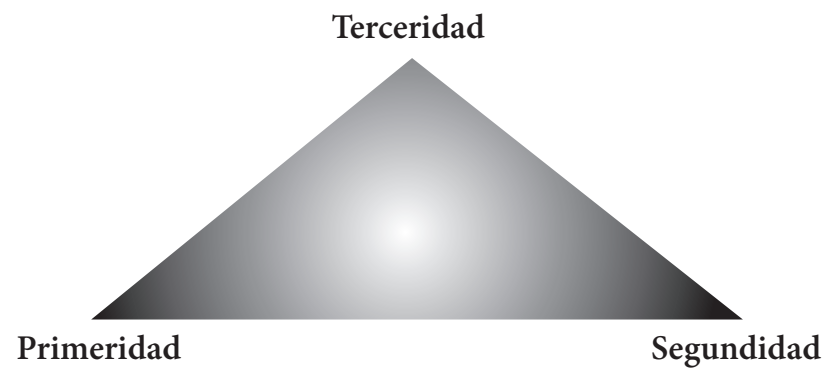

Fuente: elaboración a partir de Restrepo 1993

Aplicada al caso concreto de análisis:

Figura 2. Terceridad como combinación

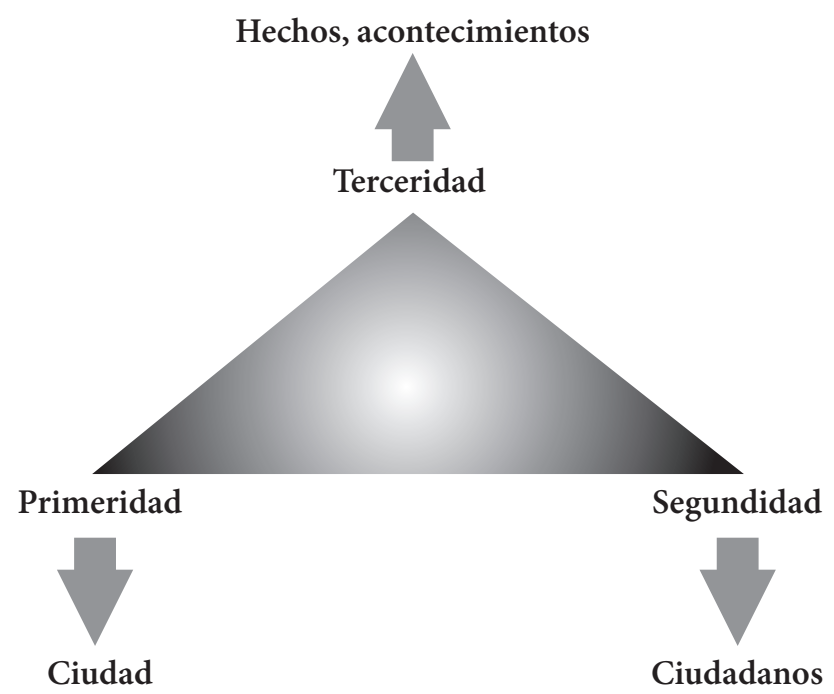

Fuente: elaboración a partir de Restrepo (1993) 
En cada vértice se ubica la información recolectada, y al final de todo el proceso, se agrupan las diferentes triadas en Nodos (tópicos parecidos), hasta saturar el dato, y tener como resultado, solo una triada, denominada de Sentido. De esta manera, lo aparentemente obvio, se diluye, emergiendo las ideas base en que se sustentan los discursos.

La información de base, fue la separata de los 25 años del Diario del Otún, que recogió los acontecimientos más importantes de la vida de la ciudad de Pereira, a partir de allí, se construyó el objeto de estudio.

\section{Conclusiones}

- El estudio arroja que el concepto de desarrollo tiene mayor prioridad que el de progreso; de otro lado, el imaginario que subyace en la separata de los 25 años del Diario del Otún de progreso y desarrollo gira en torno a lo económico, físico y lo social. En síntesis, el imaginario de desarrollo y progreso sigue siendo mayor que la realidad: se cree ser metrópoli, pero se piensa y actúa con mentalidad de un lugar pequeño.

\section{El paisaje cultural cafetero: una encrucijada entre la sostenibilidad y un futuro amenazado}

Autora: Claudia Marcela Muñoz Guzmán

Año: 2014

\section{Resumen}

La autora de la tesis El paisaje cultural cafetero: una encrucijada entre la sostenibilidad y un futuro amenazado, partió de la siguiente pregunta: ¿Qué ideas de rural/urbano, local/Cosmopolita, tradicional/moderno subyace en el proyecto y la declaratoria de paisaje cultural cafetero como patrimonio de la humanidad y qué acciones se han derivado de las entidades involucradas para garantizar la sostenibilidad, o no, de dicha declaratoria? Esta inquietud surge 
del cuestionamiento acerca de si era suficiente la declaratoria de la UNESCO para conservar el paisaje cultural cafetero o no. El autor principal, fue Néstor García Canclini, con su apuesta por el concepto de Hibridación Cultural. La metodología fue cualitativa. Se pudo evidenciar que no hay pureza en la cultura cafetera ni en lo plasmado en la declaratoria de la UNESCO, por las mezclas de las diferentes culturas, dando como resultado una cultura amalgamada, con matices diferentes tanto en sus bienes materiales como en los inmateriales, este paisaje cultural surge por el proceso de hibridación que se da entre lo tradicional/moderno, local/cosmopolita.

\section{Palabras claves:}

Paisaje cafetero, hibridación cultural, y mixturas

\section{Descripción}

El objetivo central fue analizar las ideas de rural/urbano, local/cosmopolita, tradicional/moderno que subyacen en el del proyecto y la declaratoria de paisaje cultural cafetero como patrimonio de la humanidad, (UNESCO) y qué acciones se han derivado en el gremio cafetero, en la Universidad del Quindío y Gobernación del Quindío para garantizar la sostenibilidad, o no, de dicha declaratoria. Los autores de base fueron Néstor García Canclini, especialmente con el concepto de "hibridez", que lo aplica a la cultura, la economía, la política, abordadas desde un enfoque transdiciplinario; y las teorías del sociólogo francés Pierre Bourdieu (creador del modelo sociológico conocido como "constructivismo estructuralista"), en el cual se basa Canclini.

\section{Metodología}

Se utilizó la metodología cualitativa, con el propósito de explorar las relaciones sociales y describir la realidad tal como la experimentan sus correspondientes protagonistas. Para la recolección del dato se utilizaron entrevistas y archivos oficiales del paisaje cultural cafetero, resultados que fueron examinados con el análisis de contenido y con la teoría de la lógica trial- relacional. 


\section{Conclusiones}

- Después de terminada la investigación, la autora concluye que no hay pureza en la cultura cafetera ni en lo plasmado en la declaratoria de la UNESCO, por las mezclas de las diferentes culturas, dando como resultado una cultura amalgamada, con matices diferentes tanto en sus bienes materiales como en los inmateriales; este paisaje cultural surge por el proceso de hibridación que se da entre lo tradicional/moderno, local/cosmopolita.

- Se plantea que es importante vigilar las políticas y planes que se desarrollen con respecto al Paisaje Cafetero con una mirada holística, y no disgregada, para lograr la sostenibilidad de la declaratoria; de lo contrario, pasará al olvido.

\section{Macroproyecto Pereira Imaginada: Croquis ciudadanos. Caso: imaginarios urbanos con aroma de café, puente de Pereira entre el éxito y el hotel Camino Real}

Autora: Estefanía Concha Ocampo

Año: 2014

\section{Resumen}

La tesis da cuenta de las marcas del paisaje cultural cafetero a partir de las rutinas de los ciudadanos que transitan, viven o se recrean en la carrera 12 bis entre calles 15 y 16 en la ciudad de Pereira, enmarcada dentro del macro proyecto de investigación "Pereira imaginada: 2009-2014", en su tercera fase de microetnografías y archivos públicos. La metodología llevada a cabo fue cualitativa, combinando las categorías propuestas por el investigador Armando Silva, sobre imaginarios urbanos, con sus subcategorías: ciudad, ciudadano y otredades, y los aportes de la etnografía como método de la antropología.

Los resultados obtenidos fueron la identificación de índices de formas de vida de la cultura cafetera como: el yipao cafetero, expresiones artísticas, 
gastronomía, vestuario y accesorios, rasgos religiosos, marcas cafeteras en un croquis pequeño de ciudad.

\section{Palabras claves:}

Imaginarios urbanos, rutinas, marcas, ciudad, cultura cafetera

\section{Descripción:}

La pregunta de la que se partió en esta tesis fue la siguiente: ¿Es posible distinguir marcas del paisaje cultural cafetero en la carrera 12 bis entre calles 15 y 16 en la ciudad de Pereira a partir de las rutinas ciudadanas? La pretensión era buscar huellas de la cultura cafetera en el croquis de ciudad, comprendido en dicho espacio. Esta idea surge como resultado de la investigación sobre Pereira Imaginada 2009, en la cual se identificaron, por parte de los ciudadanos, croquis de ciudad. Esto es, micro espacios que se convierten en lugares importantes para aquellos, ya sea por la rutina de vivirlos diario, o de ser un transeúnte frecuente de dichos espacios. La tesista quiso, entonces, bucear allí, para unir los hilos que aparentemente estaban sueltos y darle sentido a la idea que guía la inmersión: encontrar quizás marcas de la cultura cafetera en ese pequeño lugar.

\section{Metodología:}

La metodología de base fue la etnografía, con la observación participante directa, así como el uso de entrevistas no estructuradas, acompañada siempre por las categorías teórico-metodológicas de los imaginarios urbanos propuestas por el investigador Silva. Para el análisis y lectura de los datos, se tomó la propuesta del grupo de investigación en comunicación educativa, consistente en una mirada trial relacional, donde cada dato adquiere su sentido solo en relación con otros, así, lo aparentemente obvio, no lo es tanto. De esta combinación de técnica y análisis se tomó la triada base siguiente, para organizar y darle sentido al dato: 
Figura 1. Colombia (ícono) Marcas y rutinas ciudadanas (símbolos)

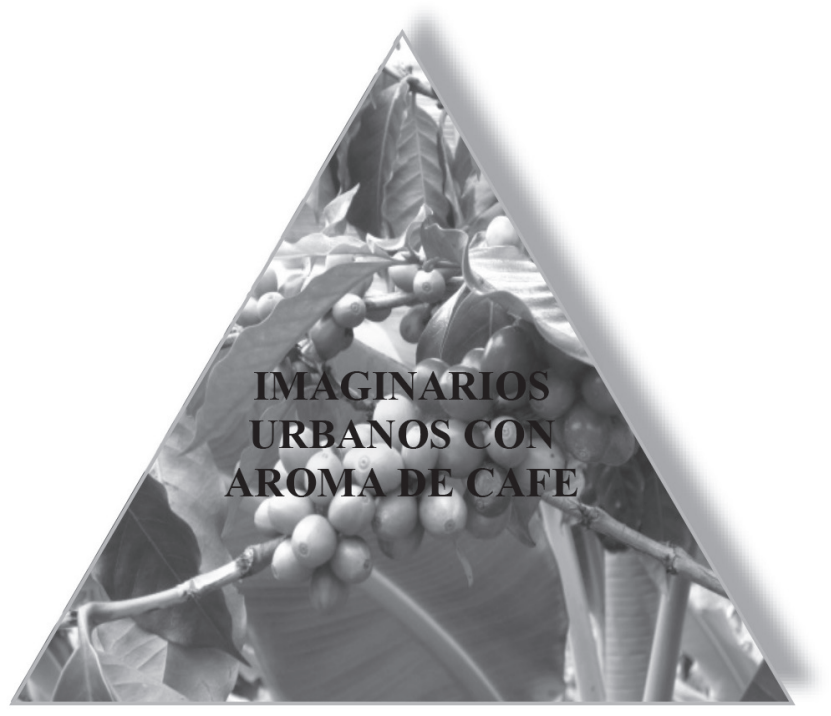

Carrera 12 bis entre calles 15 y 16 Pereira, Paisaje Cultural Cafetero (índices)

Fuente: Concha Ocampo, Estéfani (2014)

\section{Conclusiones}

- La pregunta planteada al principio, fue resuelta positivamente, es decir, en el croquis estudiado se encontraron índices de la cultura cafetera, como el yipao cafetero, expresiones artísticas, gastronomía, vestuario y accesorios, rasgos religiosos. Lo sorprendente es el lugar tan pequeño físicamente donde se vive y recrea dicha cultura. Las personas que viven allí, así lo dejan ver en sus casas tradicionales con construcciones de barro que se conservan aun, el café, símbolo presente en todos los que pasan o trabajan en dicho espacio.

- Otro aspecto central del croquis referido, es el puente que comunica dos ciudades prácticamente, la tradicional y la moderna. La primera corresponde al centro antiguo (galería, parque de Bolívar, gobernación); y la segunda, al lugar que emerge como nuevo centro, desplazando al 
anterior, con los centros comerciales (Pereira Plaza, Arboleda), hoteles (Pereira, Calle Real) restaurantes, zona rosa, que se convierten en atractores caóticos para los ciudadanos.

\title{
Cuerpo imaginado: objeto de ensoñaciones y deseos
}

\author{
Autor: Mercedes Ramos Olaya
}

Año: 2012

\section{Resumen:}

Este trabajo tiene como propósito reconocer los índices de los imaginarios culturales de la mujer que consumen las niñas entre 12 y 16 años del colegio Héctor Ángel Arcila de Pereira, desde las vallas publicitarias. Para este propósito se trabajó la teoría del signo de Charles Sanders Peirce y la teoría de los imaginarios urbanos desarrollada por el colombiano Armando Silva.

\section{Palabras claves:}

Imaginarios culturales, signo, primeridad, segundidad, terceridad, valla publicitaria, comunicación educativa.

\section{Descripción:}

Este trabajo de investigación trata de reconocer los imaginarios culturales de mujer desde las vallas publicitarias; por tanto, se plantea la siguiente pregunta de investigación: ¿Qué índices de imaginarios culturales de la mujer, consumen las niñas entre 12 y 16 años del Colegio Héctor Ángel Arcila desde las vallas publicitarias? La filosofía de la representación y la teoría del signo, desarrolladas por el filósofo norteamericano Charles Sanders Peirce, se constituyen en el marco teórico de esta investigación. El objetivo general es: Determinar los índices de imaginarios culturales que producen las imágenes 
de mujer en vallas publicitarias, para las mujeres del grupo de edad entre 12 y 16 años del colegio Héctor Ángel Arcila; los objetivos específicos son: a) Señalar los índices de los imaginarios de mujer que tienen las niñas con los que ofrecen las imágenes impresas en vallas publicitarias; b) Determinar los estándares establecidos en las imágenes, como estereotipo de mujer y que son asumidas por las adolescentes; c) Comparar los imaginarios culturales y los estándares establecidos por las estudiantes de la Institución Educativa Héctor Ángel Arcila. Las vallas publicitarias se constituyen en el pretexto para reconstruir los imaginarios culturales de las adolescentes en mención.

\section{Metodología:}

La investigación se ubica en el paradigma cualitativo, por lo cual se hace uso de la técnica de recolección de la información denominada grupos de discusión. El proceso de análisis y síntesis del dato, se realiza a través de la técnica relacional creada desde el Grupo de investigación de la Maestría en Comunicación Educativa a partir de los planteamientos filosóficos del norteamericano Charles Sanders Peirce.

\section{Conclusiones:}

- Hay un imaginario cultural de mujer desde las vallas publicitarias que solo es encarnado en el momento en el que ella lo quiera hacer suyo; esto se hace evidente a través de sus gustos y necesidades.

- Los hallazgos hechos nos permiten ver cómo el imaginario cultural se va estableciendo en la medida en que se van posicionando las representaciones de mujer o las necesidades de consumismo en momentos puntuales; esta es la manera como se va creando cultura; en donde los sujetos van creando las imágenes visuales que los alimentan de emociones y que se van proyectando en los otros.

- Abordando la comunicación y la educación como procesos de transformación cultural, se perfila en ellas el interés por buscar nuevas maneras de educar que produzcan cambios en las estructuras sociales para consolidar una sociedad más incluyente. 


\section{Emergencia de la función de innovación en la universidad: el proceso de la Universidad Tecnológica de Pereira}

Autores: María Elena López Montoya, Felipe Vega González

Año: 2012

\section{Resumen:}

Esta investigación se propuso validar, dentro de la problemática de la innovación en el contexto contemporáneo, la hipótesis de la emergencia de la función de innovación en la Universidad Tecnológica de Pereira y la identificación de los factores que la determinan como expresión de la comunicación educativa. Con tal propósito, fue necesario identificar el proceso de reconfiguración de las relaciones de enseñanza - aprendizaje como una de las expresiones fundamentales de la reestructuración misional de la universidad Tecnológica de Pereira, en términos de innovación.

\section{Palabras claves:}

Innovación, producción y gestión del conocimiento, misión de la universidad, función de innovación, redes sociales, aprendizaje social, comunicación educativa, innovación y desarrollo social

\section{Descripción:}

Esta investigación se propuso validar, dentro de la problemática de la innovación en el contexto contemporáneo, la hipótesis de la emergencia de la función de innovación en la universidad y la identificación de los factores que la determinan como expresión de la comunicación educativa. En este contexto, presenta la configuración de redes entre los diversos actores sociales, determinada por el modo en que se crea, se transfiere y se aplica el conocimiento en la época histórica actual, suscitando la necesidad de comprender la dinámica de ese aprendizaje social. La compleja interacción entre universidad, innovación y desarrollo regional, determina 
las condiciones sobre las que está emergiendo la innovación como la nueva función misional de la universidad. La conceptualización de la innovación, los sistemas nacionales de innovación, la innovación como expresión de la comunicación educativa, fueron elementos de sustentación de la comprensión de la dinámica de producción y gestión del conocimiento en el marco de las Ciencias Sociales, dentro de lo que implica en educación, del ingreso en la sociedad y economía del conocimiento y del desarrollo de esta en las regiones dentro de la actual globalización.

\section{Metodología:}

Al ubicarse en la perspectiva cualitativa, es una investigación de tipo documental para lo cual se tomaron como información los planes de desarrollo de la Universidad Tecnológica de Pereira. El análisis de las estrategias y realizaciones de los planes, los alcances de los procesos y proyectos de investigación en los que se comprometió la universidad, constituyeron el estudio de caso para identificar el proceso de reconfiguración de las relaciones enseñanza - aprendizaje como una de las expresiones fundamentales de la reestructuración misional de la universidad.

\section{Conclusiones:}

- La integralidad de la interacción entre el marco teórico, el marco metodológico y el análisis documental que se consideró un rasgo principal del enfoque metodológico utilizado, llevó a confrontar las evidencias documentales con la evaluación y reconocimiento en la práctica de ejecuciones y procesos de institucionalización que pueden refrendar, efectivamente, la hipótesis planteada en el caso de la Universidad Tecnológica.

- El recorrido efectuado por la ejecución y proyección de los planes de desarrollo de la Universidad permite reconocer la emergencia de la función de innovación pero, igualmente, identificar carencias y contradicciones en la perspectiva de la innovación. No bastan los propósitos expresados en los planes para generar las transformaciones requeridas y sobre todo para que emerja efectivamente una nueva universidad. 
- En rigor, el plan formulado al 2019 es aun un propósito por concretar. Deberá estar sometido a una dinámica de confrontación con la realidad, que en un proceso de comunicación educativa podría ir generando las transformaciones que configuren efectivamente la función de innovación, rompiendo con esa universidad que en gran medida solo se mira a sí misma en una labor repetitiva de docencia.

\section{Imaginarios religiosos de Medellín con respecto a las imágenes presentes en las familias}

Autor: Sandra Castaño Rico

Año: 2012

\section{Resumen:}

El objeto de este trabajo es conocer las percepciones, pasiones, emociones, costumbres y sentimientos que tienen en la actualidad los ciudadanos de Medellín con relación a las imágenes religiosas, con el fin de comprender uno de los ámbitos que configura modos de ser urbanos, en este caso particular, los imaginarios que se tejen en torno a la religión.

\section{Palabras claves:}

Religión, imágenes, hogares, fotografía.

\section{Descripción:}

Esta investigación que se adscribe al macroproyecto Medellín Imaginada, emerge inspirada en la tesis realizada por Beatriz Elena Varelo Mazo titulada La multicoloridad de la emotividad religiosa en los jóvenes: caso Alfonso Jaramillo e Instituto La Villa, articulada al proceso de investigación del proyecto Pereira Imaginada; en esta se afirma, que los jóvenes no solo construyen sus percepciones en torno al hecho religioso, sino que elaboran interpretaciones 
que les permiten actuar como protagonistas de la transición social. En este contexto, la investigación propuesta en Medellín no solo cobra vigencia a partir de la premisa de que esta ciudad históricamente se caracteriza por ser religiosa, sino que este fenómeno es un ámbito que configura modos de ser urbanos. Por lo tanto, la pregunta que orienta el proceso de indagación se formula en los siguientes términos $¿$ Es posible definir imaginarios religiosos de Medellín a partir de las rutinas realizadas alrededor de las imágenes religiosas que poseen los ciudadanos en sus hogares? Para dirigir este interrogante, el objetivo general gira en torno a identificar los imaginarios religiosos de los ciudadanos de Medellín a través de las rutinas que realizan alrededor de las imágenes religiosas que poseen en sus hogares; y los específicos en relación a: (i) recolectar, a través de registros fotográficos, las imágenes religiosas que tienen los ciudadanos de Medellín en los lugares sociales dentro de sus hogares; (ii) describir las relaciones que los ciudadanos establecen con las imágenes religiosas"; (iii) inferir los imaginarios religiosos de Medellín a partir de los hallazgos del proyecto. Un trabajo con estas connotaciones aporta a la línea de investigación sobre imaginarios urbanos desarrollada por el investigador Armando Silva Téllez no solo en Colombia, sino en América Latina y algunas ciudades europeas.

\section{Metodología:}

Este trabajo se desarrolla desde la perspectiva del paradigma cualitativo, se emplea la metodología de los imaginarios urbanos y se toma como referencia las imágenes religiosas que poseen los ciudadanos de Medellín una vez se visitaron 20 hogares de diferentes estratos. De manera simultánea al proceso de recolección de información a través de las fotografías tomadas a las imágenes y su respectiva sistematización en fichas de análisis, se elabora una entrevista con el fin de identificar las rutinas que se construyen alrededor de ellas e inferir las temporalidades y las marcas.

\section{Conclusiones}

- Entre las imágenes religiosas más significativas para los ciudadanos entrevistados y visitados en sus hogares en la ciudad de Medellín, se registra Sagrado Corazón de Jesús, María Auxiliadora, la Santísima 
Trinidad, Cristo o la Devoción a la Cruz, el Divino Niño, Niño Jesús en la navidad y El pesebre.

- El estudio visibiliza la interacción que construyen los ciudadanos con los espacios, su diferenciación por género, preferencias, rutinas, gustos y usos que marcan la cultura religiosa en Medellín de forma particular en cada habitante, pero que con el tiempo se hace colectiva.

- Las rutinas urbanas en este estudio se configuran en la puerta de comprensión de los usos que tienen los ciudadanos con las imágenes religiosas, lo cual posibilita conocer el ciudadano que siente y vive la ciudad. En este sentido, es de vital importancia el trabajo de campo acompañado del registro fotográfico y las entrevista ya que se configuran en índices que descomponen las razones por las cuales los ciudadanos poseen en sus casas imágenes religiosas, articuladas a sentimientos y creencias.

\section{Imaginarios de ciudad saludable}

Autor: Néstor Javier Velásquez Bonilla

Año: 2012

\section{Resumen}

El autor de este trabajo es un médico que aborda el tema de los «Imaginarios de ciudad saludable» desde la investigación cualitativa, a partir de elementos tomados de la fase I del macroproyecto "Pereira Imaginada: 2009- 2014". Indaga a los ciudadanos de Pereira para rastrear posibles relaciones entre la Pereira Imaginada y «Estrategia Ciudad Saludable» planteada por la Organización Mundial de la Salud.

\section{Palabras claves:}

Imaginarios, ciudad, salud. 


\section{Descripción:}

Este trabajo emerge de la primera fase de la investigación Pereira Imaginada, liderada por la Maestría en Comunicación Educativa, particularmente, se inspira en las cualidades urbanas que los ciudadanos le asignan a la ciudad a partir de la indagación realizada en torno a la manera como se percibe la ciudad, el lugar de trabajo, las necesidades básicas de Pereira y lo que más agrada y desagrada de la ciudad.

Su pretensión es visualizar la ciudad saludable desde la perspectiva de los imaginarios de los ciudadanos. Para ello, se recurre a la perspectiva teórica de Armando Silva Téllez, y se profundiza en los datos arrojados en la categoría de cualidades urbanas a partir de una entrevista semiestructurada aplicada a un grupo de ciudadanos y a un conjunto de funcionarios oficiales planificadores del sector de la salud en la ciudad de Pereira, con la finalidad de dar respuesta a los tres interrogantes que guían la propuesta de indagación: ¿Cuál será el emblema con que identifica la Salud en Pereira?, ¿Percibe usted a Pereira como una ciudad saludable? y ¿Cómo se imaginaría una ciudad saludable?

\section{Metodología:}

Desde la perspectiva cualitativa este trabajo apropia la metodología creada por el investigador Armando Silva Téllez para la comprensión de los imaginarios urbanos. Como técnica de recolección de información se usó la entrevista semiestructurada para el proceso de recolección de información, y en la interpretación de los datos se recurre a la lógica trial para distinguir las maneras de construir la ciudad saludable por parte de los habitantes de Pereira.

\section{Conclusiones}

- Las pretensiones institucionales de los planificadores respecto de la ciudad saludable se presentan en discordancia y lejanía con los imaginarios y deseos que los ciudadanos pereiranos tienen sobre una ciudad saludable. Por tanto, tal conexión se hace necesaria para articular lo que el autor ha llamado la realidad eco-sistemática de la ciudad. 
- En la propuesta se vislumbran sentires ciudadanos que al ser estudiados más a fondo posibilitarían la construcción de propuestas de salud pública acordes a las necesidades y percepciones de los ciudadanos de Pereira.

- En la ciudad de Pereira el concepto de salud saludable se asocia a aspectos como la organización del transporte, programas de entornos familiares saludables y solidarios, protección ecológica, entre otras medidas, que si bien permiten avanzar en la conceptualización de la categoría, presenta de forma ausente aspectos como la incidencia social de las demandas urbanas asociados al desplazamiento y la migración.

\section{Imaginarios Urbanos en la literatura: Las novelas como fuente de reconstrucción de imaginarios sobre Medellín. Caso: La ciudad de todos los adioses de César Alzate Vargas, El dedo índice de Mao de Juan Diego Mejía y Basura de Héctor Abad Faciolince}

Autor: Nicolás Armando Herrera Díaz

Año: 2012

\section{Resumen}

El propósito del presente trabajo es identificar los imaginarios urbanos que se encuentran en las cualidades, calificaciones y escenarios de ciudad descritos y narrados en las novelas La ciudad de todos los adioses de César Alzate Vargas, El dedo índice de Mao de Juan Diego Mejía y Basura de Héctor Abad Faciolince, tres narraciones en las que el tema de Medellín es recurrente.

Palabras claves:

Medellín, novela, ficción, imaginarios. 


\section{Descripción:}

En términos del autor de este proceso de investigación, si bien la literatura es ficción y estética que recrea los procesos mentales y la creación del autor, a partir de su imaginación, percepciones, ideas y experiencias de vida, también se configura como producto social, en el cual se inscribe su inventor a partir de compartir sentimientos, un tiempo, espacio y deseos colectivos. Desde esta perspectiva la literatura se configura en una fuente documental y archivo ciudadano que alberga entre sus líneas imaginarios urbanos. En este contexto, esta investigación responde al siguiente interrogante: $i \mathrm{~A}$ partir de las cualidades, calificaciones y escenarios descritos y narrados en algunas novelas escritas sobre Medellín en los últimos diez años, es posible identificar imaginarios urbanos? A diferencia de las investigaciones incluidas en la colección de ciudades imaginadas de América Latina y Europa, y de los procesos de investigación liderados por la Maestría en Comunicación Educativa desde la ciudad de Pereira y que hoy se extienden a ciudades como Medellín, este trabajo aun cuando se desarrolla desde la misma categoría conceptual, no se circunscribe en la comprensión de las interrelaciones construidas entre el público de ciudadanos y la ciudad que habitan. En esta ocasión, se dispone de la teoría de los imaginarios urbanos para visibilizar los fantasmas que vivifican y las historias que pueblan las ficciones colectivas que leen y reinterpretan las pinceladas de palabras que se tejen en las novelas.

\section{Metodología:}

Esta tesis se desarrolla desde los parámetros del paradigma cualitativo. Asimismo, se inspira en la metodología de imaginarios urbanos de Armando Silva Téllez y el modelo de lógica relacional para la construcción del dato, desarrollada por el grupo de investigación de la Maestría en Comunicación Educativa. Toma como pretexto semiótico o información las narraciones presentes en las novelas La ciudad de todos los adioses, El dedo índice de Mao y Basura. Finalmente, el autor construye unas plantillas que permiten sistematizar, codificar y proceder a la construcción de dato a partir de los corpus de referencia. 


\section{Conclusiones}

- La literatura adscribe a la ciudad una amalgama de tres colores, acompañada de cualidades según temporalidades urbanas. En la noche Medellín se dibuja como roja pasión, roja sangre y roja muerte, como memoria de la década de los ochenta marcada por el narcotráfico y la violencia. El atardecer es azul, como un sueño de prolongar la vida y la existencia alejada de las tiniebla de la noche. Y el amanecer y el transcurrir de día amarrillo en honor a la resistencia y fuerza que impone el sol radiante y las hojas de los árboles.

- Losautores delas novelasanalizadasasignanalaciudaddosconnotaciones de olor. Los barrios y las periferias de la ciudad se asocian a fragancias tenues y agradables, en ocasiones imperceptibles. A diferencia, del caótico centro del cual se desprenden olores nauseabundos producto de las multitudes, del aumento de la motorización, entre otros.

- Las narraciones literarias que dan cuenta de este estudio visibilizan la construcción simbólica de la historia de Medellín, sumergida en el miedo, el dolor y la tristeza que evoca de manera constante los hechos de violencia e inseguridad que se niegan a morir en la memoria hecha palabra y en algunos sucesos actuales.

\section{Medellín, un recorrido sobre lo oculto en crónicas y reportajes}

Autor: Dora Luz Muñoz Rincón

Año: 2012

\section{Resumen:}

En este trabajo se toman como objeto de referencia las crónicas y reportajes de Medellín con la finalidad de reconocer las concepciones y percepciones que se tejen de la ciudad, a través de los fantasmas, las representaciones y la visión desde los otros que emerge en la literatura y que se convierte en fuente de inspiración para la construcción de imaginarios urbanos. 


\section{Palabras clave:}

Imaginarios urbanos, literatura, Medellín.

\section{Descripción:}

Partiendo de la tesis acerca de que la literatura es una fuente de construcción y recreación de realidad, este trabajo se propone comprender a través de las crónicas "Las mujeres de Pablo García" y "La nostalgia de Lovaina" del libro Medellín es así, crónicas y reportajes del escritor antioqueño Ricardo Aricapa, los imaginarios que emanan de la ciudad de Medellín. En este sentido, responde a la siguiente pregunta ¿Desde los géneros narrativos (crónicas y reportajes), es posible encontrar imaginarios urbanos de Medellín en cuanto a cualidades, calificaciones y escenarios? La propuesta de imaginarios urbanos de Armando Silva, funge como referente teórico. El objetivo general es: encontrar en la forma cómo se narran y describen crónicas y reportajes, los imaginarios urbanos que se esconden, tejen y que no son visibles ni tangibles en el mundo vivo de las palabras: la literatura, que tiene como protagonista a la ciudad de Medellín en sus relatos. Para alcanzar este objetivo, se plantean los siguientes objetivos específicos: (a) Buscar detrás de las palabras, ideas y relatos de crónicas y reportajes escritos sobre la ciudad de Medellín, todo aquello que no es perceptible de entrada, que está oculto (sentimientos, sensaciones, percepciones, necesidades, fantasías, realidades, demarcaciones, lugares, entre otros) y que son representados por medio de la literatura. (b) Identificar en las diferentes crónicas y reportajes sobre Medellín, las cualidades urbanas (primeridades), como signos sensibles (olores, colores, sonidos, lugares, personajes, acontecimientos, situaciones, clima, tiempo, géneros musicales, percepciones, etc.), que caracterizan e identifican a la ciudad y que por medio de sus ciudadanos son representadas, delineadas, hechas imagen y que han ayudado a darle una identidad a la misma. (c) Descubrir desde el género crónicas y reportajes las calificaciones urbanas (segundidades), que los ciudadanos han generado para marcar y valorar a la ciudad de Medellín, las formas como la califican y objetivizan en sus percepciones, apreciaciones y necesidades y las cuales relacionan con diferentes aspectos de la ciudad y sus instituciones. (d) Encontrar en los escritos sobre crónicas y reportajes que tienen a Medellín como protagonista, los escenarios urbanos, sitios o lugares 
(terceridades), en donde los ciudadanos de Medellín actúan y se representan. Espacios de mucha importancia como lo son el amor, la diversión, la comida, el peligro, entre otros y donde los ciudadanos se desenvuelven como actores principales.

\section{Conclusiones}

- Las crónicas analizadas en esta investigación dibujan una Medellín plasmada de cualidades de carácter negativo, que preserva el estereotipo de peligrosa y violenta; el nodo de la redacción son sitios y personajes emblemáticos de la ciudad por estar inmersos en hechos violentos, además de situaciones que narra el autor de la tesis como: narcotráfico, inseguridad, revolución, marginalidad, prostitución, bandas delincuenciales, muerte, exclusión entre otras situaciones vividas en la ciudad.

- Al indagar a los ciudadanos se encuentran algunas relaciones entre la percepciones de estos y las crónicas, sin embargo, no todos los relatos de Medellín que emergen a partir de los ciudadanos se inspiran en los hechos violentos; estos recrean otras vivencias y escenarios que se resemantizan y proyectan otros anhelos y deseos de ciudad.

\section{El mundo perdido de la realidad}

Autor: Germán Augusto Cruz Arizmendi

Año: 2012

\section{Resumen}

El objeto de este trabajo es determinar el concepto de realidad que construyen los Gammers desde la mediación ejercida por los videojuegos. Un estudio enmarcado en procesos de interacción digital aporta no solo en la comprensión sino en la producción de mensajes y estéticas configuradas a partir de códigos 
artificiales del pixel; adicionalmente, requiere de posturas reflexivas de las ciencias humanas y sociales para indagar la simbología de la comunicación.

\section{Palabras claves:}

Infografía, realidad, gamers, videojuego.

\section{Descripción:}

Este trabajo de grado se propone interpretar las formas de representación de realidad. Para ello toma como pretexto semiótico el uso de los videojuegos en tanto mundo que configura lenguajes relacionados con mitologías y fantasías que conducen al sueño a un estado de sensación e interacción. En este contexto, la pregunta que guía la indagación es la siguiente ¿Es posible que los jóvenes Gamers del Centro Comercial "Parque el Lago" de la ciudad de Pereira entre 16 y 20 años de edad, construyan conceptos de realidad a partir de su mediación con el videojuego de rol "World of Warcraft"? El marco teórico se desarrolla a partir del concepto de realidad y semiótica desde Umberto Eco, imagen digital e infografía desde Pierre Lévy e imaginarios simbólicos desde Gilbert Durand. Y los objetivos específicos son: (a) Distinguir índices de realidad dentro de la construcción semiótica diseñada en el videojuego de rol "World of Warcraft". (b) Determinar los íconos de realidad dentro de la narrativa histórica propuesta en el videojuego de rol "World of Warcraft". (c) Comprender representaciones simbólicas de los jóvenes GAMMERS en su mediación con el videojuego de rol "World of Warcraft". (e) Evidenciar los datos usados dentro del desarrollo de la investigación y su análisis a la luz de los conceptos teóricos y metodológicos propuestos.

\section{Metodología:}

La presente investigación está dirigida desde la visión cualitativa. La fuente de información son los Gamers en su medio de videojuego de rol "World of Warcraft”. Y entre las técnicas de recolección de información se emplearon los grupos de discusión, la observación y los diarios de campo. 


\section{Conclusiones:}

- Con este trabajo se aporta al campo de la Comunicación Educativa ya que conceptualiza los escenarios digitales con sus representaciones a fin de profundizar en los escenarios pedagógicos y formativos que puede llegar a tener el uso del videojuego.

\section{De lo azul a lo cálido y popular}

Autora: Lucia García

Año: 2011

\section{Resumen:}

Articulada a la segunda fase del proyecto Pereira Imaginada de la Maestría en Comunicación Educativa, este trabajo de grado se propone leer la ciudad desde la perspectiva de quien habita y vive la ciudad en la zona rural del municipio, en este caso particular, el corregimiento de Alta Gracia.

\section{Palabras claves:}

Altagracia, azul, cálido, popular, rural.

\section{Descripción}

El modelo teórico de imaginarios urbanos de Armando Silva Téllez se propone abordar los modos de ser urbanos de los ciudadanos de las metrópolis y ciudades intermedias. No obstante, este trabajo reconociendo el fenómeno conocido como la "fuga de las ciudades", documentado en el marco de la antropología urbana, en el cual los centros históricos de los poblados se desconcentran y las familias de niveles socioeconómicos altos se desplazan a los extramuros de las ciudades, se propicia la aplicación de la metodología del autor colombiano para conocer las percepciones que sobre la ciudad construyen los habitantes del corregimiento de Alta Gracia. En necesario 
aclarar, que si bien, este es un fenómeno visualizado para las metrópolis, en el caso de Pereira los ciudadanos de Alta Gracia no se han migrado; por el contrario, son habitantes de la zona rural que viven y construyen su interacción con la ciudad a partir de relaciones centro - periferia. Por lo anteriormente expuesto, se formula el siguiente interrogante: ¿Cuáles son las percepciones actuales que sobre la ciudad de Pereira hacen (recrean), y reconocen los habitantes del corregimiento de Altagracia y cuál es su proyección a futuro en relación a la ciudad-cualidades urbanas, ciudadanos temporalidades y otredades-cercanías? En coherencia con la perspectiva teórica se proponen tres objetivos específicos, conducentes al desarrollo de la pregunta; identificar las cualidades urbanas, las temporalidades y las cercanías que los ciudadanos del corregimiento de Altagracia reconocen sobre la ciudad; reconocer el modelo encarnado propuesto por Silva, a través del análisis de la información en relación al concepto de imaginarios urbanos; y finalmente, aportar a los estudios sobre imaginarios urbanos en ciudades intermedias a partir de la actualización y proyección de las percepciones, usos y evocaciones que los habitantes del corregimiento Altagracia Municipio de Pereira realizan sobre su ciudad.

\section{Metodología}

Esta investigación se aborda desde el paradigma cualitativo, teóricamente parte de la aplicación de la metodología elaborada por Armando Silva para el estudio de las ciudades imaginadas, se aplicó el formulario base y luego usando la metodología de la lógica trial fundamentada en la fenomenología peirceana, se logró la construcción y análisis del dato desde las triadas pasando por los nodos, hasta configurar los triadas de sentido.

\section{Conclusiones}

- Este estudio parte de la distinción centro / periferia; sin embargo, entre los imaginarios y las formas de establecer relaciones entre los ciudadanos y la ciudad se puede inferir que el corregimiento de Altagracia se vive no como un par de oposición complementario rural - urbano, sino como una extensión del territorio urbano aun cuando se reconoce que geográficamente el territorio se encuentra en la localidad rural. 
- Existe una continuidad en la proyección de la percepción entre los ciudadanos que habitan en la zona rural y la zona urbana. Al comparar los resultados de la investigación Pereira Imaginada (fase1) ylas evocaciones de los habitantes del corregimiento de Altagracia se identifican aspectos concordantes como el Viaducto, La Plaza de Bolívar, Ciudad Victoria, el tiempo cálido, la música popular, la percepción de una ciudad alegre y peligrosa, entre otras rutinas y marcas ciudadanas. La única excepción existente, se configura en torno al color, en la cabecera municipal los colores que identifican a Pereira son los de su bandera (amarillo y rojo), y en Altagracia corresponde al azul, tonalidad que acompaña techos, puertas y paredes.

\section{Pereira imaginada fase II 2009-2014 ¿La ciudad del deseo o la ciudad del corazón partío?}

Autor: Claudia Ximena Gómez Rubiano

Año: 2011

\section{Resumen:}

Esta investigación se adscribe a la segunda fase del macroproyecto Pereira Imaginada, tiene como finalidad profundizar en las categorías cualidades urbanas y rutinas ciudadanas. Se propone a través del ejercicio etnográfico comparar las rutinas que construyen los ciudadanos de Pereira en los escenarios Zoológico Matecaña, Aeropuerto Matecaña y centro comercial Victoria Plaza con las propuestas de los planes de gobierno local entre el 2005 y el 2011.

\section{Palabras claves:}

Imaginarios urbanos, deseos ciudadanos, primeridad, segundidad, terceridad. 


\section{Descripción:}

En el marco de las investigaciones adscritas a las micro etnografías o micro procesos imaginarios, que desde la perspectiva de Armado Silva Téllez hacen posible aislar un fenómeno urbano a fin de profundizar en el mismo; este trabajo de grado realiza una triangulación entre la información emergente en la primera fase de la investigación Pereira Imaginada, sobre los escenarios Zoológico Matecaña, Aeropuerto Matecaña y centro comercial Victoria Plaza, con las rutinas elaboradas por los ciudadanos en estos escenarios y las propuestas contenidas en los planes de gobierno sobre estos lugares para el periodo 2005 - 2011. En este sentido, se propone responder al interrogante: ¿Se podrían reconstruir los imaginarios de ciudad presentes en la relación ciudadanos y administradores políticos dados en el Aeropuerto Matecaña, el Centro Comercial Victoria Plaza y el Zoológico Matecaña? Este trabajo es importante en primer lugar porque aporta a los estudios sobre imaginarios urbanos desde la visión complementaria entre los planificadores de la ciudad y las prácticas de los ciudadanos; y en segundo lugar, porque presenta un procedimiento para poner en escena microetnografías sobre un aspecto urbano desde la perspectiva de Armando Silva Téllez y las propuestas metodológicas que viene desarrollando la Maestría en Comunicación Educativa.

\section{Metodología:}

Con un enfoque cualitativo, este trabajo hace uso de los diarios de campo para el proceso de recolección de información, así como plantillas de análisis de sistematización. Además de la aplicación del modelo lógico relacional para la construcción del dato y el posterior cruce con la teoría.

\section{Conclusiones:}

- El centro comercial Victoria Plaza presenta una relación de continuidad entre las percepciones y rutinas del público de ciudadanos y las propuestas de gobiernos sobre el mismo, en aspectos como: ampliar la zona de comercio, embellecer la ciudad y generar espacios "seguros". Sin embargo, este centro comercial a diferencia de lo esperado en la 
planeación gubernamental respecto a la disminución de las ventas ambulantes y el comercio ilegal, suple variedad de demandas de los usuarios quienes en muchas ocasiones compran por fuera los dulces, las artesanías y los minutos.

- En la ciudad de Pereira confluyen rutinas urbanas características de las grandes ciudades con otras particulares de poblados rurales, lo que marca una ciudadanía en transición hacia la urbanización.

- El Aeropuerto se configura en un escenario de metáforas de alegría - tristeza, esperanza - ruptura, cercanía - lejanía, en coherencia con una ciudad comercial que ofrece diversidad de productos (pastelería, restaurantes, ropa, artesanías, librerías, entre otros).

\section{Imaginarios urbanos (de ciudad), en el cine de ficción realizado en Medellín de 2000 a 2010}

Autor: Ana Isabel Lopera Agudelo

Año: 2011

\section{Resumen:}

Este trabajo tiene como propósito identificar los imaginarios urbanos de Medellín a través de los largometrajes de ficción realizados en la ciudad entre el 2000 y el 2010. En este sentido, se analizan desde la perspectiva semiótica de Charles Sanders Peirce, con las categorías de icono, índice y símbolo las siguientes películas: La virgen de los sicarios (2000), de Barbet Schroeder, Sumas y restas (2004), de Víctor Gaviria, Rosario Tijeras (2005), de Emilio Maillé, Apocalipsur (2007), de Javier Mejía y Paraíso Travel (2008), de Simón Brand.

\section{Palabras Claves:}

Archivos ciudadanos, cine, imaginarios urbanos, Medellín. 


\section{Descripción:}

Partiendo de la tesis de Eric Rohmer (2000), el cine es ficción, la ficción realidad, y de todas las artes este es el más realista; esta investigación aborda el objeto cine como archivo ciudadano que narra percepciones, sentimientos, acontecimientos y escenarios. Por lo tanto, en el marco de este trabajo se formula la siguiente pregunta de investigación: ¿Es posible encontrar imaginarios urbanos (de ciudad) en el cine de ficción realizado en Medellín del 2000 a 2010? Las categorías conceptuales de semiótica de Charles Sanders Peirce e imaginarios urbanos y archivos ciudadanos de Armando Silva Téllez se configuran en el marco teórico. El objetivo general es: identificar los imaginarios urbanos (de ciudad), en los largometrajes de ficción realizados en Medellín del 2000 al 2010; y los específicos son: primero, leer desde los íconos, índices y símbolos dichas categorías de imaginarios urbanos en los largometrajes de ficción realizados en Medellín durante el periodo escogido; segundo, interpretar desde los planteamientos del imaginario urbano de Armando Silva los posibles imaginarios de ciudad presentes en los largometrajes de ficción realizados en Medellín del 2000 al 2010; y tercero, aportar a los estudios de imaginarios urbanos de América Latina a partir del análisis de las películas tomadas como muestra.

\section{Metodología:}

El enfoque del presente trabajo es cualitativo, tomó como muestra de estudio 5 películas realizadas cuyo tema es la ciudad de Medellín, durante la primera década del presente siglo. En un primer momento se elaboraron unas fichas de recolección de la información usando la técnica de análisis de contenido; y posteriormente, abordan desde la metodología de imaginarios urbanos de Armando Silva y la lógica trial elaborada a partir de la fenomenología de Peirce; en estas películas se buscó distinguir las cualidades, calificaciones y escenarios realizando una lectura desde los íconos, índices y símbolos a dichas categorías. 


\section{Conclusiones:}

- El cine como archivo comunitario posibilita a los habitantes de Medellín construir y recrear la memoria colectiva a través de la narración y evocación de situaciones vividas en un momento de la historia de la ciudad como el sicariato, el narcotráfico, narcoterrorismo, el enriquecimiento ilícito y el secuestro.

- El imaginario "de la eterna primavera" pervive en las películas. Los largometrajes presentan siempre una ciudad de clima templado; de las cinco películas analizadas solo en la Virgen de los sicarios y Rosario Tijeras se recrean algunas escenas bajo la lluvia.

- Las películas analizadas se circunscriben al género drama. En la primera década del siglo XXI, el cine en Medellín estuvo ausente de las comedias, del terror y del amor. Si bien este último está presente en Rosario Tijeras y Sumas y restas sus directores no se atrevieron a trabajar en otro género. Lo anterior se corresponde con un deseo de tipo realista, que permite a través de la ficción narrar pasajes, hechos y circunstancias vividas por los ciudadanos.

\section{Cibernautas y la Medellín Imaginada: Entre el ethos y el tanathos}

Autor: Nora Elena Botero Escobar

Año: 2011

\section{Resumen}

Este trabajo de grado se adscribe al macroproyecto Medellín Imaginada de la Maestría en Comunicación Educativa, adscrita al convenio entre la Universidad Tecnológica de Pereira y la Universidad de Medellín. La aserción que se presenta es la siguiente: "el estereotipo paisa es una construcción cultural que se realimenta y exalta como valor de primer orden a través de 
los videos promocionales de Medellín”; para ello, las categorías conceptuales abordadas corresponden a los archivos públicos y los imaginarios urbanos, y el objeto de referencia corresponde a los comentarios elaborados por los cibernautas en el portal de Internet "YouTube" que promocionan a Medellín.

\section{Palabras claves:}

Cibernautas, Medellín, YouTube

\section{Descripción:}

La reflexión que se adelanta en esta investigación dimensiona la categoría imaginario como productor y movilizador del efecto social, que a su vez configura y sustenta los hábitos y prácticas ciudadanas. En este horizonte, se plantea la siguiente pregunta de investigación ¿Es posible construir imaginarios urbanos de Medellín a partir de la ciudad cercana, lejana y anhelada que se expresa implícita y explícitamente en los comentarios que los cibernautas realizan sobre los videos encontrados en el portal YouTube que promocionan a Medellín? Los videos objetos de análisis son: "Medellín eterna primavera", "Medellín Going global”, "Medellín Medellín- Del miedo a la esperanza", "Colombia Medellín Pues", "Welcome to Medellín”; estos fueron subidos en la red desde diferentes lugares del mundo como los Estados Unidos, España y Colombia. Es importante resaltar, que a partir del plan de marketing 2006 -2016 inaugurado en la alcaldía (2004) de Sergio Fajardo con el nombre "Medellín, donde la creatividad florece", la ciudad ha iniciado a través de las redes sociales y del internet, en general, un proceso de internacionalización que presenta índices de otras percepciones de ciudad que se alejan del imaginario del miedo y la inseguridad como lo van reflejando los cibernautas que plasman sus pensamientos y opiniones. Ahora bien, desde la perspectiva teórica de los archivos públicos de Armando Silva Téllez, este trabajo aporta a la formulación de políticas públicas que permitan visibilizar ciudades más incluyentes, de manera que acojan múltiples y ricas visiones de otredad y que respondan a deseos colectivos. 


\section{Metodología:}

Este trabajo se lleva a cabo a partir del enfoque cualitativo y del modelo de lógica relacional que interrelaciona la elaboración de las triadas, los nodos y las triadas de sentido, a partir del corpus emergente de los comentarios de los cibernautas en el portal YouTube que promocionan a Medellín.

\section{Conclusiones:}

- Los videos de You Tube están acompañados de una serie de comentarios que no solo recrean, sino que crean y encarnan en el otro y en el ciudadano un sentir colectivo alrededor del imaginario de "raza paisa". Sin embargo, este se construye a partir de una serie de conceptos etnocéntricos que se manifiestan en expresiones como: "Medellín la mejor ciudad del mundo", "los paisas son los mejores" y otros que llaman la atención de la autora, al concebirlos como necesidad de reconocimiento de tipo social hiperbolizado, que requiere ser objeto de reflexión, ya que exhorta el riesgo de sentirse el centro de universo negando la diferencia y al otro.

\section{Construcción de ciudad desde la temporalidad plural en transporte público. Pereira imaginada 2009 - 2014}

Autor: Luz Marina Hurtado Tabares

Año: 2011

\section{Resumen}

Esta investigación emerge a partir de la aplicación del formulario base de la metodología imaginarios urbanos de Armando Silva Téllez, en la primera fase de la investigación Pereira Imaginada. Pretende profundizar en el área ciudadanos, en la categoría temporalidad y en la temática transporte público, con el fin de problematizar la relación entre las políticas de los planes de 
gobierno y los intereses y necesidades del público de ciudadanos que habita la ciudad.

\section{Palabras claves:}

Ciudad, temporalidad, transporte público.

\section{Descripción:}

Este trabajo se propone la observación y reconstrucción de las percepciones de los ciudadanos de Pereira en torno a la temporalidad vivida al interior de los desplazamientos en el transporte público; con la finalidad de distinguir los imaginarios que soportan los conceptos e imágenes de ciudad. Para ello, se propone la siguiente pregunta de investigación: ¿Podemos aportar a la reflexión de imaginarios urbanos con el concepto y la imagen de ciudad que se origina en los habitantes de Pereira, durante la temporalidad plural del recorrido en transporte público? El abordaje se realiza retomando algunos elementos de la filosofía, específicamente, el concepto de tiempo simultáneo y temporalidad plural de Julián Serna Arango, la construcción de realidad de Humberto Maturana y la concepción de imaginarios urbanos de Armando Silva Téllez. Desde la perspectiva del Área Metropolitana del Centro Occidente (AMCO), el estudio se delimita al transporte colectivo masivo, a los buses, busetas y articulados; adicionalmente, aporta en la mirada de complementariedad entre la concepción del administrador planificador del servicio que oferta a la ciudadanía y los intereses, temores y necesidades del ciudadano que habita la ciudad.

\section{Metodología:}

Esta es una investigación de enfoque cualitativo, teóricamente construida desde la metodología de imaginarios urbanos de Silva, y en particular, desde las temporalidades de los ciudadanos de Pereira. En la recolección de la información se hizo uso de la técnica de los diarios de campo y una entrevista estructurada, posteriormente, la información recolectada se codificó y se analizó haciendo uso de la lógica trial para procesar y llegar a la respuesta formulada en la investigación. 


\section{Conclusiones}

- Todas las acciones vividas al interior del transporte masivo, el tiempo de espera y los recorridos confluyen en la configuración de las temporalidades plurales de los ciudadanos que tejen miradas de ciudad.

- La desterritorialización de las ciudades como fenómeno característico de los urbanismos ciudadanos se ve representada en la temporalidad plural del transporte público. Los recorridos del transporte masivo, si bien están demarcados físicamente al interior de la ciudad, transcienden la extensión sensorial, la ciudad se desborda a si misma a través de los pensamientos, ideas e interpretantes que se tejen sobre el espacio habitado a través del movimiento que se experimenta dentro y fuera del transporte masivo.

\section{Medellín imaginada desde la televisión. Los imaginarios en la serie de televisión "muchachos a lo bien"}

Autores: César Alonso Cardona Cano y Mauricio Andrés Álvarez Moreno Año: 2011

\section{Resumen}

Esta investigación se proponer identificar los imaginarios de la ciudad de Medellín en la década de 1990, a partir de la serie televisiva "Muchachos a lo Bien", emitida otrora por el canal regional Tele Antioquia, desde la perspectiva de los archivos ciudadanos de Armando Silva Téllez.

\section{Palabras clave:}

Televisión, imaginario, Medellín. 


\section{Descripción:}

Esta investigación parte de la afirmación de que el archivo ciudadano "Muchachos a lo bien", a través de su estructura narrativa de contar historias de personas y de comunidades de Medellín, pretende desatar valores, reconstruir el tejido social y reconciliar a los ciudadanos, a partir de la proyección de aspectos de la vida cotidiana de los habitantes alternos a la violencia, el secuestro, el narcotráfico, etc. Es así, que se cree que esta pieza audiovisual rompe con los estereotipos que cobraron fuerza en la ciudad hacia la década de 1980, y que en muchas otras narrativas como el cine y la literatura se niegan a morir. Con esta premisa de entrada, los autores de la tesis se proponen elaborar una observación metódica al contenido urbano presente en la serie televisiva con el fin de identificar los imaginarios urbanos de la Medellín de 1990. El marco teórico se construye desde Armando Silva y Néstor García Canclini a fin de poner a dialogar los archivos urbanos, el lenguaje audiovisual y los modos de ser contemporáneos.

\section{Metodología:}

Esta investigación dialoga entre el paradigma cualitativo y cuantitativo de la investigación. La información se toma de la narrativa audiovisual de la serie "Muchachos a lo Bien". Y el dato se construye a partir del modelo de análisis trial.

\section{Conclusiones}

- La narrativa de la serie televisiva "Muchachos a lo Bien", recrea una Medellín de dos colores. Una gris que retrata la marginación, la inoperancia del gobierno, las injusticias sociales y todas las rutinas ciudadanas que se alimentan de la pulsión de la muerte, mientras marcan la condición pública de la ciudad. Y una Medellín naranja que connota la condición de intimidad de los hechos del hogar en el cual se construyen las relaciones de familiaridad y amistad.

- La investigación Medellín Imaginada desde la Televisión, si bien visibiliza el contexto de violencia y marginalidad, presenta índices del ciudadano que sobrevive a la contrariedad. 
- Este trabajo aporta conceptualmente a la perspectiva antropología de la sociabilidad, en tanto corriente de estudios sobre la ciudad y el fenómeno urbano; que marca como los ciudadanos después de estar expuestos a desastres de tipo natural o condiciones de extrema violencia, construyen formas de organización y demanda social.

\section{Vitrineando la semiótica de los imaginarios urbanos de la ciudadela cuba}

Autor: Consuelo Orozco Giraldo

Año: 2011

\section{Resumen}

Este trabajo emerge de la primera fase de la investigación Pereira Imaginada 2009- 2014. Enfatiza en el área ciudad y en la categoría temporalidad, particularmente, en el carácter de los ciudadanos como alegres, serenos, melancólicos y agresivos según el modelo trial de análisis de las metrópolis de Armando Silva Téllez.

\section{Palabras clave:}

Imaginario, Cuba, carácter de los ciudadanos.

\section{Descripción:}

La ciudadela Cuba, en el marco de los imaginarios urbanos, presenta una lectura diferencial para el público de ciudadanos según el lugar de residencia. Entre los principales lugares de violencia se registra Cuba para los ciudadanos que no habitan en ella; caso contrario emerge con la asignación alegre y casi no violenta para quienes viven allí. En el marco de esta lectura, esta investigación se propone la siguiente pregunta: ¿Qué hechos en los escenarios 
y configurados en las temporalidades, superponen los croquis de alegría y violencia sobre la ciudadela Cuba? Interrogante abordado desde los micro procesos imaginarios postulados por el doctor Armando Silva Téllez, que permiten aislar un tema para identificar sus variantes de funcionamiento según los niveles de invención fantasiosa.

\section{Metodología:}

El presente trabajo se desarrolló desde la investigación cualitativa. Entre las técnicas de recolección de información se emplearon la entrevista, la observación directa en las calles y el anecdotario (diario de campo). Se hizo uso de la metodología lógica relacional para la construcción del dato.

\section{Conclusiones}

- Las transformaciones del parque Guadalupe Zapata y la Estación Central de Megabús, indicen en la asignación de cualidades ciudadanas que propician en sus transeúntes demandas de tranquilidad y acogida en el espacio. Esto hace que la autora del trabajo culmine el mismo generando nuevos interrogantes para complejizar la respuesta a la pregunta inicialmente planteada: ¿Cómo se están transformando los imaginarios del barrio 2500 lotes? ¿Qué hechos en los escenarios están transformando la violencia en paz? ¿Qué movimientos o rutinas ciudadanas están transformando los imaginarios? ¿Cuáles son sus croquis afectivos y qué los produce? ¿Cómo son los archivos de este barrio, especialmente, los privados como el álbum de familia? 


\section{Marcas ciudadanas: Una mirada al gusto de los pereiranos}

Autor: Roberto Enrique Vásquez Murillo

Año: 2011

\section{Resumen:}

Este trabajo emerge del macroproyecto Pereira Imaginada. Tiene como finalidad abordar, en la categoría marcas ciudadanas, los aspectos que más gustan de la ciudad, a través de una microetnografía elaborada con jóvenes de 11 a 16 años del Colegio la Salle de Pereira.

\section{Palabras clave:}

Marcas, percepción de gusto, imaginario.

\section{Descripción}

El desarrollo de esta tesis parte de las terceridades producto de la investigación de la primera fase del macroproyecto Pereira Imaginada: 2009-2014, en este sentido, se propone contrastar las representaciones sobre las marcas enunciadas por los ciudadanos en el trabajo referido con las construidas por los jóvenes al indagar por aquellos aspectos que más les gustan de la ciudad. Por lo tanto, responde a la siguiente pregunta ${ }_{¿}$ Es posible distinguir imaginarios del gusto por la gente en los jóvenes entre 11 - 16 años del Colegio de la Salle Pereira? Conceptualmente, se desarrolla desde la perspectiva de la fenomenología de Charles Sanders Peirce y la metodología de imaginarios urbanos de Armando Silva Téllez.

\section{Metodología:}

La presente tesis está enfocada desde la investigación cualitativa. La fuente de recolección de información corresponde a 30 estudiantes del colegio La Salle entre los 11 y los 16 años de edad. La técnica de recolección es un formulario con preguntas cerradas y preguntas abiertas inspirado en la metodología de 
imaginarios urbanos de armando Silva Téllez. La lógica relacional se emplea a partir del modelo de triadas, nodos y triadas de sentido para la construcción del dato.

\section{Conclusiones:}

- En las respuestas de los estudiantes del Colegio La Salle que participaron en el proceso de recolección de información, se identifica una serie de sentires y deseos de alta concentración simbólica en las cualidades que se asignan a los ciudadanos de Pereira, entre ellas: "trabajadores, de buen humor, alegres, cordiales, amables, buenas personas y normales". Estas calificaciones que se configuran en emblemas, tienen como punto determinante el género masculino. Por su lado, aspectos como el "café, las mujeres "fáciles", Megabús, pocas oportunidades, humilde, desempleo, descuidada" se presentan como dispersión tanto para hombres como para mujeres, además del punto de vista hijos de personas que viven en Pereira después de procesos de migración de grandes ciudades.

- De manera similar a la investigación Pereira Imaginada, en este proceso de investigación los jóvenes identifican a Medellín como ciudad con afinidad a Pereira y anhelada.

\section{La radio y los imaginarios urbanos en Medellín: de lo semiótico y lo ideológico a la configuración del imaginario social del paisa. Caso de las noticias de Radio Paisa}

Autor: Frank Piedrahita Bedoya

Año: 2011

\section{Resumen}

En esta investigación se analiza un archivo ciudadano de tipo comunitario, obtenido a partir de la radioemisora, Radio Paisa, adscrita a la Radio Cadena 
Nacional, RCN, con la finalidad de distinguir índices que solidifican la categoría cultura paisa. La información requerida para el análisis se obtiene de los efectos sonoros, de la voz, de la música y, por su puesto, del discurso presente en el noticiero matutino y meridiano de la Radio Paisa, entre junio y octubre de 2010.

\section{Palabras clave:}

Radio, imaginario, cultura paisa.

\section{Descripción}

A través de su historia, la radio, por su carácter simbólico, ha tenido la posibilidad de mantener, proyectar y consolidar ideas sociales en diferentes generaciones. Esta característica se asocia, por un lado, a la particularidad de acompañamiento en el ámbito de la intimidad del hogar; y fundamentalmente, por su aparente don de ubicuidad que la identifica en el lugar de los hechos. De manera adicional, se encuentra la potencialidad que tiene este medio de comunicación al estar limitado al sonido, no solo para afectos dela imaginación, sino para acompañar otras rutinas debido a la movilidad que comporta. Desde la perspectiva de imaginarios de Armando Silva Téllez, este medio se configura en archivo comunitario que puede ser objeto de análisis desde esta perspectiva. Por lo tanto, la pregunta orientadora de esta investigación es: ¿Podremos encontrar índices que refuercen la categoría cultural paisa en la ciudad de Medellín, en el programa informativo, Las Noticias de Radio Paisa, de la Radio Cadena Nacional, RCN?. En consonancia con lo anterior, el objetivo general se adscribe a la tarea de identificar aquellos índices que, desde la perspectiva sonora, representan la subcultura paisa en el imaginario colectivo urbano de la ciudad de Medellín, y que la reafirman a partir de variadas expresiones sonoras (archivos), difundidas en un medio público, masivo como el radial, perceptibles a través de un programa informativo en una radioemisora de arraigo popular local, como las noticias de Radio Paisa. Para gestionar lo anterior los objetivos específicos son: (i) Identificar marcas de lo cultural paisa en los discursos orales, las expresiones musicales y sonoras que se emiten en el programa Las Noticias de Radio Paisa. (iii) Determinar escenarios de lo cultural paisa, hallados en las piezas sonoras y 
musicales usadas en la emisión del programa Las Noticias de Radio Paisa. (iii) Establecer relaciones entre diferentes categorías de análisis, que evidencian una temporalidad y unas rutinas de lo cultural paisa en el programa las noticias de Radio Paisa. (iv) Identificar los anhelos, las afinidades y las lejanías implícitas en los efectos sonoros, las expresiones verbales y musicales, que se emiten en dicho espacio radial y que permiten a sus audiencias evocar sus imaginarios de lo cultural paisa y reafirmar su identidad, así como establecer relaciones entre las cualidades y las calificaciones de lo cultural paisa en las expresiones verbales, musicales y sonoras emitidas en el programa las noticias de Radio Paisa.

\section{Metodología:}

El presente trabajo es de enfoque cualitativo y hermenéutico. Los materiales de primer orden a través de los cuales se construyen las observaciones de segundo orden son las noticias de la Radio Paisa, a partir de las cuales se construyeron en primer lugar, las plantillas de sistematización y organización de la información; y, posteriormente, se emplea la lógica relacional para la construcción de dato.

\section{Conclusiones}

- Entre los índices hallados se identifica el componente religioso de la cultura paisa, que con frecuencia es utilizado para justificar diversos fines; incluso de forma contradictoria es empleado, en términos de la autora de la tesis, como comodín para ir en contra de los mismos principios de la doctrina católica.

- La cultura paisa es calificada como tradicionalista y conservadora; adicionalmente, marca en el hombre una condición progresista ajustada a las estructuras de lo social. La familia se registra como una de esas estructuras que estimula la laboriosidad con el fin de mejorar las condiciones de vida de esta. Asimismo, la familia se constituye en el escenario de preservación de principios y valores en torno al carácter de la personalidad, por lo tanto, no es ajeno que se marque de manera constante la idea del hogar como regazo donde se juega su futuro y el de toda su estirpe. 


\section{Imaginarios de una Medellín en blanco y negro ciudadanos de hoy leyendo a los ciudadanos de ayer: fotografías del centro de Medellín}

Autor: Diego Augusto Arango Bustamante

Año: 2011

\section{Resumen:}

El objeto de esta investigación es conocer los imaginarios de Medellín a partir del archivo fotográfico denominado "Transeúntes" que conserva imágenes callejeras que demarcan el ayer de la ciudad. Este trabajo se aborda desde la fenomenología de Charles Sanders Peirce, la teoría de los imaginarios urbanos y la concepción de archivo de Armando Silva Téllez.

\section{Palabras clave:}

Medellín, Transeúntes, imaginarios urbanos, archivo.

\section{Descripción:}

Tomando como pretexto semiótico los álbumes de variados hogares de Medellín y del Valle de Aburrá, fotografías realizadas otrora por los fotocineros caracterizados por usar las cámaras Olympus Pen para captar a los transeúntes de las calles del centro de Medellín y espacios emblemáticos de la ciudad, este trabajo se propone comprender la transformación del centro de Medellín a partir de la imágenes de la década de los sesenta y setenta. Para ello, el interrogante que guía la investigación es el siguiente: ¿Es posible encontrar en las fotografías tomadas por los fotocineros en las calles de Medellín en la década de los años 60 y 70 del siglo XX, algunos índices que permitan identificar escenarios que puedan ser considerados como lugares imaginados de la ciudad? Para guiar el desarrollo de la pregunta el objetivo general es: recuperar la memoria visual urbana de Medellín en una época estimada entre 1960 y finales de 1970, a través del producto comercial de la 
fotografía de los transeúntes que visitaban el centro de Medellín y que fueron registrados por los fotógrafos callejeros, reconocidos como fotocineros. Y los objetivos específicos: (a) Analizar y clasificar diez fotografías representativas del centro de Medellín, pertenecientes al archivo fotográfico Transeúntes. (b) Determinar los imaginarios urbanos sobre la Medellín de las décadas del sesenta y setenta entregadas por los encuestados y contrastarlas con los imaginarios generados por estas personas sobre Medellín en la actualidad. (c) Encontrar imaginarios que señalen anhelo, afinidad y lejanía sobre los escenarios, marcas y rutinas de Medellín en las décadas del sesenta y setenta y contrastarlas con los imaginarios de la ciudad en la actualidad. (d) Construir croquis urbanos que ofrezcan mapas y rutas sobre los imaginarios urbanos de Medellín.

\section{Metodología:}

Con un enfoque cualitativo y la metodología de los imaginarios urbanos, se emplea la entrevista, la encuesta y la fotografía como técnicas de recolección de información. Posteriormente, se procede a la sistematización a través de plantillas de análisis de la información construidas por el autor. Se culmina el proceso metodológico empleando los tres estadios de la lógica relacional: construcción de triadas, nodos y tríadas de sentido.

\section{Conclusiones:}

- Las fotografías albergan una variedad de escenarios, personajes, actividades y acontecimientos urbanos que demarcan un "presente -presente" en el imaginario colectivo de los habitantes de Medellín. Si bien cada fotografía narra la década de los sesenta y los setenta adscribiéndose al pasado, estas han transmutado al hoy como se percibe a través de la evocación de los ciudadanos.

- Escenarios como la vía Junín se convierten en referente de tradición familiar, lugar de diversión, disfrute y cotidianidad para la generación que antecede a los jóvenes. Mientras otros encarnan las transformaciones que demarcan las transiciones de la ciudad, como es el caso de la carrera Carabobo y el Parque Norte que otrora se configuraban en índice de decadencia y hoy polos de vida cultural. 
- Los pasajes comerciales recreados en las fotografías del centro de Medellín son evocados con cualidades como oscuros, de tránsito y artificiales que demarcan rutinas de antaño, hoy sustituidas por las prácticas vividas en los centros comerciales y los "malls".

\section{Discusión de la metáfora como terceridad en los procesos de comunicación de la ciencia, la tecnología y la innovación en la Universidad Tecnológica de Pereira}

Autor: Carlos Andrés Botero Girón

Año: 2011

\section{Resumen}

Este trabajo se propone analizar, con el enfoque semiótico presente en la teoría del signo de Charles Sanders Peirce y en la categoría de metáfora de Emmanuel Lizcano, la información que contiene los resultados de ciencia, tecnología e innovación de la Universidad Tecnológica de Pereira, publicados en medios de comunicación escritos en la ciudad de Pereira.

\section{Palabras claves:}

Signo, metáfora, ciencia, tecnología e innovación, Universidad Tecnológica de Pereira.

\section{Descripción}

Desde la perspectiva de la terceridad de Charles Sanders Peirce y el concepto de metáfora en Emmanuel Lizcano, en esta investigación se analizan los procesos de comunicación de la producción sobre ciencia, tecnología e innovación de la Universidad Tecnológica de Pereira, publicada en el Diario de la Tarde durante los años 2008 - 2009. Para ello, se distinguen los signos 
recreados, a partir de un corpus de 15 titulares de prensa, por un grupo de ciudadanos, de los cuales, unos no tienen formación en educación superior y otros sí la poseen. En este sentido, el enfoque semiótico devela una disonancia entre las terceridades de los titulares del medio impreso, y las ideas emergentes tanto en el grupo de las personas con y sin educación superior. Lo anterior se configura en un índice de distanciamiento entre el papel de la universidad en la generación de tecnología, ciencia e innovación y el uso, apropiación y socialización de la misma en el público de ciudadanos externo al ámbito universitario. De lo anterior, emerge una propuesta comunicativa basada en la metáfora no solo para socializar el conocimiento en y por fuera de la universidad, sino como puente que transforma el imaginario y, por lo tanto, posibilita la construcción sígnica.

\section{Metodología:}

Con un enfoque de investigación mixta, se interrelaciona la lectura semiótica de los contenidos de las informaciones relacionadas con la ciencia, la tecnología y la innovación en la Universidad Tecnológica de Pereira, con la aplicación de una encuesta a personas con y sin educación superior, a fin de correlacionar las emocionalidades generadas a partir de los titulares de prensa, en tanto objeto de indagación.

\section{Conclusiones}

En el marco de la socialización de los resultados de ciencia, tecnología, e innovación de la Universidad Tecnológica de Pereira en medios impresos de la ciudad, se visibilizaron dificultades en los procesos de comunicación.

El lenguaje empleado para la difusión de los resultados de la ciencia, la tecnología y la innovación no posibilita la construcción de un representamen que establezca relaciones entre los signos empleados para la difusión y el objeto que representa cada uno. Lo anterior, aumenta la disyunción entre el papel de la universidad en la generación de conocimiento y la apropiación y uso que el público de ciudadanos con formación y sin formación universitaria puedan hacer de esta, como un índice de calidad de vida.

En relación con lo anterior, emerge una propuesta para la comunicación 
de la ciencia, la tecnología y la innovación articulando la categoría de metáfora en Lizcano y la categoría de terceridad en Peirce, como elementos indispensables en el uso del leguaje requerido para ampliar el mundo de posibilidades en la construcción de signos en relación con los temas - objetos de la difusión del conocimiento.

\section{Medellín en subjetiva: Visión de los Ciber/YouTube/Anos. Estudio de caso: contribución a los archivos urbanos}

\section{Autora: Silvia Elena Córdoba González}

Año: 2011

\section{Resumen:}

Esta investigación se aproxima a la multiplicidad de subjetividades captadas y plasmadas en las pantallas por los ciudadanos de Medellín a través de la herramienta YouTube, en torno a su ciudad usando los medios digitales de los que disponen. Este trabajo se aborda desde la perspectiva de la ciudad imaginada de Armando Silva Téllez y la fenomenología de la representación de Charles Sanders Peirce.

\section{Palabras claves:}

Medellín, video, tecnologías, digitalización, narración audiovisual, YouTube.

\section{Descripción:}

En el presente trabajo se hace un abordaje teórico a un conjunto de productos audiovisuales elaborados por los ciudadanos de Medellín, que han hallado en el internet $y$, en particular, en YouTube la posibilidad de dejar una impronta donde les es posible, además de reproducir sus visiones y estilos, también volver su subjetividad un material que perdura en el tiempo dadas las características mismas del hipermedia; configurándose la Medellín representada en una ciudad que también habita en el medio digital y es accesible ya no solo desde territorios físicos geográficos sino también desde cualquier parte del mundo, aportando a construir la memoria de su ciudad. 
Es una propuesta para el análisis estético de los productos audiovisuales de la gente, desde la teoría de los imaginarios urbanos, abordando desde dicha mirada teórica toda la maraña de sentido-s que los medellinenses despliegan en la red acerca y desde su ciudad. Cada registro visual no solo alberga una representación de la ciudad, sino que configura el cúmulo de las temporalidades, marcas y rutinas de los ciudadanos que denotan modos de ser urbanos.

\section{Metodología:}

Este trabajo se ubica desde el enfoque cualitativo y hermenéutico, usa la teoría de imaginarios urbanos de Armando Silva Téllez que a la vez se nutre de la filosofía de la representación de Charles Sanders Peirce para el análisis de las piezas de video usadas como muestras para el estudio propuesto.

\section{Conclusiones}

- El video como fuente de representación permite captar lo que piensan los habitantes de Medellín sobre su ciudad, en él se proyectan las temporalidades, marcas y rutinas que delinean los imaginarios urbanos que, sobre un territorio, tejen los ciudadanos. Al tiempo que se configura en un espacio de deseos colectivos, pensamientos e ideas expresados por cada una de los cibernautas.

- En el proceso de indagación, se sugiere que el periodo temporal de cuatro meses de análisis de los videos etiquetados con la palabra Medellín y colgados en el portal de YouTube, permite encontrar asuntos parciales sobre la permanencia de los imaginarios urbanos. Lo cual indica, que si la investigación se realizara en un espacio más prolongado se podrían visibilizar, de manera contundente, las concurrencias en el tiempo de los eventos de la ciudad y el grado de frecuencia de uso que le asignan los habitantes en el espacio virtual.

- Medellín, ciudad capital objeto de referencia de la cultura colombiana no solo funge como punto de mira de las relaciones que se tejen en la vida cotidiana de sus ciudadanos, otrora oral y escrita, sino que en la actualidad navega a través de los contenidos digitales en internet, 
situación que replica al mundo como lo afirma la autora "las estéticas recreadas de Medellín".

\title{
Medellín crónicas: una mirada desde sus imaginarios urbanos
}

\author{
Autor: Daniel Felipe Calle Álvarez
}

Año: 2011

\section{Resumen:}

La tesis que se desarrolla en esta investigación es la siguiente: las crónicas y reportajes archivan imaginarios urbanos expresados en cualidades, calificaciones y escenarios de ciudad, concretamente, Medellín (1980-2008). En coherencia con la aserción mencionada, la perspectiva teórica está tejida en los planteamientos de los archivos urbanos de Armando Silva Téllez.

\section{Palabras claves:}

imaginarios urbanos, crónica, reportaje, Medellín.

\section{Descripción:}

Este trabajo se inscribe en el macroproyecto Medellín Imaginado, desde la perspectiva de los archivos urbanos como espacios y lugares desde donde se crean y recrean imaginarios de ciudad. Por tanto, se plantea la siguiente pregunta de investigación ¿Es posible identificar imaginarios urbanos de la ciudad de Medellín a partir de cualidades, calificaciones y escenarios de ciudad presentes en la producción literaria de género crónica y reportaje: Diario de un pillo (2008), No nacimos pa' semilla (1990) y La verdad sin calzones (2008)? Una investigación con estas características contribuye al estudio del fenómeno urbano en América Latina, cada vez que permite dibujar las múltiples formas como sus ciudadanos perciben y viven su ciudad. El trabajo 
expuesto aquí, presenta índices de la configuración de los imaginarios de violencia e inseguridad que habitan a Medellín, al distinguir en las crónicas condiciones de vida a las cuales se enfrentan los ciudadanos como droga, música, bandas criminales, instituciones educativas, micro-tráfico de drogas, bandas y jóvenes, pobreza, barrios populares, domicilio popular y guerra urbana.

\section{Metodología:}

La investigación realiza un acercamiento desde el enfoque cualitativo, partiendo de la premisa de que la realidad es una construcción socialcolectiva; en articulación con la metodología elaborada por Armando Silva Téllez, visibiliza los imaginarios urbanos a partir de una selección de crónicas y reportajes de Medellín. De allí la edificación del dato a partir de una sistematización inicial del mismo en unas plantillas de recolección de información y el análisis del mismo desde la metodología relacional propuesta por grupo de investigación en Comunicación Educativa.

\section{Conclusiones}

- Los imaginarios urbanos de la ciudad Medellín recreados en las crónicas y reportajes coinciden con algunas de las vivencias de los habitantes. Los diferentes escenarios visibilizados a través de la construcción del dato, como la violencia, los homicidios, los robos, las bandas en los barrios populares, entre otros, que narran problemáticas de la vida social, configuran un imaginario de Medellín como una ciudad en guerra, que encuentra sus raíces en la década de los ochenta y que se niega a morir, afectando principalmente a los jóvenes y los ciudadanos de los diferentes niveles socioeconómicos.

- Las crónicas y reportajes, en tanto archivo urbanos, se configuran en fuente de experiencia ciudadana creadora y recreadora de imaginarios urbanos, que logra encarnar y encarnarse en la percepción colectiva, fungiendo en términos de Silva (2007) como un "antídoto a la perdida de la memoria" y en palabras de Derrida (1995) "terror mismo a la destrucción". 


\section{Pereira imaginada 2009 - 2014. Rutinas Ciudadanas: Una mirada comunicativa de los imaginarios urbanos en el espacio virtual de los jóvenes entre 12 y 16 años de la Institución Educativa Ciudadela Cuba}

Autor: Manuel Andrés Ospina Lozada

Año: 2011

\section{Resumen}

Este trabajo hace parte de la fase II del Proyecto Pereira Imaginada, por tanto, sigue la línea de trabajo de este proyecto. Su objeto es establecer croquis e identificar los imaginarios urbanos referentes a las rutinas de los jóvenes en internet.

\section{Palabras clave:}

Internet, comunicación, entretenimiento, Facebook, jóvenes.

\section{Descripción}

En el año 2009 la Maestría en Comunicación Educativa, puso en escena la primera fase del macroproyecto Pereira Imaginada, articulado a la colección de ciudades imaginadas de América Latina y Europa del Dr. Armando Silva Téllez. La investigación visibiliza modos de ser urbanos en la ciudad de Pereira, entre ellos, la rutina denominada "uso del artefacto cultural computador" para la comunicación y el entretenimiento, además del internet como escenario ciudadano virtual. En este contexto, se plantea la siguiente pregunta de investigación: ¿Es posible distinguir rutinas ciudadanas en la comunicación y el entretenimiento virtual, mediados por la internet, en los jóvenes pereiranos entre 12 y 16 años, de nivel socioeconómico 1 y 2, de la Institución Educativa Ciudadela Cuba? La concepción teórica se desarrolla desde la perspectiva trial de Charles Sanders Peirce, además del concepto de cibercultura de Pierre Lévy y la metodología de imaginarios urbanos presente 
en la colección enunciada anteriormente. Con estos planteamientos de base, el objeto del trabajo se direcciona hacia la distinción de las actividades que los jóvenes realizan en la web, sus rutinas de comunicación y entretenimiento. Este trabajo es importante, ya que no solo indica las prácticas en el espacio virtual, sino que suscita reflexiones en torno a las posibilidades de orientar el uso de las nuevas tecnologías de la información y la comunicación hacia un aprendizaje significativo y autónomo, lo cual propicia fortalecer la práctica docente, y los lazos entre los cibernautas y el ámbito escolar.

\section{Metodología:}

La investigación operacionaliza desde el paradigma cualitativo el formulario base de la metodología de imaginarios urbanos del Dr. Armando Silva Téllez empleado en la primera fase de Pereira Imaginada. Adicionalmente, se adapta el formulario para el proceso de recolección de información a fin de ahondar en los modos de ser urbano a partir de las rutinas en el ciberespacio. Y finalmente, se procede a la construcción de triadas, nodos y triadas de sentido para la construcción del dato.

\section{Conclusiones:}

- Internet propicia en los jóvenes dos dinámicas. Por un lado, formas de comunicación, y por el otro, maneras de construcción de realidades donde la necesidad de estar en contacto con sus congéneres o con ajenos, sea vía chat y el MSN se configuran como rutina y parte de la cotidianeidad de estos nativos digitales.

- La frecuencia de uso de conexión a internet es de 2 horas día, para acceder a formatos multitarea, jugar y comunicarse con amigos y familiares. Entre los escenarios principales se identifica a Facebook, MSN y chat. Entre estos Facebook se ha configurado como una terceridad que sirve de puente, de enlace entre la ciudad virtual y los cibernautas. Y la ciudadanía de los nativos digitales es doble: está la local en la ciudad física de su cotidiano cara a cara y la global cuando están conectados. 


\title{
Modelos de consumo: El caso de las mujeres protagonistas de la telenovela "Las muñecas de la mafia"
}

\author{
Autor: Verónica Llamosa Pérez
}

Año: 2011

\section{Resumen:}

En esta investigación se aborda el fenómeno del consumo, desde la perspectiva de Néstor García Canclini como factor que produce cambios y transformaciones cuantitativas y cualitativas, reflejadas en el actuar cotidiano de los ciudadanos. El pretexto semiótico objeto de análisis fue tomado de la telenovela colombiana "Las muñecas de la mafia", a partir del papel que establecen las mujeres protagonistas con la categoría de referencia.

\section{Palabras claves:}

Las Muñecas de la Mafia, consumo, mujer.

\section{Descripción:}

Desde la perspectiva de consumo del autor latinoamericano Néstor García Canclini y el enfoque del análisis de contenido de los textos televisivos del ONTEL (Observatorio Nacional de Televisión), en este trabajo se propone comprender la categoría consumo, tomando como referente de investigación las protagonistas de la telenovela "Las muñecas de la mafia". Ellas aportan unos estereotipos femeninos que reflejan, en cierto modo, la interacción con la sociedad en la que se habita, visto así, las mujeres involucradas en el narcotráfico son objeto de consumo. Pero aproximarnos desde los modelos de consumo de García Canclini, implica realizar un análisis desde las necesidades naturales y construidas, integrando las disciplinas de lo social, la antropología y la sociología con la comunicación, a fin de visualizar el intercambio de códigos y los cambios cualitativos y cuantitativos que ocurren en la sociedad a través de este fenómeno. En este sentido, la pregunta de investigación que 
orienta el proceso es la siguiente: ¿Se pueden identificar cambios cualitativos y cuantitativos en el consumo en las mujeres protagonistas de la telenovela "Las muñecas de la mafia"?

\section{Metodología:}

El enfoque teórico y metodológico de este estudio está construido a partir de los seis modelos de consumo y la caracterización que Néstor García Canclini hace del concepto, en el ejercicio de comprensión de la sociedad actual. Con un enfoque cualitativo se usó la técnica de análisis de contenido para sistematizar y analizar la información y luego haciendo uso de la lógica trial se procede con la interpretación del dato.

\section{Conclusiones:}

- La cotidianeidad que vemos y vivimos responde a unos cambios que pueden ser comprendidos en su análisis desde los modelos de consumo propuestos por Néstor García Canclini, esta vez se usó una novela, una ficción, como objeto de estudio, pero puede ser aplicable a diferentes referentes semióticos.

- Las mujeres no son espectadoras de la realidad, son parte integrante de la sociedad y por lo tanto, generadoras de códigos que conllevan cambios sociales, si bien el enfoque propuesto es una forma de aproximación a la comprensión del fenómeno, se requerirá de una visión complementaria entre la economía, la antropología y la sociología para su estudio.

- Tomar distancia de la concepción del consumo como relación entre las necesidades y los bienes creados para suplirlas, permite dimensionar esta categoría en el sentido de demanda cultural y práctica creada por los ciudadanos para responder a transformaciones y resemantización de símbolos y rituales configurados por los seres humanos para interactuar o relacionarse con ellos mismos y con los entornos habitados. 


\section{Síntesis}

En esta línea de investigación sehacen relevantes tres conceptos: comunicación, educación y ciudad. El abordaje de tales conceptos, se fundamenta en las ideas de continuidad y complementariedad; por lo que se toma conciencia de los desplazamientos teóricos y metodológicos que han evidenciado términos como disciplinariedad, interdisciplinariedad y transdisciplinariedad.

Tradicionalmente, en el ámbito de las ciencias, se había pensado que los diferentes objetos de estudio se tenían que adaptar a las disciplinas que les correspondían. En tal sentido, se pensaba que un objeto de estudio particular, se correspondía a una disciplina particular; eliminándose la posibilidad de la complementariedad entre diferentes perspectivas teóricas, diferentes metodologías y diversos objetos de estudio.

La continuidad entre comunicación, educación y ciudad lleva a pensar en la posibilidad de la transversalidad de los objetos de estudio en el marco de las diferentes perspectivas teóricas y metodológicas. Esta forma de abordaje trae consigo la relativización de la supremacía disciplinar con el propósito de distinguir nuevas posibilidades en los interregnos que trae consigo la mirada transdisciplinar; de esta manera se pierde en términos de la demarcación de límites e identidades específicas, pero se gana en comunicación y en el alumbramiento de mundos emergentes y posibles. 
Capítulo 3 



\section{Línea de investigación: Nuevas Tecnologías para la Educación}

\section{Nuevas Tecnologías para la educación}

Esta línea de investigación tiene como propósito abordar la articulación de las nuevas tecnologías de la información y la comunicación a los procesos de enseñanza y aprendizaje. Las preguntas que suscitan la realización de investigaciones en el marco de esta línea son las siguientes: ¿Es posible realizar una articulación no instrumental de las nuevas tecnologías a los procesos educativos? ¿La articulación de las nuevas tecnologías a la educación supone desplazamientos de los conceptos de enseñanza, aprendizaje, evaluación, entre otros? ¿La relación entre nuevas tecnologías y educación supone transformaciones en los modos del conocer? 
A continuación el lector encontrará algunos trabajos que tienen implícitos los anteriores interrogantes. Dichas investigaciones tienen como característica central el abordar la relación nuevas tecnologías y educación desde una perspectiva no instrumental.

\section{Macroproyecto: Validación de propuesta educativa con investigación basada en diseño}

Autoras: Alba Inés Rojas Hurtado, Luz Adriana Jiménez, Diana Isabel Peña Osorio

Año: 2014

\section{Resumen:}

El proceso de validación de las propuestas, el concepto past simple tense, Concepto de genética, Concepto la materia y sus propiedades, consistió en profundizar los procesos cognitivos, comunicativos y tecnológicos, a partir del desarrollo de prácticas educativas integradas con las Tecnologías de la Información y Comunicación (TIC). El objetivo central fue construir, implementar y validar una propuesta educativa no lineal con investigación basada en diseño (Barab y Squire (2004), Conole (2012), Wang y Hannfin (2005), utilizando herramientas tecnológicas. El enfoque del estudio se fundamentó en el constructivismo (César Coll, 2004), donde el estudiante es protagonista de su propio aprendizaje, y el conectivismo (Siemens (2004)).

El estudio se validó con 124 estudiantes, entre niñas y niños, en edades comprendidas, entre 13-17 años.

Los resultados arrojaron que los estudiantes, antes de participar en la propuesta (pretest), tenían vacíos cognitivos, en cuanto al contenido puesto en experimentación (genética, materia y sus propiedades y el past simple tense); en el trabajo en equipo y relaciones entre los compañeros; y finalmente, era incipiente el conocimiento amplio de la tecnología. Todos estos vacíos lograron subir su rendimiento, como lo muestra el postest. 


\section{Palabras claves:}

Currículo no lineal, constructivismo, conectivismo, validación, el concepto past simple tense, Concepto de genética, Concepto la materia y sus propiedades.

\section{Descripción}

Las preguntas que orientaron las tesis giraron en torno a ¿Qué procesos cognitivos, comunicativos y tecnológicos se generan en los estudiantes, a partir de la implementación de una propuesta educativa no lineal con investigación basada en diseño para la enseñanza del concepto de Past Simple Tense a través de la plataforma educativa http://dianaisabelpena.wix. com/basic-english-course; la enseñanza del concepto Genética Básica http:// albainesrojas.wix.com/geneticabasica; la enseñanza del concepto la materia y sus propiedades a través de la plataforma virtual http://uza1398.wix.com/ aventurasescolares?

El enfoque del estudio se fundamentó en el constructivismo (Coll, 2004), donde el estudiante es protagonista de su propio aprendizaje, y el conectivismo (Siemens (2004)).

\section{Metodología}

La metodología se llevó a cabo en cuatro fases:

La fase 1 consistió en la revisión del estado del arte de estudios relacionados con la investigación basada en diseño y currículos no lineales, donde se hicieron pocos hallazgos. Posteriormente, se seleccionó el grupo de estudio (124 niños-as de tres instituciones de la ciudad de Pereira). Luego se procedió a indagar sobre los conocimientos previos que los estudiantes tenían sobre el concepto a desarrollar (Past simple tense), Genética Básica, la materia y sus propiedades. El manejo básico de las herramientas tecnológicas y los procesos comunicativos observados en la práctica educativa, mediante la aplicación de un pretest.

La fase 2 tuvo como objetivo principal el diseño de los contenidos a desarrollar en las diez sesiones proyectadas para la validación de la presente propuesta educativa, desde un enfoque cognitivo, tecnológico y comunicativo. 
La fase 3 implicó el diseño y selección (para cada sesión de trabajo) de los recursos tecnológicos apropiados para el desarrollo de competencias a nivel cognitivo, tecnológico y comunicativo de los estudiantes, partiendo de las cuatro habilidades necesarias para el análisis.

Durante la fase 4 se llevó a cabo la aplicación de la propuesta. Tras el acopio de las experiencias, interacciones, aportes de los estudiantes y la dinámica misma de cada sesión de enseñanza-aprendizaje, se hizo la respectiva retroalimentación de los contenidos con el fin de mejorar el diseño de los mismos y así lograr la validación del estudio a partir de los conceptos teóricos inmersos en la didáctica y la pedagogía:

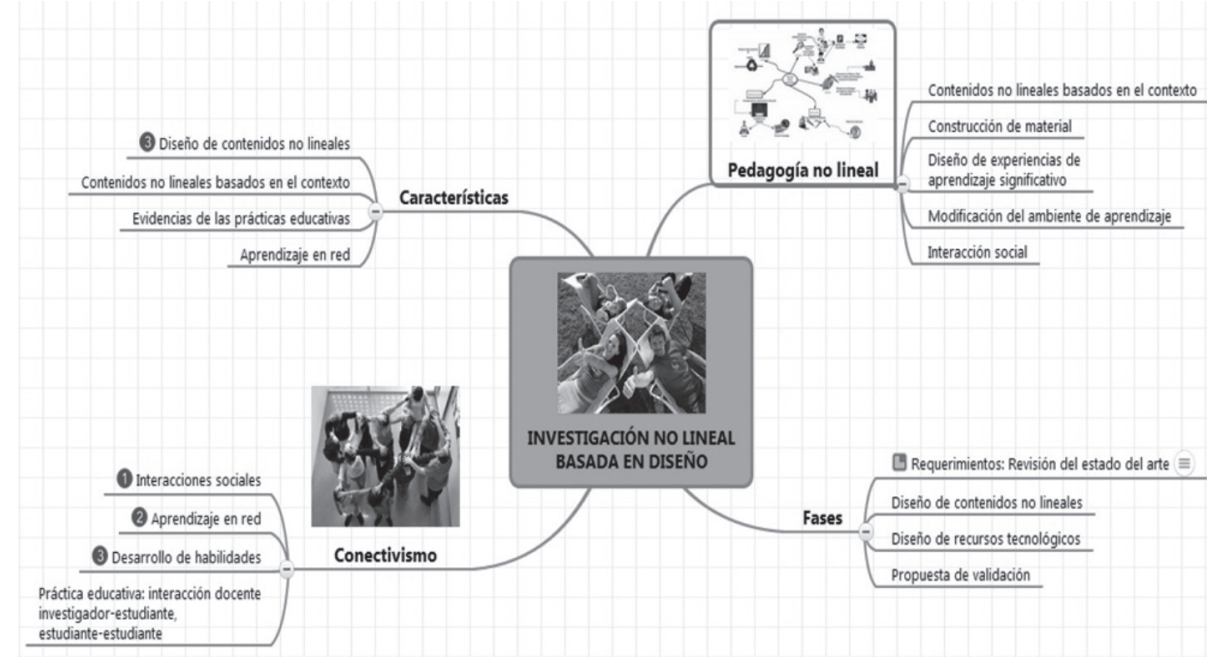

Fuente: Elaboración propia; Peña, Diana Isabel (2014)

\section{Conclusiones:}

- En cuanto al análisis de los resultados arrojados en el pretest y en el postest se demostró que los estudiantes lograron los objetivos de la propuesta en cuanto al conocer y comprender los conceptos de los contenidos propuestos. Es así como el 100\% de los estudiantes se ubicó en un nivel alto en comparación con el pretest, donde el 50\% se ubicó en un nivel medio, en tanto que el resto se ubicó en un nivel 
bajo, pero lo más relevante fue que los estudiantes disfrutaron del proceso de aprendizaje, por lo que se sintieron participes en adquirir el conocimiento, sin embargo, cabe resaltar que el enfoque de la presente propuesta no lineal basada en diseño es de tipo cualitativo, por lo que se enfocó en verificar de manera holística los procesos a nivel cognitivo, tecnológico y comunicativo que surgieron en la aplicación de la misma.

- Los conocimientos previos que tienen los educandos, adquiridos durante la práctica pedagógica y la vida cotidiana, se hacen fundamentales en el momento de impartir una metodología educativa, como punto de partida para enlazar los conocimientos existentes con los nuevos.

- Los diversos colores, fotos, videos, canciones, íconos, enlaces e imágenes en movimiento diseñadas en la página de la propuesta, contribuyeron a incrementar la motivación de los estudiantes a lo largo de este proceso de enseñanza-aprendizaje. Asimismo, crearon un ambiente divertido y creativo de aprendizaje para los estudiantes y la docente de inglés.

- Cuando los jóvenes acceden a la red de forma orientada, entran en actividad intelectual y además pueden estar en comunicación con una gran cantidad de personas, lo queles permite intercambiar experiencias y conocimientos sobre un tema, aspecto que representará la construcción del aprendizaje de manera más sólida y significativa.

\section{Identificación de Categorías toulminianas en clase de filosofía a nivel de educación media con nuevas tecnologías}

Autor: Jorge Iván Hoyos Morales

Año: 2010

\section{Resumen:}

Este trabajo de investigación establece la relación entre la adquisición de habilidades argumentativas siguiendo el patrón toulminiano y el uso del 
software educativo Argusofía. Para ello, se hace uso de las teorías de la lógica factual enriquecida y del aprendizaje significativo por recepción.

\section{Palabras claves:}

Argumentación, lógica factual enriquecida, competencia argumentativa, didáctica de la argumentación, aprendizaje significativo, didáctica de la filosofía, tecnologías de la información y la comunicación.

\section{Descripción:}

En la presente investigación se interrelacionan tres campos de estudio que interesan a la Comunicación Educativa como son la comunicación, la educación y las nuevas tecnologías. Para tal efecto se propone un soporte teórico llamado lógica factual enriquecida, que integra algunos enfoques de la moderna teoría de la argumentación que han tenido gran incidencia entre los comunicólogos; se pone como eje didáctico el desarrollo de las habilidades para identificar las categorías o partes presentes en un tipo de texto argumentativo siguiendo el patrón toulminiano, en especial, la identificación de la pretensión o tesis; y se recurre a una estrategia didáctica fundamentada en el aprendizaje significativo por recepción, que incluye un software basado en la lógica factual enriquecida, llamado Argusofía, a través del cual se puede desarrollar y potenciar la habilidad en mención. El problema de investigación que se aborda, parte de la dificultad que se observa cuando los estudiantes analizan textos argumentativos y de las escasas propuestas didácticas en torno a la enseñanza de la argumentación según lo manifiestan reconocidos expertos en el tema. Lo que se pretende es determinar la manera en que varía la habilidad para identificar las categorías toulminianas después del uso del software educativo Argusofía.

\section{Metodología:}

La metodología propuesta es de tipo experimental correlacional, ya que se observó la correlación entre la habilidad para identificar la pretensión y el uso de Argusofía. Para ello se implementó una estrategia metodológica 
donde se buscaba que los estudiantes aprendieran a identificar las categorías toulminianas usando el software en mención.

\section{Conclusiones:}

- De acuerdo con los resultados obtenidos, se puede decir que el uso de Argusofía contribuyó positivamente al desarrollo de esta habilidad y en mayor grado, en relación con los estudiantes que utilizaron otro tipo de software. Es importante decir que tanto el planteamiento teórico, como la estrategia didáctica y el software desarrollado son contribuciones del autor a una de las líneas de investigación de la Maestría en Comunicación Educativa de la Universidad Tecnológica de Pereira, como lo es la presencia de las nuevas tecnologías en la educación. En este sentido, el presente trabajo es un proyecto de Comunicación Educativa que responde a la necesidad de un espacio educativo determinado. Por otra parte, los temas abordados tienen amplias perspectivas de desarrollo a nivel pedagógico, académico, social y tecnológico.

\section{Síntesis}

En el marco de esta línea de investigación se delimitan los conceptos de técnica, artefacto y tecnología con el propósito de abordar este último en su condición de concepción de realidad, para desmarcarlo de la mirada instrumental de la que es objeto desde algunas perspectivas. Entender la tecnología como concepción de mundo, implica distinguirla en relación de continuidad con sus pares técnica y artefacto.

Así las diversas concepciones de mundo asociadas a tecnologías como la oralidad, la lecto - escritura y lo digital, suponen un saber hacer específico (técnica), y unos soportes físicos que les corresponden (artefactos). La mirada instrumental, focaliza en unos casos la técnica y en otros el artefacto, ubicando en segundo plano la cosmovisión asociada a la tecnología; tal segmentación, hace perder sensibilidad para preguntarse por las transformaciones en el aprendizaje que traen consigo las transiciones tecnológicas.

Una mirada transdisciplinar sugiere abordar los fenómenos socio - culturales contemporáneos desde la continuidad que implican tales procesos. En este 
sentido oralidad, lecto - escritura y lo digital no son concepciones de mundo excluyentes, sino que se compenetran permitiendo nuevos tipos de relaciones que alumbran nuevas formas de ser y de estar en el mundo, especialmente, en la educación; por lo tanto, abordar la relación entre nuevas tecnologías y la educación supone focalizar el aprendizaje como categoría central y, en tal medida, interrogarse acerca de las nuevas relaciones comunicativas emergentes a la dupla enseñanza - aprendizaje.

\section{Mirada relacional}

Consideramos pertinente cerrar este libro tomando como punto de referencia el concepto de observación de segundo orden propuesto por el teórico alemán Niklas Luhmann (2005). Lo planteado bajo este concepto, nos permite dimensionar, de manera adecuada, la pretensión de realizar un trabajo como Modos de Ver III. Los sentidos de la Comunicación Educativa.

Nuestro propósito no es el de hacer una mera relación de los trabajos de investigación quehan realizadolos estudiantes de la Maestría en Comunicación Educativa en un determinado periodo de tiempo. Pretendemos apuntar a la posibilidad de dimensionar la manera en que los autores de los diferentes trabajos seleccionados abordan los fenómenos que son investigados.

Observar observaciones es una afirmación que puede dar cuenta del procedimiento que realizamos para la materialización de este trabajo. Y justamente el teórico Luhmann, deviene esta afirmación en concepto bajo la óptica de su teoría de los sistemas sociales.

Según este autor, la observación consiste en un procesamiento de selecciones que derivan en una distinción entre aquello que se actualiza y aquello que se deja en la opacidad en el mencionado proceso (Luhmann, 1995: 99). Esto quiere decir que la observación, tal como la entiende el autor de referencia, no puede dar cuenta omniabarcante de lo observado, por el contrario, parte de un punto ciego gracias al cual puede ver unas cosas, pero no otras.

En un primer umbral, la observación no hace conciencia de las distinciones que realiza entre actualidad y potencialidad y, por tanto, no distingue el punto 
ciego del que parte y que permite delimitar lo construido en términos de dicha observación. Esto es lo que Luhmann denomina observación de primer orden (1995:100), atribuyéndole como principal característica el que, al estar totalmente focalizado en lo observado, el observador no está en capacidad de distinguir las distinciones de partida (Luhmann, 1995: 102).

¿El proceso del observar se agota en lo descrito en las líneas precedentes? O $¿$ Es posible realizar una observación que permita distinguir el punto ciego del que se parte? ¿Es posible distinguir distinciones? ¿Observar observaciones? Luhmann, plantea un segundo umbral de observación en el que es factible observar la manera en que observan otros observadores. Esto es lo que el autor en mención denomina observación de segundo orden (Luhmann, 1995: 105).

En términos de este autor, la observación de segundo orden es como una observación de primer orden que tiene como rasgo fundamental observar las distinciones de las que parten las diferentes observaciones (Luhmann, 1995: 105). Por tanto, este proceso de segundo orden permitiría dar cuenta de la manera en que se construye la realidad a través de parcelaciones de la misma.

En un sentido operativo, la observación como proceso discriminante supone seleccionar solo unos aspectos de lo observado, dejando por fuera otras posibilidades. Lo no seleccionado no es inexistente, por el contrario, cobra suma importancia al momento de realizar una observación de segundo orden, pues da información importante acerca de los puntos ciegos que suscitan los diferentes esquemas de referencia de los observadores.

Es como si el observador contara con múltiples posibilidades, de las cuales solo puede seleccionar algunas, según se lo permita el punto ciego del que parte. Distinguir la relación entre las múltiples posibilidades seleccionables y la selección realizada por el observador es altamente significativo por cuanto permite comprender la manera en que la realidad es construida a través de la observación en tanto proceso discriminante.

Los conceptos de medio y forma desarrollados por Luhmann, permiten comprender este proceso. El medio es como una especie de compilación de unidades dispersas que son susceptibles de ser relacionadas y combinadas de diferentes maneras. Dichas unidades dispersas, no oponen resistencia a las múltiples posibilidades de combinación, por lo que potencian la 
posibilidad de darle forma a "algo" en términos infinitos. Cómo se generan unas combinaciones y no otras, es cuestión de los esquemas de referencia suscitados por el punto ciego del observador.

La forma es, entonces, el resultado de la particular cohesión y estructuración que asumen las unidades dispersas, según sean las disposiciones del observador. Es de aclarar que las posibles maneras de combinar las formas son bastante altas en términos cuantitativos. El alfabeto y las palabras que construimos a partir de la combinación de las letras que lo constituyen es un buen ejemplo para comprender la relación medio / forma. Las 27 letras del abecedario se constituyen en el medio y las palabras en las posibles formas que son el resultado de los millones de combinaciones que son susceptibles de realizarse.

La forma contiene al medio, en la medida en que lo actualiza y le da existencia. La forma puede constituirse en medio en la medida en que funja como objeto de observación por parte de un observador. Esto aplica, de manera especial, para el caso de la observación de segundo orden en la medida en que el observador se focaliza en las formas construidas por otros observadores. Una concepción tal sobre la observación, tiene profundas implicaciones en cuanto a lo que por ella se ha concebido tradicionalmente en la cultura occidental:

- La observación se realiza en el mundo por parte de observadores concretos.

- Al ser realizada por observadores concretos, la observación supone el trazo de unos límites específicos que suscitan la relevancia de unas unidades y la opacidad de otras.

- La observación, entonces, no da cuenta del mundo tal como este se nos muestra, sino de los esquemas de referencia suscitados por los puntos ciegos del observador.

- De lo anterior deriva el carácter significativo de la observación de segundo orden, pues permite distinguir las diversas maneras en que se procesan las selecciones del observador. Esto acerca al criterio de reflexividad en investigación. 
- El hacer conciencia de que en el proceso del observar quedan aspectos en la opacidad, sugiere reconocer la importancia de estos, en la medida en que dan información importante acerca de la manera en que el observador construye la realidad.

En este orden de ideas ¿Es posible realizar una observación de segundo orden de los trabajos de investigación realizados por los estudiantes de la Maestría en Comunicación Educativa? ¿Se puede distinguir lo que funge como medio para que los estudiantes del programa en mención hagan sus respectivas selecciones con el propósito de construir su trabajo de investigación?

Con respecto a la primera pregunta, aseveramos que la importancia de este trabajo radica en que permite reconocer los esquemas de referencia desde los cuales se construyen los diferentes trabajos de investigación que aportan a la construcción de la comunicación educativa como campo de conocimiento emergente. En relación con la segunda pregunta, podemos afirmar que el medio tiene una constitución tripartita: 1) las diferentes teorías de la comunicación, la educación y la cultura; 2) las tres líneas de investigación del programa de formación y; 3 ) los diferentes objetos de estudio pertinentes al campo de la comunicación educativa. Estos tres referentes cuentan con unidades dispersas que al ser combinadas de múltiples formas, posibilitan la concretización de los diferentes trabajos de grado referidos en páginas precedentes.

A continuación vamos a plantear algunas conclusiones sobre este proceso que se estructurarán a partir de la distinción de tres esquemas de observación: a) perspectivas teóricas elegidas, b) perspectivas metodológicas implicadas; y c) objetos de estudio seleccionados.

\section{Esquema de observación 1: Perspectivas teóricas elegidas}

Las categorías abordadas en cada una de las investigaciones referidas en este libro, dan información importante con respecto a las perspectivas teóricas elegidas en el marco de la Maestría en Comunicación Educativa. 


\section{Categorías conceptuales:}

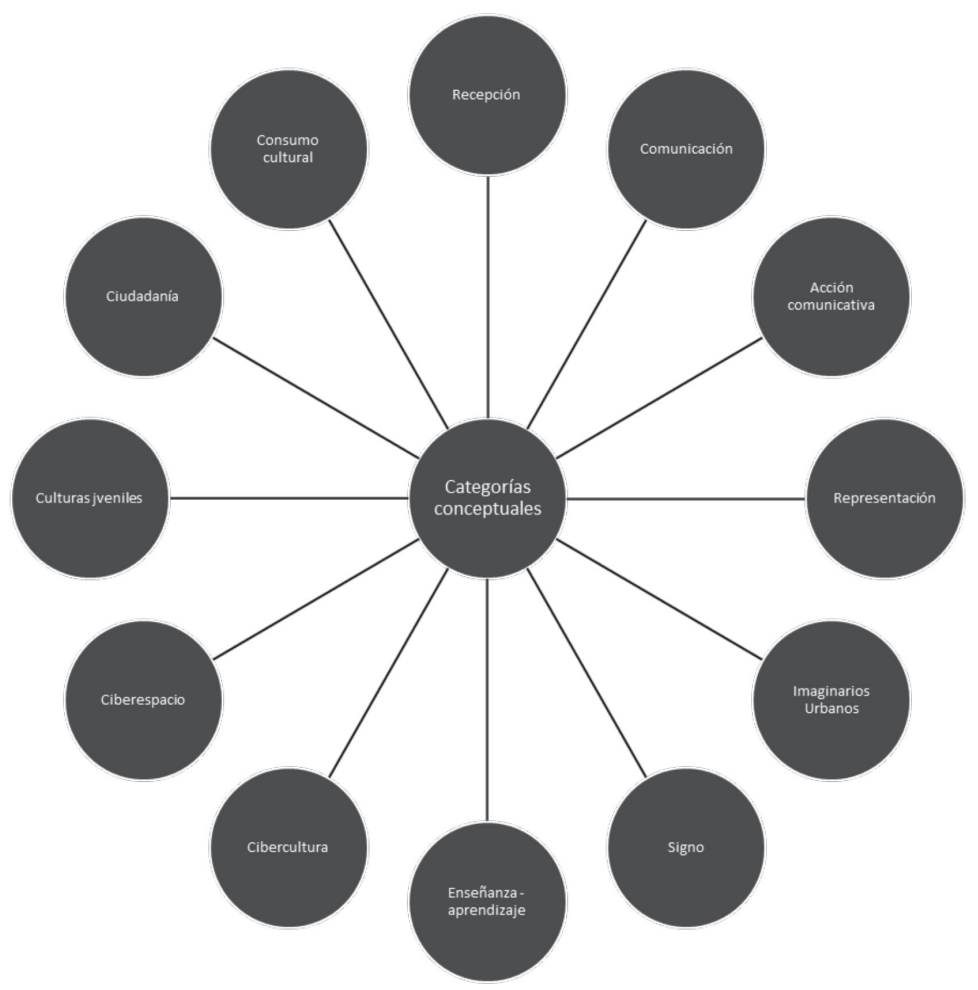

Las anteriores categorías son conceptualizadas desde las perspectivas teóricas desarrolladas por diferentes autores provenientes de escuelas de pensamiento de América Latina, América del Norte y Europa.

\begin{tabular}{|l|l|l|l|}
\hline \multicolumn{1}{|c|}{ Autor } & \multicolumn{1}{|c|}{$\begin{array}{c}\text { Categoría } \\
\text { abordada }\end{array}$} & \multicolumn{1}{|c|}{ Escuela de Pensamiento } & \multicolumn{1}{c|}{ Procedencia } \\
\hline $\begin{array}{l}\text { Charles Sanders } \\
\text { Peirce }(1839-1914)\end{array}$ & $\begin{array}{l}\text { Representación, } \\
\text { Signo }\end{array}$ & $\begin{array}{l}\text { Fenomenología de Pierce, } \\
\text { pensamiento tríadico, pragmatismo. }\end{array}$ & Estados Unidos \\
\hline $\begin{array}{l}\text { Gilbert Durand } \\
(1921-2012)\end{array}$ & Imaginarios & $\begin{array}{l}\text { Círculo de Eranos Perspectiva } \\
\text { arquetípica de los imaginarios, } \\
\text { psicoanálisis de Carl Gustav Jung, } \\
\text { epistemología de Gaston Bachelard. }\end{array}$ & Francia \\
\hline $\begin{array}{l}\text { Lev Vigostky (1896 } \\
-1934)\end{array}$ & $\begin{array}{l}\text { Enseñanza }- \\
\text { aprendizaje }\end{array}$ & $\begin{array}{l}\text { Constructivismo socio - cultural, } \\
\text { psicología histórico - cultural. }\end{array}$ & $\begin{array}{l}\text { Antigua Unión } \\
\text { Soviética }\end{array}$ \\
\hline Umberto Eco (1932) & Signo & Semiótica & Italia \\
\hline $\begin{array}{l}\text { David Ausubel (1918 } \\
-2008)\end{array}$ & $\begin{array}{l}\text { Aprendizaje } \\
\text { significativo }\end{array}$ & Psicopedagogía cognitiva & Estados Unidos \\
\hline
\end{tabular}




\begin{tabular}{|c|c|c|c|}
\hline $\begin{array}{l}\text { Jürgen Habermas } \\
\text { (1929) }\end{array}$ & $\begin{array}{l}\text { Acción } \\
\text { comunicativa, } \\
\text { ciudadanía } \\
\end{array}$ & Escuela de Frankfurt, teoría crítica & Alemania \\
\hline $\begin{array}{l}\text { Niklas Luhmann } \\
(1927-1998)\end{array}$ & Comunicación & $\begin{array}{l}\text { Funcional - estructuralismo, teoría } \\
\text { de sistemas, cibernética de segundo } \\
\text { orden }\end{array}$ & Alemania \\
\hline $\begin{array}{l}\text { Gregory Bateson } \\
(1904-1980)\end{array}$ & Comunicación & $\begin{array}{l}\text { Escuela de Palo Alto, California, } \\
\text { Estados Unidos; cibernética }\end{array}$ & $\begin{array}{l}\text { Reino Unido - } \\
\text { Estados Unidos }\end{array}$ \\
\hline $\begin{array}{l}\text { Armando Silva } \\
\text { (1948) }\end{array}$ & $\begin{array}{l}\text { Imaginarios } \\
\text { Urbanos }\end{array}$ & $\begin{array}{l}\text { Imaginarios urbanos. Se basó en } \\
\text { autores como Jacques Derrida, Henrry } \\
\text { Lefevre, Sigmund Freud, Charles } \\
\text { Sanders Peirce, entre otros. }\end{array}$ & Colombia \\
\hline $\begin{array}{l}\text { Néstor García } \\
\text { Canclini } \\
(1938)\end{array}$ & $\begin{array}{l}\text { Consumo } \\
\text { cultural, proceso } \\
\text { de hibridación } \\
\text { cultural }\end{array}$ & Consumo cultural & $\begin{array}{l}\text { Argentina - } \\
\text { México. }\end{array}$ \\
\hline $\begin{array}{l}\text { Guillermo Orozco } \\
\text { Gómez (1954) }\end{array}$ & Recepción & \begin{tabular}{|lll}
$\begin{array}{l}\text { Recepción activa y múltiples } \\
\text { mediaciones }\end{array}$ & y \\
\end{tabular} & México \\
\hline $\begin{array}{l}\text { Pierre Lévy } \\
(1956)\end{array}$ & $\begin{array}{l}\text { Cibercultura - } \\
\text { ciberespacio }\end{array}$ & $\begin{array}{l}\text { Antropología de la relación hombre - } \\
\text { máquina }\end{array}$ & Túnez - Canadá \\
\hline Alejandro Piscitelli & $\begin{array}{l}\text { Cibercultura - } \\
\text { ciberespacio }\end{array}$ & $\begin{array}{l}\text { Antropología de la relación hombre - } \\
\text { máquina }\end{array}$ & Argentina \\
\hline Carlos Scolari & $\begin{array}{l}\text { Narrativas } \\
\text { transmedia }\end{array}$ & $\begin{array}{l}\text { Antropología de la relación hombre } \\
\text { máquina. Planteamientos de Umberto } \\
\text { Eco y Algirdas Greimas. }\end{array}$ & $\begin{array}{l}\text { Argentina - } \\
\text { España. }\end{array}$ \\
\hline
\end{tabular}

Fuente: elaboración propia

Las diferentes perspectivas teóricas seleccionadas para la realización de los trabajos de investigación de los estudiantes de la Maestría en Comunicación Educativa, dan información sobre el esquema observacional construido desde el aspecto teórico. Se pueden plantear tres tendencias que dan cuenta del mencionado esquema: a) El enfoque constructivista, b) La concepción de los fenómenos sociales como mundos posibles, c) La problematización de los fenómenos comunicativos y educativos desde una perspectiva semiótica $\mathrm{y}$ antropológica.

El enfoque constructivista mencionado, no hace referencia a una teoría particular, sino al paradigma constructivista en calidad de corriente de pensamiento que ha tenido un influjo importante en las diversas disciplinas con constituyen a las Ciencias Sociales y Humanas. Si bien existe una variedad considerable deenfoquesdel constructivismo como paradigma epistemológico: 
constructivismo radical (Paul Watzlawick 1980), constructivismo genético (Jean Piaget 1940), Constructivismo socio cultural (Lev Vigostky 1930), Constructivismo Sistémico (Niklas Luhmann 1980); podemos afirmar que su premisa fundamental radica en reconocer que la realidad es un ingenio construido por los observadores. Esto da índices importantes para comprender de qué manera se abordan los diferentes fenómenos educativos y comunicativos al interior de la Maestría en Comunicación Educativa.

En concomitancia con lo anteriormente dicho, los fenómenos educativos y comunicativos no se asumen desde perspectivas normativas que indiquen de qué manera tienen que ser los fenómenos; estos se abordan como procesos emergentes que pueden tener múltiples manifestaciones. En la perspectiva trazada por Gregory Bateson (1972), no nos quedamos en la lógica de describir los elementos que integran un fenómeno, sino en distinguir y construir relaciones entre los diversos elementos que los constituyen de tal manera que se pueda alumbrar nuevo conocimiento.

Como se ha planteado en la introducción de este libro, si bien la comunicación educativa como campo de conocimiento emergente es objeto de diversos abordajes, en el caso de la Maestría en Comunicación Educativa, se ha optado por un enfoque semiótico y antropológico para comprender la complejidad de los fenómenos educativos y comunicativos; este enfoque es coherente con la perspectiva constructivista y la distinción de mundos posibles en los diferentes fenómenos.

\section{Esquema de Observación 2. Perspectivas metodológicas implicadas}

Como bien se pudo distinguir en la lectura de este libro, la perspectiva metodológica que predomina para la realización de los trabajos de investigación por parte de los estudiantes de la Maestría en Comunicación Educativa, se fundamenta en el enfoque cualitativo y hermenéutico.

Es importante aclarar, que tal decisión metodológica no es consecuencia de algún tipo de perfil definido a priori; es el resultado de la comprensión que se tiene de las implicaciones que traen consigo el constructivismo, los 
mundos posibles y la perspectiva semiótico - antropológica como esquema de observación teórico.

\section{Esquema de observación 3. Objetos de estudio seleccionados}

Los dos esquemas de observación anteriormente referidos, tienen implicaciones en cuanto a los objetos de estudio seleccionados para llevar a cabo el proceso de investigación en el marco de la Maestría en Comunicación Educativa. A continuación haremos referencia a ellos:

- La relación enseñanza - aprendizaje como un proceso comunicativo.

- Imaginarios urbanos.

- Recepción de contenidos televisivos.

- Lenguaje.

- Culturas juveniles.

- Imaginarios de salud.

- La ciudad.

- Video juegos y educación.

- Antropología de las pantallas.

- Cibercultura y ciberespacio.

Se puede afirmar que existe una relación de recursividad entre las perspectivas teóricas y los objetos de estudio seleccionados para llevar a cabo los procesos de investigación en la Maestría en Comunicación Educativa. Esto quiere decir que en ocasiones las perspectivas teóricas definidas, dan pistas acerca de los objetos de estudio que se pueden seleccionar; mientras que en otras ocasiones son los objetos de estudio los que llevan a decidir por una u otra perspectiva teórica. En todo caso, lo que siempre se procura es que haya coherencia lógica entre las decisiones teóricas, las implicaciones metodológicas y la manera en que se interpretan los objetos de estudio seleccionados. 


\section{Asesores}

\section{Olga Lucía Bedoya:}

Doctora en Ciencias Políticas por la Universidad de Santiago de Compostela.

\section{Victoria Eugenia Valencia López:}

Doctora en Ciencias de la Educación, área Pensamiento Educativo y Comunicación, por la Universidad Tecnológica de Pereira.

\section{Yhon Jairo Acosta Barajas:}

Candidato a Doctor en Ciencias de la Educación, área Pensamiento Educativo y Comunicación, por la Universidad Tecnológica de Pereira.

\section{Julián David Vélez Carvajal:}

Candidato a Doctor en Ciencias de la Educación, área Pensamiento Educativo y Comunicación por la Universidad Tecnológica de Pereira.

\section{Álvaro Acevedo Tarazona:}

Doctor en Ciencias de la Educación por la Universidad Pedagógica y Tecnológica de Colombia.

\section{Luz Ángela Cardona Arce:}

Magíster en Comunicación Educativa por la Universidad Tecnológica de Pereira.

\section{Carlos Emilio García Duque:}

Doctor en Filosofía de la Universidad de Florida.

\section{Omar Iván Trejos Buriticá:}

Doctor en Ciencias de la Educación, área Pensamiento Educativo y Comunicación, por la Universidad Tecnológica de Pereira.

\section{María Paola Bermúdez:}

Magíster en Comunicación Educativa por la Universidad Tecnológica de Pereira. 


\section{Bibliografía}

- Aparici, R. (Comp) (2010). Educomunicación: más allá del 2.0. España: Gedisa. 2010.

- Arango, Bustamante, D. (2011). Imaginarios de una Medellín en blanco y negro ciudadanos de hoy leyendo a los ciudadanos de ayer: fotografías del centro de Medellín. (Tesis inédita de Maestría). Universidad Tecnológica de Pereira.

- Bateson, G. (1972). Pasos hacia una ecología de la mente: aproximación revolucionaria a la autocomprensión del hombre. Argentina: Lumen.

- Bedoya, O., Castiblanco, A., Patiño, G., Maldonado, F. y Zuluaga, V. (1999). Imaginario femenino y ciudad Pereira y su evocación de mujer. Pereira. Tercer Mundo Editores.

- Bedoya, O. y Castiblanco, A. (2002). Modos de Ver: Los sentidos de la comunicación educativa (1990 -2002). Pereira. Editorial Papiro.

- Bedoya, O., Castiblanco, A., y Jaramillo N. (2004). Paradoja de la ciudadanía en Pereira: entre los ciudadanos jurídicos y los itinerantes (20002003). Universidad Tecnológica de Pereira, Pereira. Postergraph S.A.

- Bedoya, O., Castiblanco, A., Jaramillo N. y Verón O. (2008). Memoria y ciudad: Pereira post-sísmica 2001-2006. Otras cartografías desde la percepción ciudadana. Universidad Tecnológica de Pereira, Pereira. Postergraph S.A.

- Bedoya, O. L. y Leal, C. (2008). Modos de Ver II: Los sentidos de la comunicación educativa 2002 - 2007. Pereira. Publiprint.

- Bedoya, O. L. y Bermúdez, M. (2007). Antropología del Megabús. Universidad Tecnológica de Pereira. Pereira. Postergraph S.A.

- Boden, M. (1991). La mente creativa: mitos y mecanismos. España: Gedisa.

- Botero Escobar, N. (2011). Cibernautas y la Medellín imaginada: entre el ethos y el tanathos. (Tesis inédita de Maestría). Universidad Tecnológica de Pereira. 
- Botero Girón, C. (2011). Discusión de la metáfora como terceridad en los procesos de comunicación de la ciencia, la tecnología y la innovación en la Universidad Tecnológica de Pereira. (Tesis inédita de Maestría). Universidad Tecnológica de Pereira.

- Cardona Cano, C y Álvarez Moreno, M. (2014). Medellín imaginada desde la televisión. Los imaginarios en la serie de televisión: Muchachos a lo bien. (Tesis inédita de Maestría). Universidad Tecnológica de Pereira.

- Calle Álvarez, D. (2011). Medellín crónicas: una mirada desde sus imaginarios urbanos. (Tesis inédita de Maestría). Universidad Tecnológica de Pereira.

- Castaño Galvis, C. (2014). Pereira, transición de gran ciudad a desarrollo y progreso. (Tesis inédita de Maestría). Universidad Tecnológica de Pereira.

- Castaño Rico, S. (2012). Imaginarios religiosos de Medellín con respecto a las imágenes presentes en las familias. (Tesis inédita de maestría). Universidad Tecnológica de Pereira.

- Concha Ocampo, E. (2014). Macroproyecto Pereira imaginada: croquis ciudadanos. Caso imaginarios urbanos con aroma de café: puente de Pereira entre el Éxito y el Hotel Camino Real. (Tesis inédita de Maestría). Universidad Tecnológica de Pereira.

- Córdoba González, S (2011). Medellín en subjetiva: visión de los ciber/ youtube/anos. Estudio de caso: contribución a los archivos urbanos. (Tesis inédita de Maestría). Universidad Tecnológica de Pereira.

- Cruz Arizmendi, G. (2012). El mundo perdido de la realidad. (Tesis inédita de Maestría). Universidad Tecnológica de Pereira.

- García, L. (2011). De lo azul a lo cálido y popular. (Tesis inédita de Maestría). Universidad Tecnológica de Pereira.

- García Loaiza, E. (2009). Análisis de la competencia televisiva en la interacción maestro - estudiante de básica secundaria y su impacto en la audiencia adolescente televisiva. (Tesis inédita de Maestría). Universidad Tecnológica de Pereira.

- García, N. (1995). Consumidores y ciudadanos: conflictos multiculturales de la globalización. México: Editorial Grijalbo. 
- García, N. (2004). Culturas híbridas: estrategias para entrar y salir de la modernidad. España: Paidos.

- Gil Correa, D. (2015). Consideraciones sobre los procesos de recepción en estudiantes de grado décimo del Instituto Agropecuario Veracruz de Santa Rosa de Cabal, Risaralda. (Tesis inédita de Maestría). Universidad Tecnológica de Pereira.

- Gómez, Rubiano, C. (2011). Pereira imaginada fase II 2009-2014 ¿La ciudad del deseo o la ciudad del corazón partió? (Tesis inédita de Maestría). Universidad Tecnológica de Pereira.

- Herrera Díaz, N. (2012). Imaginarios urbanos en la literatura: las novelas como fuente de reconstrucción de los imaginarios sobre Medellín. Caso: La ciudad de todos los adioses de César Alzate Vargas, El dedo índice de Mao de Juan Diego Mejía y Basura de Héctor Abad Faciolince. (Tesis inédita de Maestría). Universidad Tecnológica de Pereira.

- Hoyos Morales, J. (2010). Identificación de categorías toulminianas en clase de filosofía a nivel de educación media con nuevas tecnologías. (Tesis inédita de Maestría). Universidad Tecnológica de Pereira.

- Hurtado, Tabares, L. (2011). Construcción de ciudad desde la temporalidad plural en transporte público. Pereira imaginada 2009 - 2014. (Tesis inédita de Maestría). Universidad Tecnológica de Pereira.

- Lopera Agudelo, A. (2011). Imaginarios urbanos (de ciudad), el cine de ficción realizado en Medellín de 2000 a 2010. (Tesis inédita de Maestría). Universidad Tecnológica de Pereira.

- López Montoya, M y Vega González, F. (2012). Emergencia de la función de innovación en la universidad: el proceso de la Universidad Tecnológica de Pereira. (Tesis inédita de Maestría). Universidad Tecnológica de Pereira.

- Lévy, P. (2004). Inteligencia colectiva. Por una antropología del ciberespacio. Washington: Organización Panamericana de la Salud.

- Lévy, P. (2007). Cibercultura: informe al consejo de Europa. España: Anthropos.

- Luhmann, N. (1995). La realidad de los medios de masas. España: Anthropos. 1995. 
- Luhmann, N. (1998). Complejidad y modernidad: de la unidad a la diferencia. Madrid: Editorial Trotta.

- Luhmann, N. (2005). El arte de la sociedad. México: Editorial Herder.

- Llamosa Pérez, V. (2011). Modelos de consumo. El caso de las mujeres protagonistas de la telenovela las muñecas de la mafia. (Tesis inédita de Maestría). Universidad Tecnológica de Pereira.

- Muñoz Guzmán, C. (2014). El paisaje cultural cafetero: una encrucijada entre la sostenibilidad y un futuro amenazado. (Tesis inédita de Maestría). Universidad Tecnológica de Pereira.

- Muñoz Rincón, D. (2012). Medellín, un recorrido sobre lo oculto en crónicas y reportajes. (Tesis inédita de Maestría). Universidad Tecnológica de Pereira.

- Ospina Lozada, M. (2011). Pereira imaginada 2009 - 2014. Rutinas ciudadanas: una mirada comunicativa de los imaginarios urbanos en el espacio virtual de los jóvenes entre 12 y 16 años de la Institución Educativa Ciudadela Cuba. (Tesis inédita de Maestría). Universidad Tecnológica de Pereira.

- Orozco, G. (2001). Televisión, audiencias y educación. Bogotá: Grupo Editorial Norma.

- Orozco, G. (2010). Entre pantallas: nuevos roles comunicativos y educativos de los ciudadanos. En: Educomunicación: más allá del 2.0. España: Gedisa.

- Orozco Giraldo, C. (2011). Vitrineando la semiótica de los imaginarios urbanos de la ciudadela cuba. (Tesis inédita de Maestría). Universidad Tecnológica de Pereira.

- Perdomo Rodas, A. (2014). Emprendedor = comunicador de ideas: imaginarios visibilizados en los emprendedores de Parquesoft Pereira. (Tesis inédita de Maestría). Universidad Tecnológica de Pereira.

- Piedrahita Bedoya, F. (2011). La radio y los imaginarios urbanos en Medellín: de lo semiótico y lo ideológico a la configuración del imaginario social del paisa. Caso de las noticias de Radio Paisa. (Tesis inédita de Maestría). Universidad Tecnológica de Pereira. 
- Ramos Olaya, M. (2012). Cuerpo imaginado: objeto de ensoñaciones y deseos. (Tesis inédita de Maestría). Universidad Tecnológica de Pereira.

- Restrepo, M. (1993). Ser, signo, interpretante. Filosofía de la representación de Charles Sanders Peirce. Bogotá: Significantes de papel.

- Restrepo, M. (2010). Representación, relación tríadica en el pensamiento de Charles S. Peirce. Bogotá: Universidad Nacional de Colombia.

- Rojas Hurtado, A. Jiménez, L. Peña Osorio, D. (2014). Macroproyecto: validación de propuesta educativa con investigación basada en diseño. (Tesis inédita de Maestría). Universidad Tecnológica de Pereira.

- Sánchez Muñoz, C. (2009). La palabra de la radio al aula: formación de maestros que atienden estudiantes con discapacidad visual en las aulas integradoras. El caso de la Institución Educativa Pablo Emilio Cardona. (Tesis inédita de Maestría). Universidad Tecnológica de Pereira.

- Schumpeter, J. (1943). Puede sobrevivir el capitalismo. E.E.U.U: Capitán Swing Editorial.

- Silva, T. A. (1992). Imaginarios urbanos. Bogotá: Editorial Tercer Mundo.

- Silva, T. A. (2003). Bogotá imaginada. Bogotá: Taurus.

- Silva, T. A. (2004). Imaginarios urbanos: hacia el desarrollo de un urbanismo desde los ciudadanos. Bogotá: Edición del Convenio Andrés Bello.

- Silva, T. A. (2007). Imaginarios urbanos en América Latina: urbanismos ciudadanos. Barcelona: Fundación Antoni Tápies.

- Thompson, J. (1998). Los media y la modernidad. Una teoría de los medios de comunicación. España: Paidós.

- Vásquez, Murillo, R. (2011). Marcas Ciudadanas: Una mirada al gusto de los pereiranos. (Tesis inédita de Maestría). Universidad Tecnológica de Pereira.

- Velásquez Bonilla, N. (2012). Imaginarios de ciudad saludable. (Tesis inédita de Maestría). Universidad Tecnológica de Pereira. 


\section{Los autores}

Olga Lucía Bedoya: PhD. En Ciencias Políticas de la Universidad de Salamanca, España. Magíster en Lingüística y antropóloga por la Universidad de Antioquia. Directora del Doctorado en Ciencias de la Educación, área Pensamiento Educativo y Comunicación y de la Maestría en Comunicación Educativa de la Universidad Tecnológica de Pereira.

Julián David Vélez Carvajal: Candidato a Doctor en Ciencias de la Educación, área Pensamiento Educativo y Comunicación. Magíster en Comunicación Educativa y Licenciado en Etnoeducación y Desarrollo Comunitario por la Universidad Tecnológica de Pereira. Docente transitorio de la Facultad de Ciencias de la Educación y de la Maestría en Comunicación Educativa de la Universidad Tecnológica de Pereira.

Victoria Eugenia Valencia López: PhD. En Ciencias de la Educación, área Pensamiento Educativo y Comunicación. Licenciada en Etnoeducación y Desarrollo Comunitario. Docente del magisterio colombiano e integrante del grupo de investigación en Comunicación Educativa de la Maestría con el mismo nombre. 
"Los autores de libro sostienen que la comunicación educativa es un campo de estudios de carácter emergente y para argumentarlo convocan a considerar a la comunicación más allá de los medios y a la educación más allá del aula. Al mismo tiempo invita a abordar esta interrelación a partir de las posibilidades que abren las proximidades entre la semiótica, la antropología y la perspectiva sistémica, desde varios autores de diversas nacionalidades. Mediante la estrategia de "observación de segundo orden", propuesta por Niklas Luhmann, se identifican tres tipos de lo que en esta perspectiva son "medios": los referentes teóricos, las metodologías empleadas y los objetos de estudio. El contenido del libro constituye un sustento académico sólido para el punto de vista planteado. Este libro es de carácter no solo compilatorio sino sobre todo analítico que tiene la virtud de reflexionar sobre la producción investigativa de la Maestría en Comunicación Educativa de la Universidad Tecnológica de Pereira. De esta manera se trasciende la labor profesionalizante y se aborda una dimensión metacognitiva, sistematizadora del pensamiento producido en dicho programa académico. Esfuerzos como este contribuyen a cualificar a la educación postgradual en nuestro país".

Jurado Evaluador 
Inspirados en los planteamientos teóricos del alemán Niklas Luhmann, los autores de este libro realizan un abordaje analítico y relacional de los diferentes trabajos de grado realizados por los estudiantes de la Maestría en Comunicación Educativa de la Universidad Tecnológica de Pereira. Tanto las perspectivas teóricas, como los enfoques metodológicos y los diferentes objetos de estudio abordados en dichos trabajos, se constituyeron en las categorías a partir de las cuales se realizó el proceso de observación.

Los resultados obtenidos se contrastaron con el estado de la cuestión del área de conocimiento denominada "comunicación educativa", con el propósito de establecer el aporte que, desde la maestría en mención, se realiza a este campo del saber. De esta manera, el presente libro no sólo contiene una hermenéutica de los trabajos abordados, sino que evidencia la manera en la que la maestría en Comunicación Educativa y su grupo de investigación, aportan a la discusión acerca de la relación entre comunicación y educación.
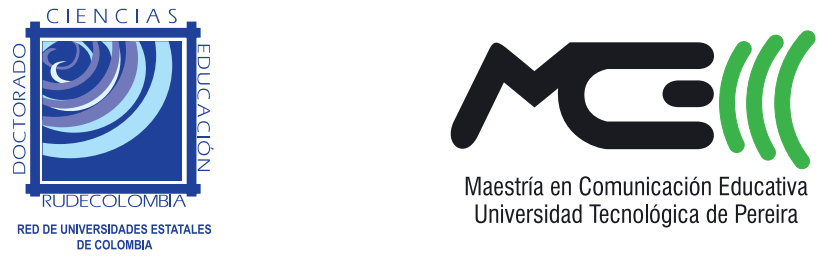